\title{
HYDROLOGY OF THE SOUTHEASTERN COASTAL PLAIN AQUIFER SYSTEM IN SOUTH CAROLINA AND PARTS OF GEORGIA AND NORTH CAROLINA
}

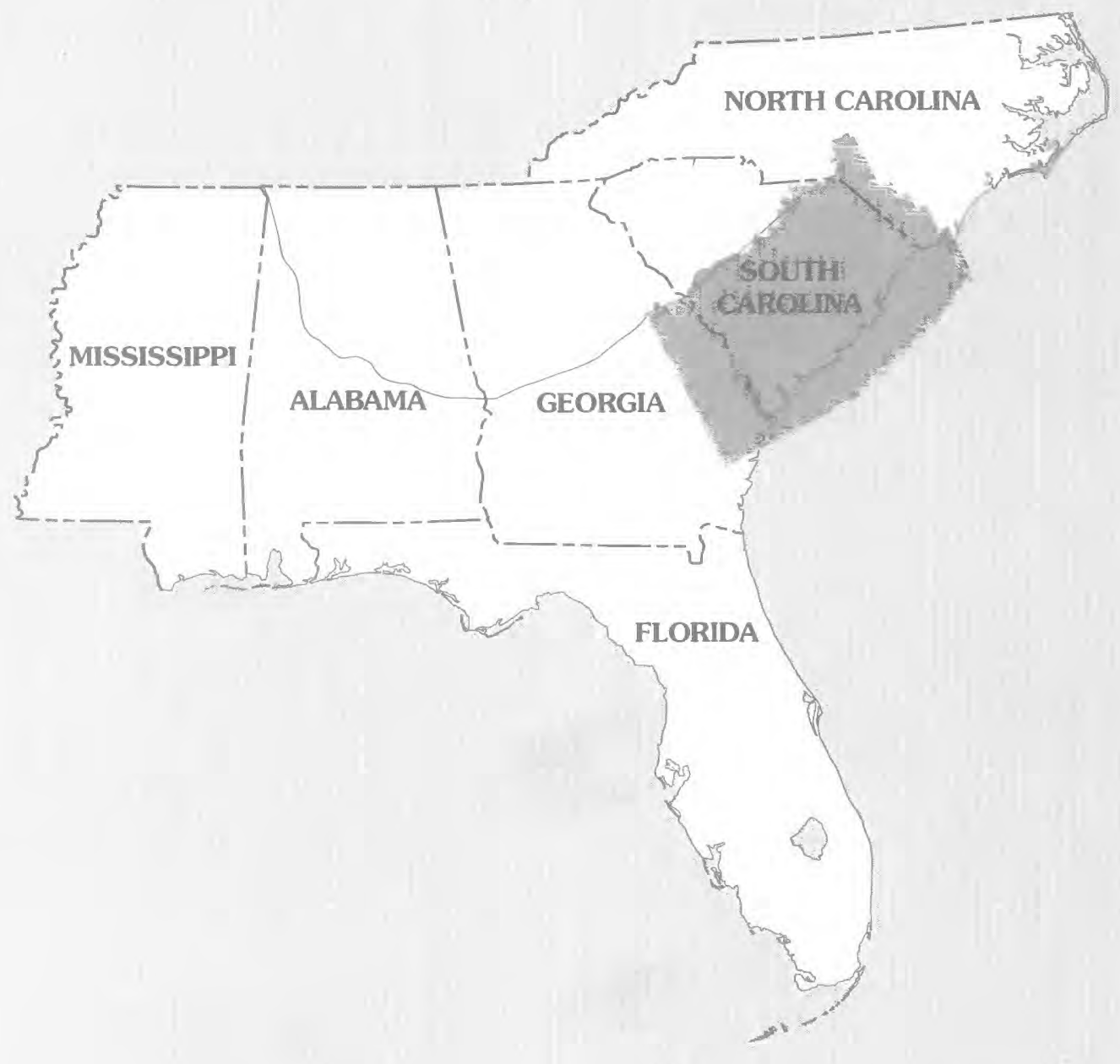

U.S. GEOLOGICAL SURVEY PROFESSIONAL PAPER 1410-E 


\section{AVAILABILITY OF BOOKS AND MAPS OF THE U.S. GEOLOGICAL SURVEY}

Instructions on ordering publications of the U.S. Geological Survey, along with prices of the last offerings, are given in the currentyear issues of the monthly catalog "New Publications of the U.S. Geological Survey." Prices of available U.S. Geological Survey publications released prior to the current year are listed in the most recent annual "Price and Availability List." Publications that may be listed in various U.S. Geological Survey catalogs (see back inside cover) but not listed in the most recent annual "Price and Availability List" may be no longer available.

Order U.S. Geological Survey publications by mail or over the counter from the offices given below.

\section{BY MAIL}

\section{Books}

Professional Papers, Bulletins, Water-Supply Papers, Techniques of Water-Resources Investigations, Circulars, publications of general interest (such as leaflets, pamphlets, booklets), single copies of Preliminary Determination of Epicenters, and some miscellaneous reports, including some of the foregoing series that have gone out of print at the Superintendent of Documents, are obtainable by mail from

\section{U.S. Geological Survey, Information Services \\ Box 25286, Federal Center, Denver, CO 80225}

Subscriptions to Preliminary Determination of Epicenters can be obtained ONLY from the

\section{Superintendent of Documents Government Printing Office Washington, DC 20402} Documents.)

(Check or money order must be payable to Superintendent of

\section{Maps}

For maps, address mail orders to

U.S. Geological Survey, Information Services Box 25286, Federal Center, Denver, CO 80225

\section{OVER THE COUNTER}

\section{Books and Maps}

Books and maps of the U.S. Geological Survey are available over the counter at the following U.S. Geological Survey Earth Science Information Centers (ESIC's), all of which are authorized agents of the Superintendent of Documents:

- ANCHORAGE, Alaska-Rm. 101, 4230 University Dr.

- LAKEWOOD, Colorado-Federal Center, Bldg. 810

- MENLO PARK, California-Bldg. 3, Rm. 3128, 345 Middlefield Rd.

- RESTON, Virginia-USGS National Center, Rm. 1C402, 12201 Sunrise Valley Dr.

- SALT LAKE CITY, Utah-Federal Bldg., Rm. 8105, 125 South State St.

- SPOKANE, Washington-U.S. Post Office Bldg., Rm. 135, West 904 Riverside Ave.

- WASHINGTON, D.C.-Main Interior Bldg., Rm. 2650, 18th and C Sts., NW.

\section{Maps Only}

Maps may be purchased over the counter at the following U.S. Geological Survey office:

- ROLLA, Missouri-1400 Independence Rd. 
Hydrology of the

Southeastern Coastal Plain Aquifer System in

South Carolina and Parts of Georgia and North Carolina

By WALTER R. AUCOTT

REGIONAL AQUIFER-SYSTEM ANALYSIS-

SOUTHEASTERN COASTAL PLAIN

U.S. GEOLOGICAL SURVEY PROFESSIONAL PAPER 1410-E

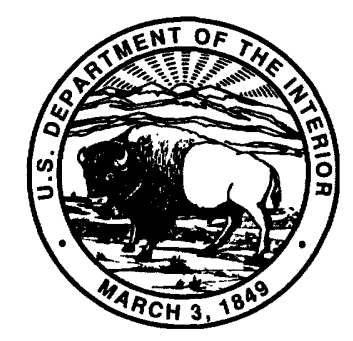




\title{
U.S. DEPARTMENT OF THE INTERIOR \\ BRUCE BABBITT, Secretary
}

\author{
U.S. GEOLOGICAL SURVEY \\ Gordon P. Eaton, Director
}

Any use of trade, product, or firm names in this publication is for descriptive purposes only and does not imply endorsement by the U.S. Government.

Library of Congress Cataloging in Publication Data

Aucott, Walter R.

Hydrology of the Southeastern Coastal Plain aquifer system in South Carolina and parts of Georgia and North Carolina / by Walter R. Aucott

p. cm. - (Regional aquifers-system analysis-Southeastern Coastal Plain) (U.S. Geological Survey professional paper : 1410-E)

Includes bibliographical references.

1. Aquifers-Southern States. I. Title. II. Series. III. Series: U.S. Geological Survey professional paper : 1410-E

GB1199.3.S68A83 1996

$551.49^{\circ} 0975$

For sale by the U.S. Geological Survey, Branch of Information Services, Box 25286, Federal Center, Denver, CO 80225. 


\section{FOREWORD}

\section{THE REGIONAL AQUIFER-SYSTEM ANALYSIS PROGRAM}

The Regional Aquifer-System Analysis (RASA) Program represents a systematic effort to study a number of the Nation's most important aquifer systems, which, in aggregate, underlie much of the country and which represent an important component of the Nation's total water supply. In general, the boundaries of these studies are identified by the hydrologic extent of each system and, accordingly, transcend the political subdivisions to which investigations have often arbitrarily been limited in the past. The broad objective for each study is to assemble geologic, hydrologic, and geochemical information; to analyze and develop an understanding of the system; and to develop predictive capabilities that will contribute to the effective management of the system. The use of computer simulation is an important element of the RASA studies to develop an understanding of the natural, undisturbed hydrologic system and the changes brought about in it by human activities and to provide a means of predicting the regional effects of future pumping or other stresses.

The final interpretive results of the RASA Program are presented in a series of U.S. Geological Survey Professional Papers that describe the geology, hydrology, and geochemistry of each regional aquifer system. Each study within the RASA Program is assigned a single Professional Paper number beginning with Professional Paper 1400.

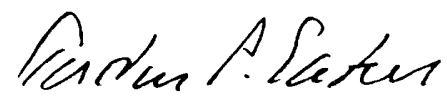

Gordon P. Eaton Director 



\section{CONTENTS}

Foreword

Abstract.

Introduction.

Purpose and Scope.............................................

Description of the Study Area

South Carolina Physiography

Rivers

Previous Investigations

General Geohydrology

Geologic Structure

Geohydrologic Unit

Aquifers and Aquifer Systems

Surficial Aquifer.

Floridan Aquifer System.

Tertiary Sand Aquifer

Black Creek Aquifer

Middendorf Aquifer.

Cape Fear Aquifer
Page

III

E1

1

2
General Geohydrology-Continued Geohydrologic Units-Continued

Confining Units.

Page

E19

Ground-Water Flow System ........................................ 20

Stratification of Flow System ..................................... 20

Predevelopment Flow System.................................. 21

Changes in the Flow System as a Result of Development.. 29

Water Quality and General Geochemistry ........................ 37

Simulation of the Ground-Water Flow System .................... 41

Approach ................................................ 41

Model Inputs ..................................................... 42

Model Boundaries ............................................ 44

Model Calibration ............................................... 49

Sensitivity Testing............................................ 56

Model-Derived Hydrologic Characteristics ........................ 56

Simulated 1982 Water Budget....................................... $\quad 72$

Summary and Conclusions .............................................. 79

Selected References ................................................. 80

\section{ILLUSTRATIONS}

Figures 1-4. Maps showing-

1. Location of the study area

2. Relation among overlapping models of the Coastal Plain aquifer systems in South Carolina, Georgia, and North Carolina

3. Average annual precipitation and runoff in South Carolina and average monthly data for selected sites, $1951-80$.

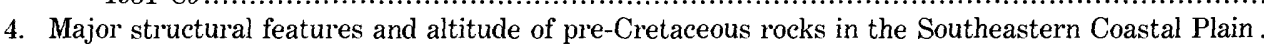

5. Schematic diagram of regional geohydrologic units and selected rock-stratigraphic units in the Southeastern

Coastal Plain

6. Map showing location of geohydrologic sections.....

7-12. Generalized geohydrologic section-

7. $A-A^{\prime}$

8. $A^{\prime}-A^{\prime \prime}$

9. $B-B^{\prime}$

10. $B^{\prime}-B^{\prime \prime}$

11. $C-C^{\prime}$.

12. $D-D^{\prime}$

13. Map showing areal extent of Coastal Plain aquifers in South Carolina...

14. Diagrammatic section of a stratified ground-water flow system.....

15-18. Maps showing the estimated predevelopment potentiometric surface of the-

15. Floridan aquifer system and the Tertiary sand aquifer.

16. Black Creek aquifer

17. Middendorf aquifer

18. Cape Fear aquifer.

19. Map showing drainage basins of selected upper Coastal Plain rivers and data-collection sites..

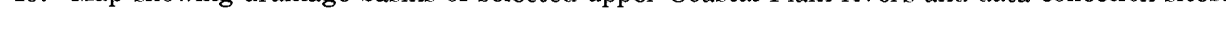


20. Map showing locations of ground-water withdrawals greater than 2 million gallons per day in 1980 in the South Carolina Coastal Plain and vicinity.....

21-23. Maps showing the potentiometric surface, November 1982 , of the-
21. Floridan aquifer system and the Tertiary sand aquifer.............

22. Black Creek aquifer

23. Middendorf aquifer

24-26. Maps showing declines in the potentiometric surface between predevelopment and November 1982 for the-

24. Floridan aquifer system and the Tertiary sand aquifer

25. Black Creek aquifer

26. Middendorf aquifer

27. Graph showing water-level declines for selected wells in the Middendorf aquifer near Florence, S.C.

28-34. Maps showing-

28. Dominant chemical constituents in water from the Middendorf aquifer

29. Concentrations of dissolved solids in water from the Middendorf aquifer

30. Dominant chemical constituents in water from the Black Creek aquifer.....

31. Concentrations of dissolved solids in water from the Black Creek aquifer ....

32. Dominant chemical constituents in water from the Floridan aquifer system and the Tertiary sand aquifer........

33. Concentrations of dissolved chloride in water from the Middendorf aquifer

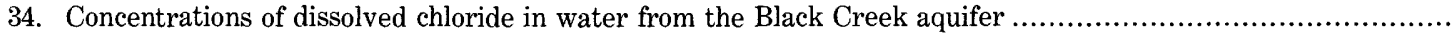

35. Diagrammatic geohydrologic section across the South Carolina Coastal Plain

36. Diagram showing conceptualization of model layers

37. Maps showing model grid and specified boundary conditions and locations of river nodes

38-40. Maps showing observed and simulated water-level declines between predevelopment and 1982 for the-

38. Floridan aquifer system and the Tertiary sand aquifer....

39. Black Creek aquifer .

40. Middendorf aquifer

41. Hydrographs of observed and simulated water levels near Florence, S.C.

42. Hydrographs of observed and simulated water levels near Conway and Fairfax, S.C.

43. Graph showing sensitivity of the calibrated predevelopment and transient (1982) models to changes in input parameters as measured by changes in average absolute head residual per grid block

aph showing sensitivity of the calibrated predevelopment and transient (1982) models to changes in input parameters as measured by changes in total simulated riverflow.

45-48. Maps showing simulated and field values of transmissivity for the-

45. Floridan aquifer system and the Tertiary sand aquifer

46. Black Creek aquifer

47. Middendorf aquifer

48. Cape Fear aquifer.

49-52. Maps showing the simulated leakance coefficient of the confining unit between the -

49. Surficial aquifer and underlying units.

50. Floridan aquifer system-Tertiary sand aquifer and the Black Creek aquifer

51. Black Creek aquifer and the Middendorf aquifer

52. Middendorf aquifer and the Cape Fear aquifer

53. Map showing the simulated distribution of storage coefficient.

54. Map showing simulated average recharge to and discharge from the deep ground-water flow system prior to development. ....

55-58. Maps showing the simulated November 1982 potentiometric surface of the -

55. Floridan aquifer system and the Tertiary sand aquifer

56. Black Creek aquifer

57. Middendorf aquifer

58. Cape Fear aquifer.

59. Diagram summarizing the simulated water budget for the deep flow system, November 1982.

60. Diagram summarizing the change in simulated water budget for the deep flow system between predevelopment and November 1982. 


\section{TABLES}

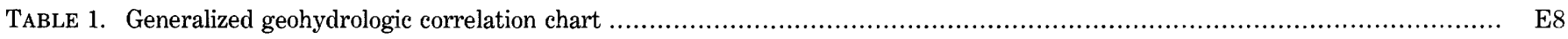

2. Low-flow characteristies of selected Coastal Plain streams in South Carolina ................................................ 26

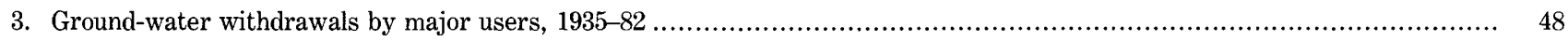

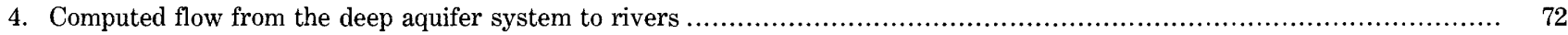

5. Observed and simulated flow from the deep aquifer system to rivers prior to development and in November 1982 and net change

\section{CONVERSION FACTORS AND VERTICAL DATUM}

\begin{tabular}{rll}
\hline Multiply & \multicolumn{1}{c}{ By } & To obtain \\
inch (in.) & 25.4 & millimeter \\
inch per year (in/yr) & 25.4 & millimeter per year \\
foot (ft) & 0.3048 & meter \\
mile $(\mathrm{mi})$ & 1.609 & kilometer \\
square mile $\left(\mathrm{mi}^{2}\right)$ & 2.590 & square kilometer \\
& & \\
million gallons per day $(\mathrm{Mgal} / \mathrm{d})$ & 0.04381 & cubic meter per second \\
foot per mile $\left(\mathrm{ft} / \mathrm{mi}^{2}\right)$ & 0.1894 & meter per kilometer \\
foot per day $(\mathrm{ft} / \mathrm{d})$ & 0.3048 & meter per day \\
foot per day per foot $[(\mathrm{ft} / \mathrm{d}) / \mathrm{ft}]$ & 1.0 & meter per day per meter \\
foot squared per day $\left(\mathrm{ft}^{2} / \mathrm{d}\right)$ & 0.09290 & meter squared per day \\
cubic foot per second $\left(\mathrm{ft}^{3} / \mathrm{s}\right)$ & 0.02832 & cubic meter per second \\
cubic foot per second per square mile $\left[\left(\mathrm{ft}^{3} / \mathrm{s}\right) / \mathrm{mi}^{2}\right]$ & 0.01760 & cubic meter per second per square kilometer \\
\hline & &
\end{tabular}

Additional abbreviation:

$\mathrm{mg} / \mathrm{L}=$ milligram per liter

Temperature in degrees Fahrenheit $\left({ }^{\circ} \mathrm{F}\right)$ can be converted to degrees Celsius $\left({ }^{\circ} \mathrm{C}\right)$ as follows:

$$
{ }^{\circ} \mathrm{C}=5 / 9\left({ }^{\circ} \mathrm{F}-32\right)
$$

Sea level: In this report "sea level" refers to the National Geodetic Vertical Datum of 1929 (NGVD of 1929) - a geodetic datum derived from a general adjustment of the first-order level nets of both the United States and Canada, formerly called Sea Level Datum of 1929. 



\title{
HYDROLOGY OF THE SOUTHEASTERN COASTAL PLAIN AQUIFER SYSTEM IN SOUTH GAROLINA AND PARTS OF GEORGIA AND NORTH CAROLINA
}

\author{
By Walter R. Aucott
}

\begin{abstract}
The wedge of sediments present beneath the Coastal Plain of South Carolina and adjacent parts of Georgia and North Carolina consists of sand, silt, clay, and limestone. These strata have been subdivided into six regional aquifers: the surficial aquifer, the Floridan aquifer system, the Tertiary sand aquifer, the Black Creek aquifer, the Middendorf aquifer, and the Cape Fear aquifer. Intervening confining units separate the aquifers, except for the Floridan aquifer system and the Tertiary sand aquifer, which together function as a single hydrologic unit.

The quality of ground water from the Coastal Plain aquifers of South Carolina generally is acceptable for most uses in most areas. The water in most aquifers under most of the Coastal Plain contains low concentrations of dissolved solids (less than 500 milligrams per liter) and no dominant constituents in the recharge areas. Downgradient, the water is a calcium bicarbonate or sodium bicarbonate type throughout most of the Coastal Plain. Sodium-chloride-type water is present still farther downgradient, near the coast.

A quasi-three-dimensional, finite-difference digital ground-water flow model was constructed to simulate flow in the Coastal Plain aquifers prior to development. The model also was used to evaluate the hydraulic responses to pumping that have occurred up to November 1982. The model consisted of five layers and a 48 by 63 node grid with a uniform square grid cell of 4 miles on a side.

The Coastal Plain aquifers are recharged primarily by precipitation in their outcrop areas. Discharge is primarily as base flow to upper Coastal Plain rivers, to overlying aquifers by leakage through confining units, and to wells.

Total simulated flow in the deep ground-water system was 967 cubic feet per second at the end of the transient simulation (1982). Recharge to the deep flow system simulated by the model was 793 cubic feet per second in the study area in 1982. Simulated aquifer discharge to large rivers was 660 cubic feet per second. Discharge to smaller rivers was not simulated because of the scale of the model.

Changes resulting from ground-water pumping were significant as of 1982. The simulated water budget indicates that in 1982,249 cubic feet per second were discharged from the aquifer system by wells. This pumping was balanced by the following changes from predevelopment conditions: 110 cubic feet per second derived from storage, 67 cubic feet per second decrease in aquifer-to-river discharge, 44 cubic feet per second increase in net inflow from source-sinks, and a net increase in inflow of 28 cubic feet per second across boundaries. Head declines in the Black Creek and Middendorf aquifers have occurred throughout
\end{abstract}

much of the eastern part of the Coastal Plain of South Carolina as a result of pumping in the Myrtle Beach and Florence areas. Simulation indicates that the dominant sources of water for upper Coastal Plain pumping centers such as the city of Florence are decrease in flow to rivers in the upper Coastal Plain and water derived from storage. The dominant sources of water for pumping centers in the Myrtle Beach area are water derived from storage, leakage from overlying aquifers, and net increases in inflow across boundaries.

Transmissivity values used in the flow simulation range from less than 1,000 feet squared per day near the updip limit of most aquifers to about 30,000 feet squared per day in the Middendorf aquifer in the Savannah River Plant area. Vertical hydraulic conductivity values used in simulation of confining units range from about $6 \times 10^{-7}$ feet per day for the confining unit between the Middendorf and Black Creek aquifers in coastal areas to $3 \times 10^{-2}$ feet per day for most of the confining units near their updip limits. Storage coefficients used in transient simulations were 0.15 where unconfined conditions exist and 0.0005 where confined conditions exist.

\section{INTRODUCTION}

In 1978 the U.S. Geological Survey began a nationwide program to study the regional aquifers that provide a significant part of the country's water supply. This program is termed Regional Aquifer-System Analysis (RASA) and was discussed in detail by Sun (1986). The general objectives of the RASA studies are described in the Foreword. The Southeastern Coastal Plain aquifer system, which underlies an area of about 130,000 square miles $\left(\mathrm{mi}^{2}\right)$ in the Southeastern United States, was one of the regional aquifer systems chosen for study.

The Southeastern Coastal Plain aquifer system consists of clastic sediments of Cretaceous and Tertiary age in South Carolina, Georgia, Alabama, and Mississippi and adjacent areas of northern Florida and southeastern North Carolina. The aquifer system extends from the southwestern flank of the Cape Fear arch in North Carolina westward to the Mississippi embayment. The Southeastern Coastal Plain aquifer system is located 
among four adjacent regional aquifer systems: the Northern Atlantic Coastal Plain aquifer system to the northeast, the Mississippi embayment and coastal lowlands aquifer systems to the west, and the Floridan aquifer system to the south and southeast. The Floridan aquifer system overlies much of the Southeastern Coastal Plain aquifer system in Georgia and South Carolina.

\section{PURPOSE AND SCOPE}

This report summarizes the findings of the RASA study of the ground-water flow system of the Coastal Plain aquifers of South Carolina and adjacent parts of Georgia and North Carolina. It includes a description of the geohydrologic framework, the predevelopment and 1982 ground-water flow systems, general water-quality characteristics, and the results of ground-water flow simulations. This report is one of several chapters of U.S. Geological Survey Professional Paper 1410 that describe various aspects of the geology, hydrology, and geochemistry of the Southeastern Coastal Plain aquifer system.

The study area for this report encompasses the Coastal Plain of South Carolina and adjacent areas in Georgia, North Carolina, and the offshore areas bordering these States (fig. 1). It is bounded to the northwest by the inner margin of Coastal Plain sediments as marked by the Fall Line, which separates the Coastal Plain and Piedmont physiographic provinces. Adjoining areas in eastern Georgia and southeastern North Carolina were included in this study to describe adequately the hydrology of the Coastal Plain aquifer system in South Carolina, which is the principal focus of this report. The offshore area is bounded seaward by the postulated position of the freshwater-saltwater interface. The Coastal Plain sediments studied in this report are bounded below by consolidated pre-Cretaceous metamorphic, igneous, and sedimentary rocks.

This study overlaps a statewide RASA study to the southwest that is primarily concerned with the Georgia Coastal Plain (Faye and Mayer, in press) and one to the northeast that is primarily concerned with the North Carolina Coastal Plain (Giese and others, in press) (fig. 2 ). The aquifer system addressed by this study is partly within the area of the Floridan aquifer system RASA study (Miller, 1986). However, the Floridan aquifer system as defined by Miller (1986) has been expanded and redefined locally for purposes of this study.

This study used several analytical and digital modeling techniques to investigate the ground-water flow system. The analytical techniques included analysis of borehole geophysical logs and geologic sample data; preparation and analysis of potentiometric-surface maps, transmis- sivity maps, and water-quality maps; aquifer-test analysis; and low-flow streamflow analysis. A quasi-threedimensional, finite-difference ground-water flow model was also used to simulate steady-state predevelopment conditions and to simulate transient changes in the flow system caused by pumpage.

Included in the report are maps showing distribution of transmissivity for the different aquifers based on field data and model calibrations, predevelopment potentiometric surfaces, and 1982 potentiometric surfaces. Also included are maps that show the results of the analysis of recharge and discharge relations for the various aquifers based on streamflow data and ground-water flow simulation.

\section{DESCRIPTION OF THE STUDY AREA}

The study area covers about $35,000 \mathrm{mi}^{2}$ of which about $20,000 \mathrm{mi}^{2}$ compose the Coastal Plain of South Carolina (fig. 2). Also included in the study area are about 7,000 $\mathrm{mi}^{2}$ offshore, $5,000 \mathrm{mi}^{2}$ in eastern Georgia, and 3,000 $\mathrm{mi}^{2}$ in southeastern North Carolina.

The climate of the study area is temperate and characterized by hot, humid summers and moderate winters. The mean monthly temperatures at Columbia, S.C., range from $46^{\circ} \mathrm{F}$ to $81^{\circ} \mathrm{F}$. Precipitation in the Coastal Plain of South Carolina averages about 48 inches per year (in/yr) (South Carolina Water Resources Commission, 1983), is relatively uniformly distributed (fig. 3), and is seasonal in nature, with wet springs and summers and dry autumns. Stream discharge is greatest during the winter months and decreases during spring and summer, when plant growth rates are greatest.

\section{SOLTH CAROLINA PHYSIOGRAPHY}

The physiography of the South Carolina Coastal Plain varies from the upper to the lower parts. The western part of the upper Coastal Plain is characterized by "sand-hills" topography: long, gentle slopes and rounded summits cut by stream valleys filled with alluvium. Much of the eastern part of the upper Coastal Plain is a gently coastward-sloping surface that has been dissected by rivers and streams. Land-surface altitudes in the upper Coastal Plain range from more than 600 feet (ft) to less than $100 \mathrm{ft}$ above sea level, the highest altitudes occurring in interstream areas in the west, and the lowest altitudes in the valleys of large rivers.

The lower Coastal Plain is a low, broad plain. Numerous coastal terraces were formed during Pleistocene transgressions and regressions of the sea. The lower Coastal Plain slopes gently coastward, its altitudes ranging from more than $200 \mathrm{ft}$ above sea level to sea level. 


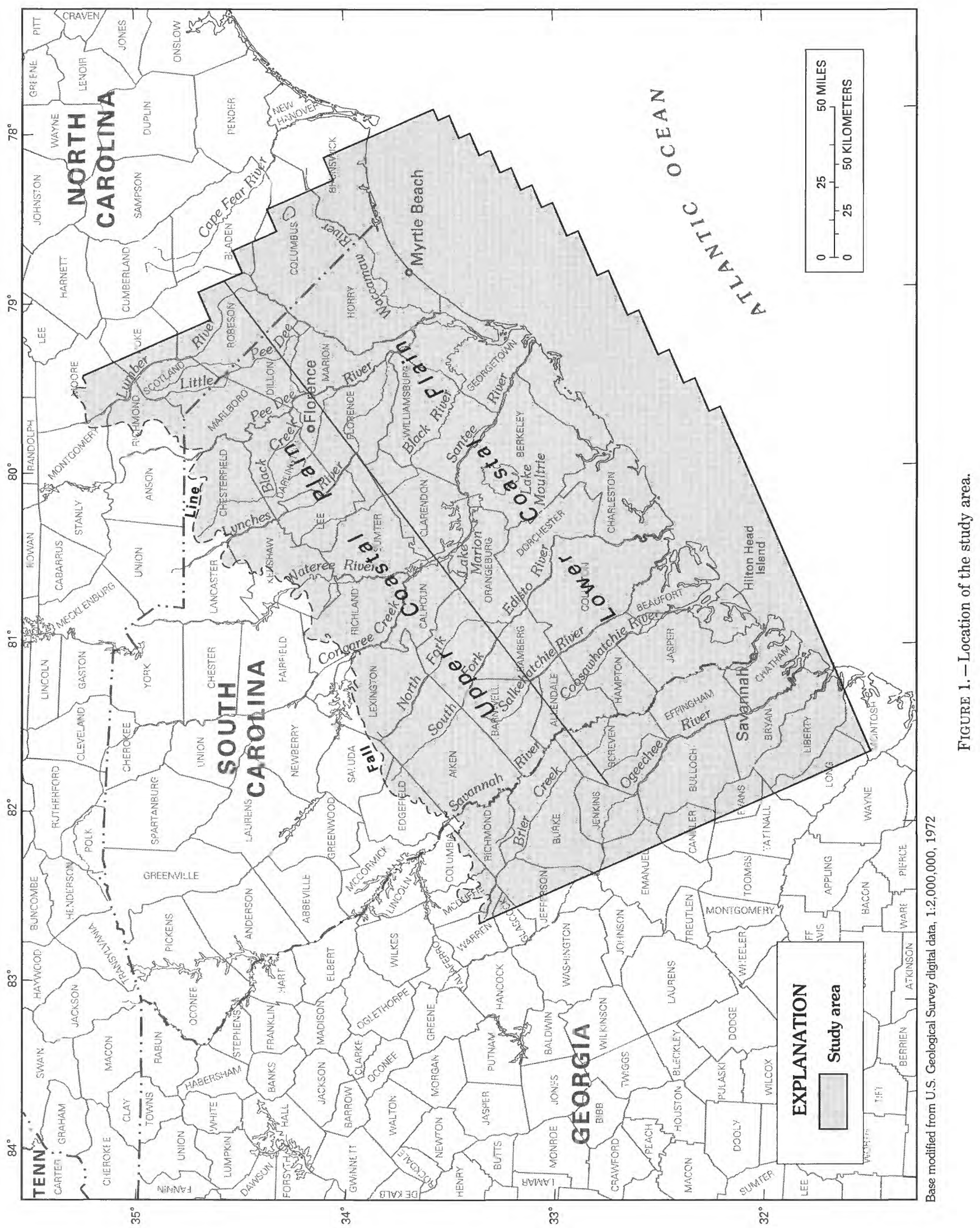




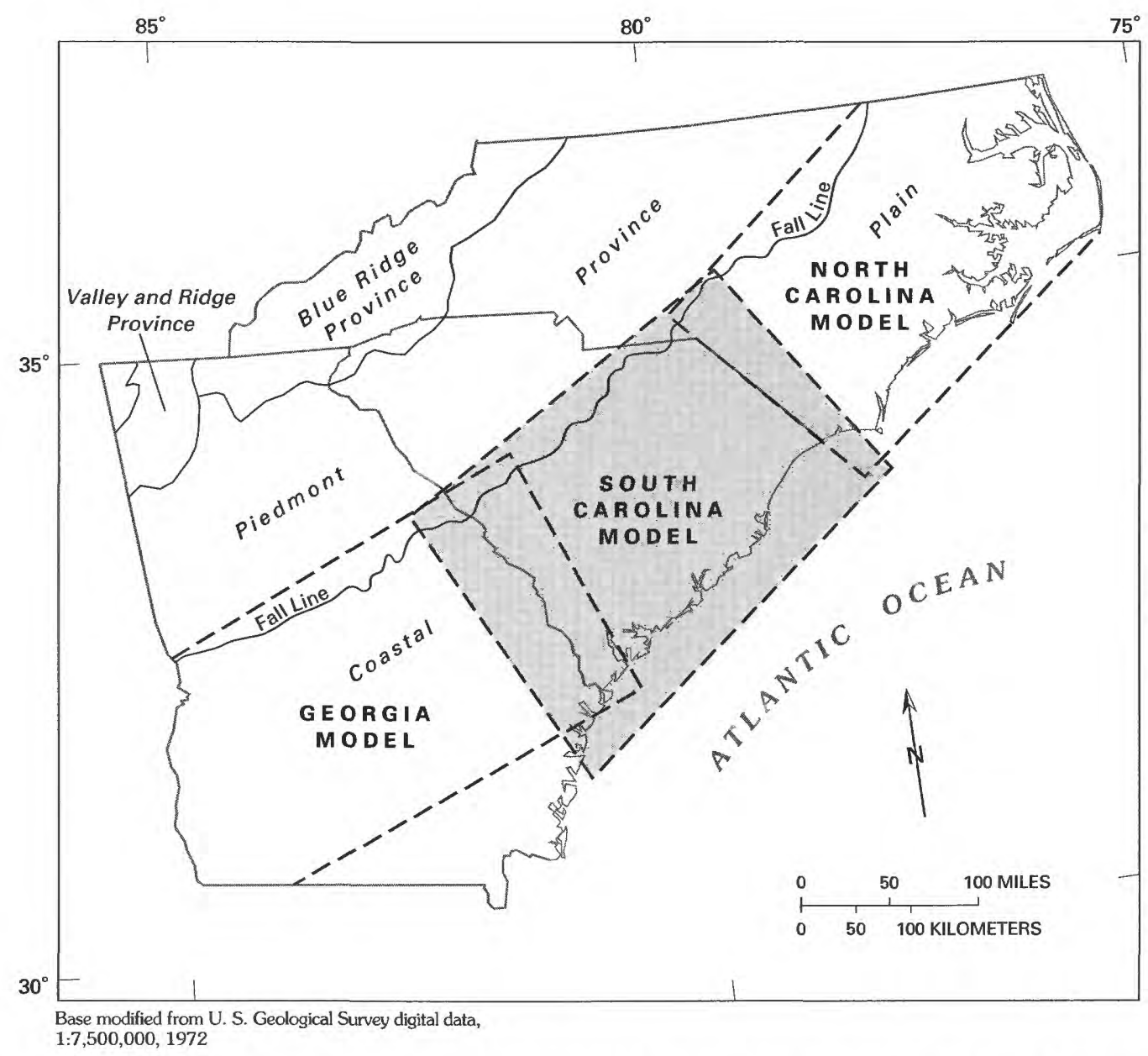

FIGURE 2. - The relation among overlapping models of the Coastal Plain aquifer systems in South Carolina, Georgia, and North Carolina (modified from Aucott, 1988).

The offshore part of the study area is part of the inner Continental Shelf. This shelf is a subsea extension of the broad lower Coastal Plain. Altitudes of the Continental Shelf range from sea level to $300 \mathrm{ft}$ below sea level within the study area.

\section{RIVERS}

The major rivers in the study area are the Savannah, Santee-Wateree-Congaree, and Pee Dee. The Cape Fear River in southeastern North Carolina lies just outside the study area to the north (fig. 1). Smaller rivers such as the North and South Forks of the Edisto River, the Lynches River, the Little Pee Dee River, the Lumber River, Brier Creek, and the Ogeechee River also are of regional importance. Many small rivers and streams also are present in the Coastal Plain, but they generally are not dealt with because of the scale of this regional study. The major rivers in the study area originate in the Appalachian Mountains or the Piedmont northwest of the study area and are all regulated. Most of the smaller rivers of regional importance originate near the inner margin of Coastal Plain sediments and are unregulated.

Average annual runoff in the South Carolina Coastal Plain is unevenly distributed (fig. 3). Runoff is greater in the sand-hills topography of the upper Coastal Plain than in the lower Coastal Plain. Discharge of streams varies less throughout the year in the upper Coastal Plain than in the lower Coastal Plain, as evidenced by a comparison of the average monthly discharge for the North Fork of the Edisto River at Orangeburg (upper Coastal Plain) with the Black River at Kingstree (lower Coastal Plain), shown in figure 3.

The major rivers are more deeply incised into the Coastal Plain sediments than smaller rivers. The Cape Fear and the Pee Dee Rivers are incised to the lowest altitude of all rivers at comparable distance from the Fall Line. Smaller rivers and streams tend to be much less deeply incised.

The characteristics of the beds of the Coastal Plain rivers have not been extensively studied. Because of low 


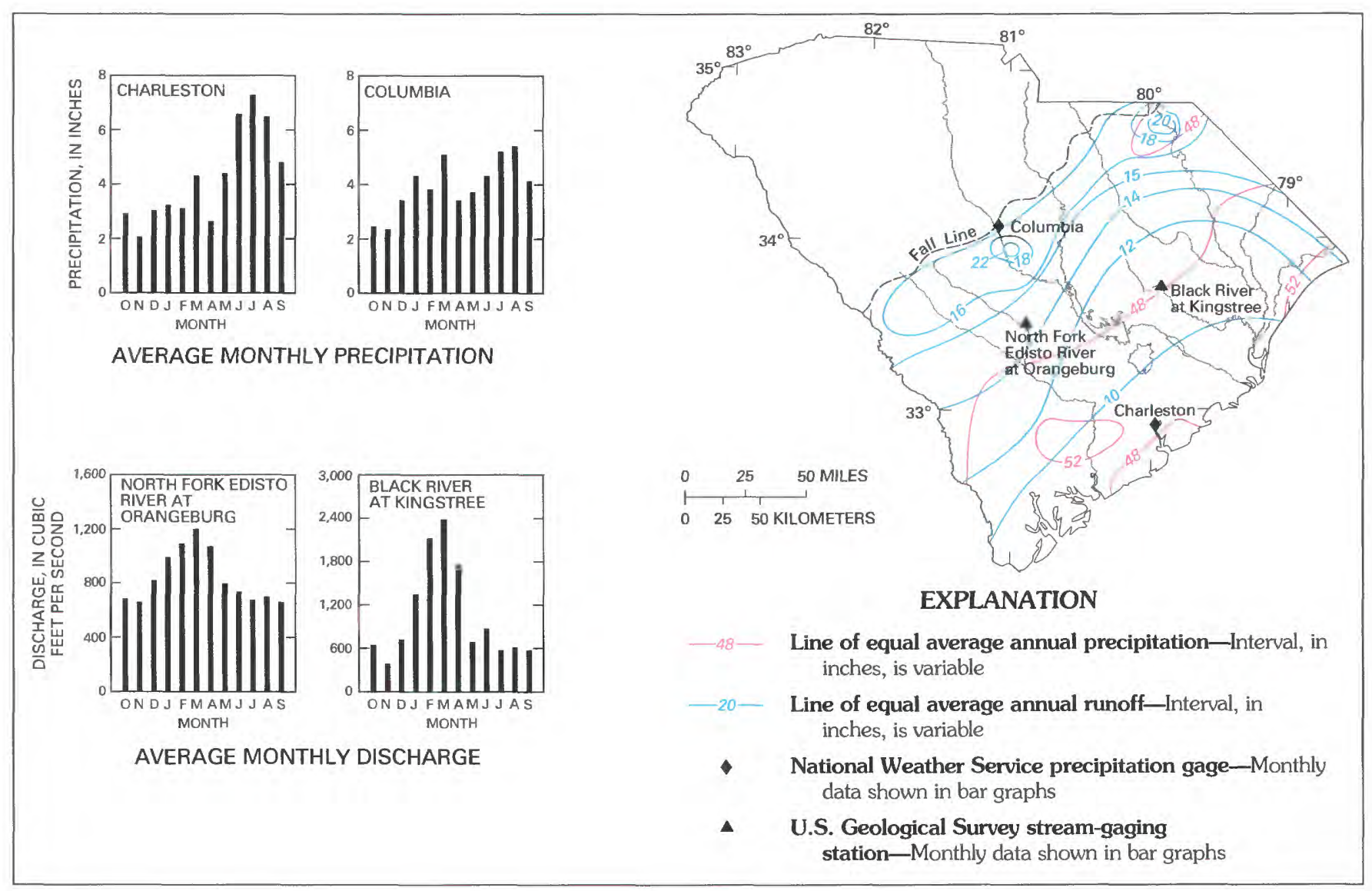

FIGURE 3.--Average annual precipitation and runoff in South Carolina and average monthly data for selected sites, $1951-80$ (modified from Sanders and Bohman, 1986).

gradients and low stream velocities, a relatively thick sequence of fine-grained sediment could have accumulated in streambeds, resulting in low values for the vertical hydraulic conductivities of streambeds in the major rivers in the study area in comparison with areas where gradients are higher or the sediment load is low. Some of the streams may have become incised to a level where clay beds in the geologic formations form the streambeds, also resulting in low hydraulic conductivity values in the streambed.

\section{PREVIOUS INVESTIGATIONS}

Previous investigations of the Coastal Plain groundwater flow system have been either of a local nature (Warren, 1944; Siple, 1967; Zack, 1977; Hayes, 1979; Park, 1980, 1985; Faye and Prowell, 1982; Pelletier, 1985) or rather general (Siple, 1957; LeGrand, 1964; Cederstrom and others, 1979). Ground-water flow models by Counts and Krause (1976), Bush (1982), Bush and Johnston (1988), Krause (1982), Randolph and Krause (1984), and Krause and Randolph (1989) have described the regional aspects of flow in the carbonate rocks of the Floridan aquifer system, parts of which are present in southwestern South Carolina and southeastern Georgia.

The availability of detailed information on the geohydrologic framework (Colquhoun and others, 1983; Renken, 1984, and in press; Aucott, Davis, and Speiran, 1987), comprehensive statewide potentiometric-surface maps (Aucott and Speiran, 1985b,c), a statewide evaluation of aquifer parameters (Aucott and Neweome, 1986), and results of preliminary ground-water flow modeling (Aucott, 1988) now enable more detailed and comprehensive regional descriptions of the hydrologic system to be made.

\section{GENERAL GEOHYDROLOGY}

The Coastal Plain Province is underlain by a wedge of unconsolidated to poorly consolidated sand, clay, silt, and limestone of Late Cretaceous and younger ages deposited on pre-Cretaceous metamorphic, igneous, and sedimentary rocks. These pre-Cretaceous rocks consist of sedimentary rocks of Triassic age and metamorphic and 
igneous rocks similar to those found at or near the land surface in the Piedmont (Overstreet and Bell, 1965; Marine and Siple, 1974; Gohn and others, 1977; Daniels and Zietz, 1978). The pre-Cretaceous rocks in South Carolina are much less permeable than the overlying sediments composing the aquifers of the Coastal Plain and are separated from them by a weathered mantle of low-permeability saprolite (Wait and Davis, 1986). The boundary between the Coastal Plain and the underlying pre-Cretaceous rocks is, therefore, an important boundary with respect to the flow of ground water in the Coastal Plain aquifers. The Coastal Plain sediments thicken eastward from the Fall Line that marks the inner margin of these sediments toward the present-day shoreline at an average rate of about 25 feet per mile (ft/mi). The Coastal Plain rocks can be divided into a series of aquifers and confining units based on the relative permeability, areal extent, and lithologic continuity of the sediments.

The subdivision of Coastal Plain sediments into geohydrologic units may either have a close correspondence to geologic formations or be relatively independent (Weiss and Williamson, 1985). In the study area the geohydrology is such that some correspondence exists between geologic and geohydrologic units. However, in places, geologic and hydrologic unit boundaries cross. The terminology used in this report for geohydrologic units is generally borrowed from the most important geologic unit included. The object of naming aquifers and confining units in this manner is to combine aquifer terminology and a comparatively well known geologic name, thereby providing an understanding of the relative position of each geohydrologic unit in the stratigraphic column. This terminology does not imply total congruence of stratigraphic and geohydrologic units, but rather a general correspondence.

The aquifers delineated herein consist of layers of sand or high-permeability limestone and are separated by confining layers of clay, silt, or low-permeability limestone. Water moves predominantly in a lateral direction within each of the aquifers. The confining units inhibit, but do not prevent, the vertical movement of water between aquifers. Vertical movement of water between aquifers is important on a regional scale, although locally it may be negligible in comparison to lateral flow within aquifers.

Regional geohydrologic frameworks have been developed for the carbonate rocks of the Floridan aquifer system (Miller, 1986) and for the predominantly clastic rocks of the Southeastern Coastal Plain aquifer system (Renken, 1984; Miller and Renken, 1988). These regional frameworks have been modified in South Carolina by subdividing and grouping some of the regional aquifers into a slightly different, somewhat more detailed frame- work that better represents the hydrology of the aquifers in the study area and takes into account differences in data density and scale (Aucott, Davis, and Speiran, 1987). More detailed discussions of the geohydrology of the Coastal Plain aquifers can be found in the reports mentioned above.

\section{GEOLOGIC STRUCTURE}

The structure of the study area is dominated by two features in the underlying rock: the Cape Fear arch and the Southeast Georgia embayment (fig. 4). The Cape Fear arch is a gentle upwarp with a southeastward axial plunge that increases near the coast and gradually decreases updip toward the Fall Line. The Southeast Georgia embayment is a shallow downwarp. As a result of these two features, the wedge of Coastal Plain sediments at the coast is much thicker to the southwest near Savannah, Ga. (greater than 4,000 ft), than it is to the northeast near the South Carolina-North Carolina border (about 1,300 ft). The Cape Fear arch is also responsible for the thinning or absence of Tertiary sediments in eastern South Carolina and near the South CarolinaNorth Carolina border.

Much investigation has been focused on faulting in the study area (Prowell and O'Connor, 1978; Faye and Prowell, 1982; Colquhoun and others, 1983; Miller, 1986). Some local faulting, which might be expected to have local hydrologic effects, has been well documented (Prowell and O'Connor, 1978). The existence of largescale faulting, and resulting hydrologic effects on the region, has not been established within the area.

\section{GEOHYDROLOGIC UNITS}

Six aquifers and intervening confining units compose the Coastal Plain aquifer system in the study area. In descending order, the aquifers are the surficial aquifer, the Floridan aquifer system, the Tertiary sand aquifer, the Black Creek aquifer, the Middendorf aquifer, and the Cape Fear aquifer. These aquifers generally consist of a single geologic formation or a group of formations, as listed in table 1 . This association is general because the lithology and hydrologic characteristics of a formation vary in a regional scale and because an aquifer may contain parts of more than one formation. The relation between the geohydrologic units defined in this study for South Carolina and those defined by Miller and Renken (1988) for the entire Southeastern Coastal Plain is also listed in table 1 and depicted in figure 5. Generalized geohydrologic sections in the study area (figs. 6 through 12) show the relations among the aquifers and the confining units that separate them. A generalized depiction of the areal extent of the Coastal Plain aquifers is 


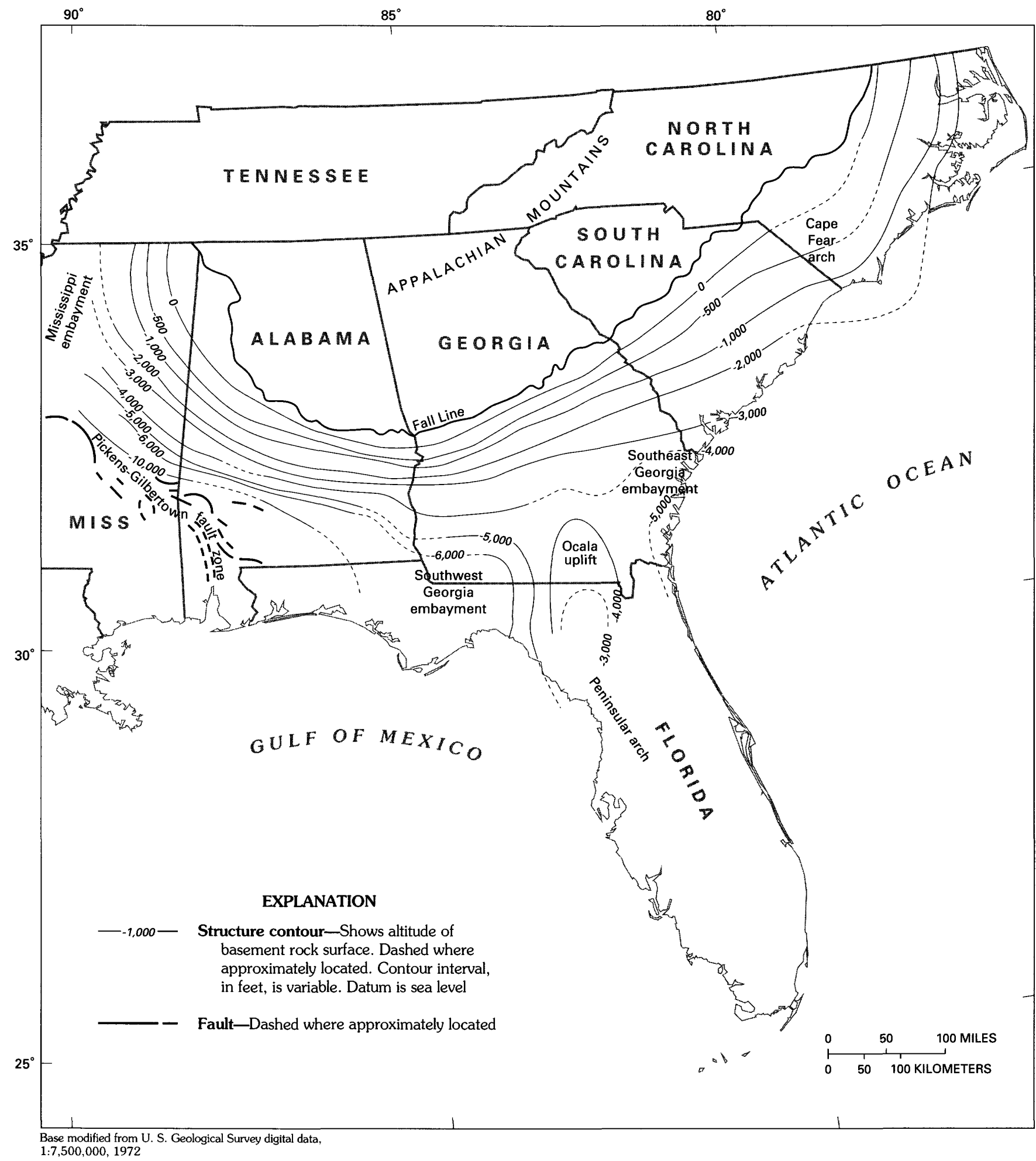

Figure 4.-Major structural features and altitude of pre-Cretaceous rocks in the Southeastern Coastal Plain (modified from Cederstrom and others, 1979). 
TABLE 1.-Generalized geohydrologic correlation chart [Modified from Siple, 1959; Do. and do., ditto]

\begin{tabular}{|c|c|c|c|}
\hline $\begin{array}{l}\text { Geologic } \\
\text { unit }^{1}\end{array}$ & Lithology & $\begin{array}{l}\text { Regional aquifers } \\
\text { of the Southeastern } \\
\text { Coastal Plain }^{2}\end{array}$ & $\begin{array}{l}\text { Coastal Plain } \\
\text { aquifers of } \\
\text { South Carolina }\end{array}$ \\
\hline \multicolumn{4}{|c|}{ Quaternary } \\
\hline $\begin{array}{l}\text { Coastal terrace } \\
\text { deposits. }\end{array}$ & $\begin{array}{l}\text { Sand and clay, reddish-brown, orange, } \\
\text { and white. }\end{array}$ & Surficial & Surficial \\
\hline \multicolumn{4}{|c|}{ Tertiary } \\
\hline $\begin{array}{l}\text { Cooper Group } \\
\text { (lower part). }\end{array}$ & $\begin{array}{l}\text { Limestone and marl, gray to white, silty } \\
\text { to sandy, phosphatic. }\end{array}$ & $\begin{array}{l}\text { Floridan } \\
\text { aquifer } \\
\text { system. }\end{array}$ & $\begin{array}{l}\text { Floridan } \\
\text { aquifer } \\
\text { system }^{3} \\
\text { (downdip). }\end{array}$ \\
\hline $\begin{array}{l}\text { Ocala } \\
\text { Limestone. }\end{array}$ & $\begin{array}{l}\text { Limestone, white to cream, calcitized, } \\
\text { fossiliferous, glauconitic. }\end{array}$ & do. & Do. \\
\hline $\begin{array}{l}\text { Santee } \\
\text { Limestone. }\end{array}$ & $\begin{array}{l}\text { Limestone, white to creamy yellow, } \\
\text { fossiliferous, glauconitic; interbedded } \\
\text { in part with gray to yellow sandstone. }\end{array}$ & do. & Do. \\
\hline $\begin{array}{l}\text { Barnwell } \\
\text { Formation. }\end{array}$ & $\begin{array}{l}\text { Sand, red to brown, fine- to coarse-grained, } \\
\text { massive. }\end{array}$ & Pearl River & $\begin{array}{l}\text { Tertiary } \\
\text { sand } \\
\text { (updip). }\end{array}$ \\
\hline $\begin{array}{l}\text { McBean } \\
\text { Formation. }\end{array}$ & $\begin{array}{l}\text { Sand, green to yellow, fine-grained, } \\
\text { glauconitic; gray-green glauconitic marl. }\end{array}$ & do. & Do. \\
\hline $\begin{array}{l}\text { Congaree } \\
\text { Formation. }\end{array}$ & $\begin{array}{l}\text { Sand and sandstone, yellowish-brown to } \\
\text { green, fine- to coarse-grained, } \\
\text { quartzose, glauconitic; dark-green to } \\
\text { gray clay. }\end{array}$ & do. & Do. \\
\hline $\begin{array}{l}\text { Black Mingo } \\
\text { Formation } \\
\text { (upper part). }\end{array}$ & $\begin{array}{l}\text { Shale, gray, sandy; black sandy } \\
\text { limestone, may be carbonaceous and } \\
\text { fossiliferous in places. }\end{array}$ & do. & Do. \\
\hline \multicolumn{4}{|c|}{ Cretaceous } \\
\hline $\begin{array}{l}\text { Black Creek } \\
\text { Formation. }\end{array}$ & $\begin{array}{l}\text { Sand, gray to white, quartzose, calcareous, } \\
\text { micaceous, phosphatic, glauconitic; } \\
\text { dark-gray to black, thinly laminated } \\
\text { clay containing nodules of pyrite and } \\
\text { marcasite and fragments of lignite. }\end{array}$ & $\begin{array}{l}\text { Chattahoochee } \\
\text { River. }\end{array}$ & Black Creek \\
\hline $\begin{array}{l}\text { Middendorf } \\
\text { Formation. }\end{array}$ & $\begin{array}{l}\text { Sand, light-gray, fine- to coarse-grained, } \\
\text { micaceous, glauconitic, in part } \\
\text { calcareous; green, purple, and maroon } \\
\text { clay; greenish-gray micaceous silty } \\
\text { sandstone. }\end{array}$ & $\begin{array}{l}\text { Chattahoochee } \\
\text { River. }\end{array}$ & Middendorf \\
\hline $\begin{array}{l}\text { Cape Fear } \\
\text { Formation. }\end{array}$ & $\begin{array}{l}\text { Clay, reddish-brown, gray to green; yellow } \\
\text { to white fine- to coarse-grained sand } \\
\text { with traces of mica. }\end{array}$ & $\begin{array}{l}\text { Black Warrior } \\
\text { River. }\end{array}$ & Cape Fear \\
\hline
\end{tabular}




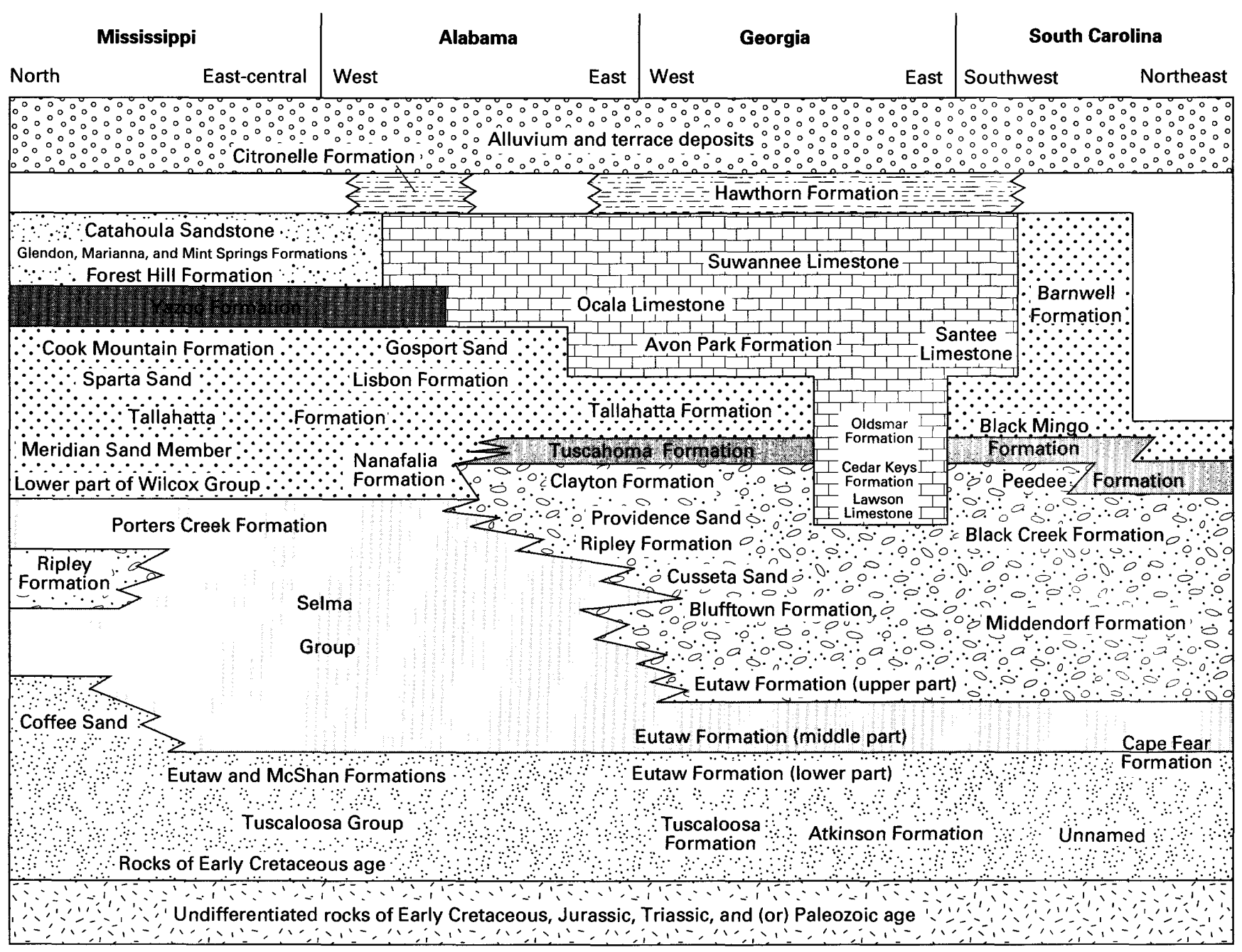

\section{EXPLANATION}

\begin{tabular}{|c|c|c|c|}
\hline $\begin{array}{lll}0 & 0 \\
0 & 0 & 0 \\
0 & 0 & 0\end{array}$ & Surficial aquifer & औा? & Chattahoochee River confining unit \\
\hline$=$ & Upper confining unit of Floridan aquifer system & 0.0 .98 & Chattahoochee River aquifer \\
\hline $\begin{array}{ll}71 \\
11 \\
1\end{array}$ & Floridan aquifer system & & Black Warrior River confining unit \\
\hline & Southeastern Coastal Plain aquifer system & & Black Warrior River aquifer \\
\hline & Chickasawhay River aquifer & 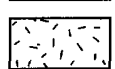 & Base of Southeastern Coastal Plain aquifer system \\
\hline & Pearl River confining unit & & Hydrogeologic unit absent \\
\hline
\end{tabular}

FIGURE 5.-Schematic diagram of regional geohydrologic units and selected rock-stratigraphic units in the Southeastern Coastal Plain (modified from Miller and Renken, 1988). 


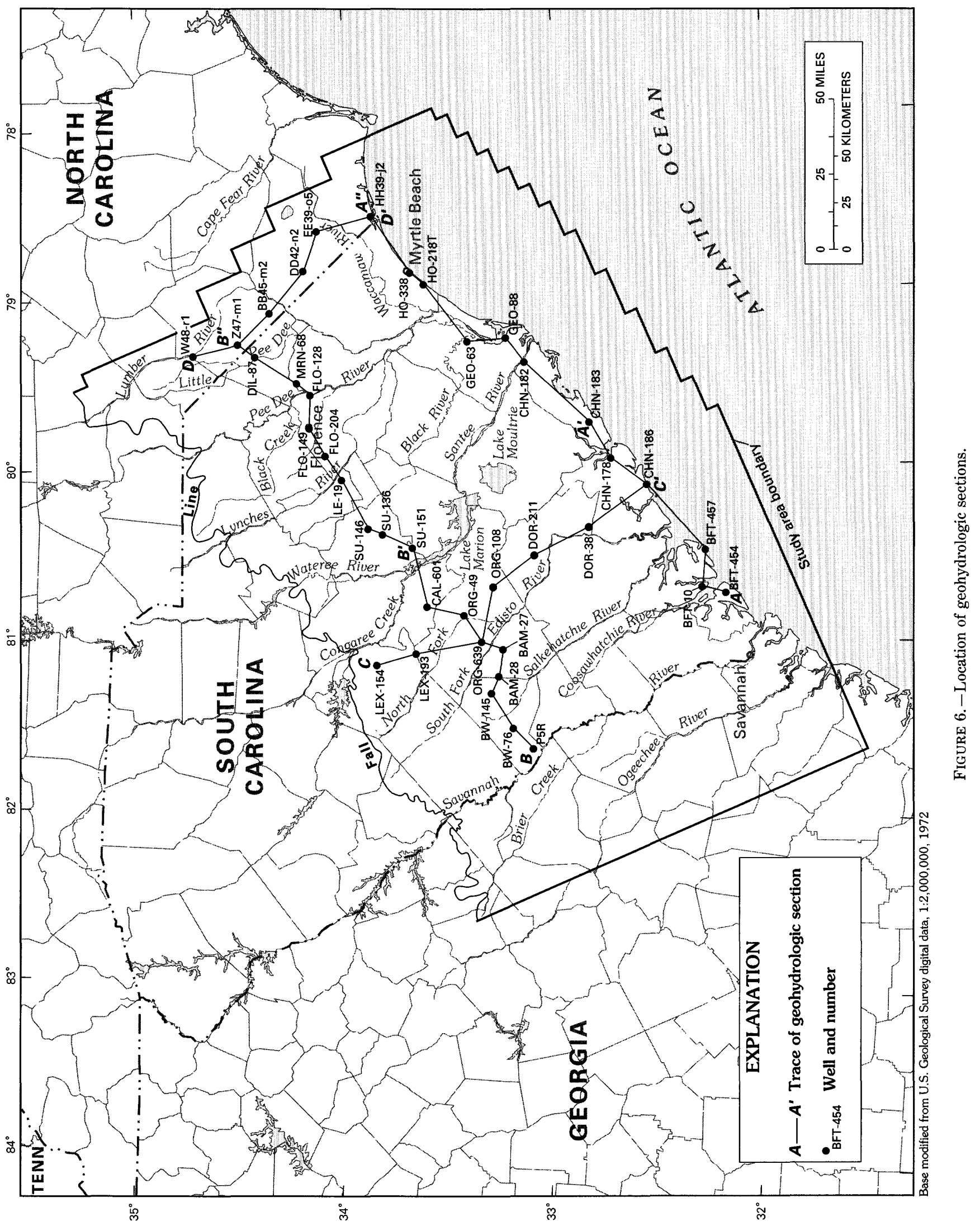




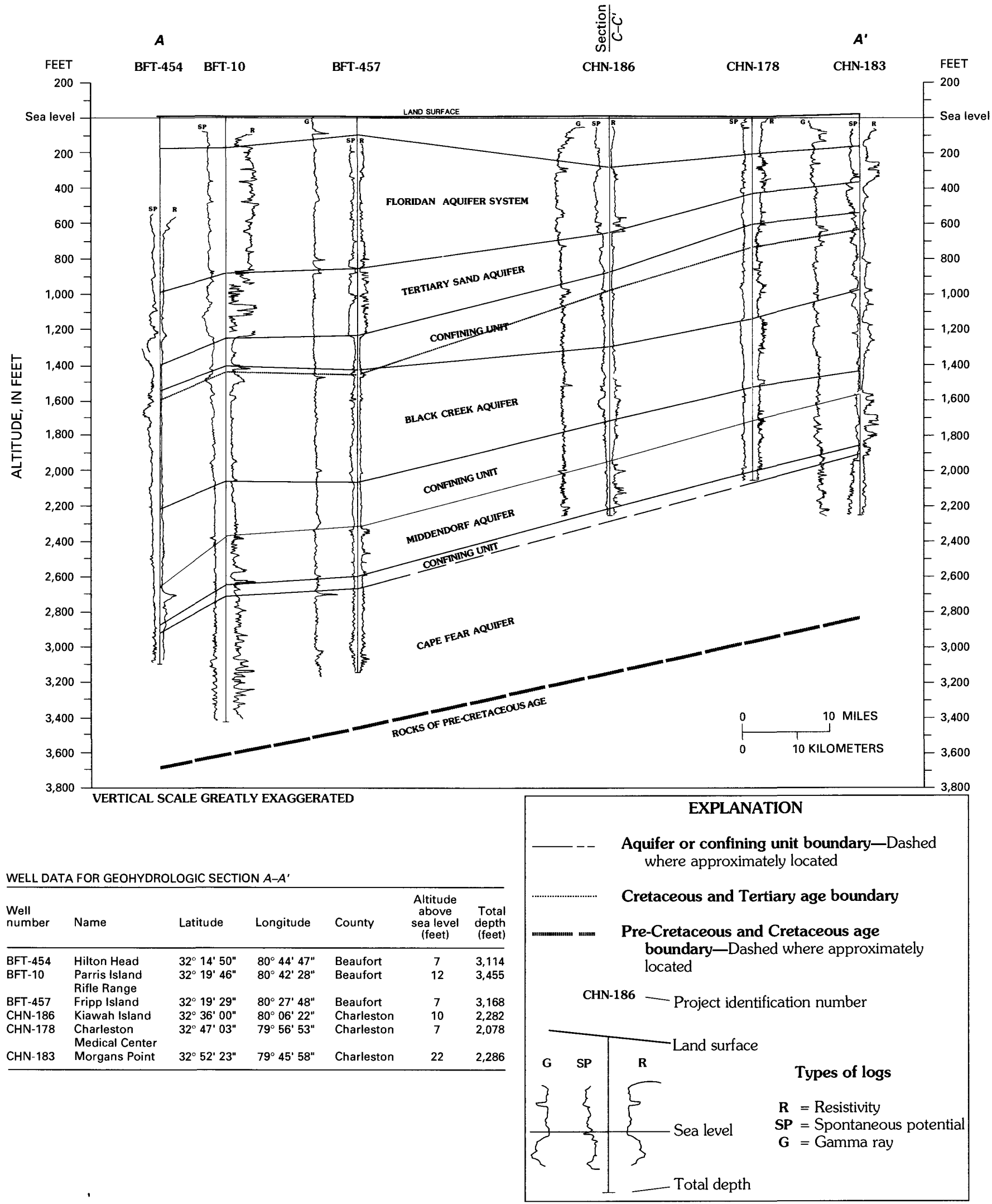

FigURE 7.-Generalized geohydrologic section $A-A^{\prime}$ (from Aucott, Davis, and Speiran, 1987). 


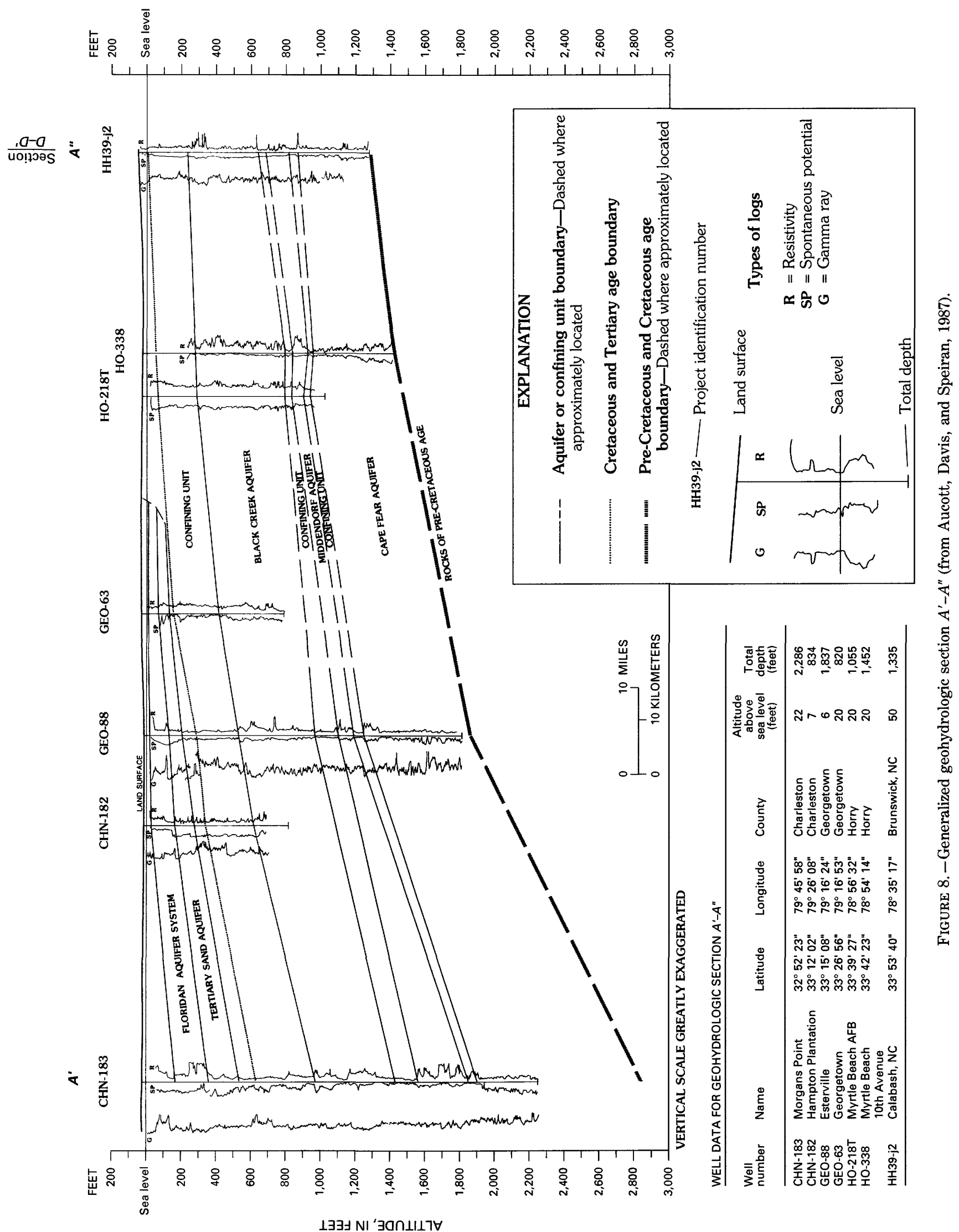



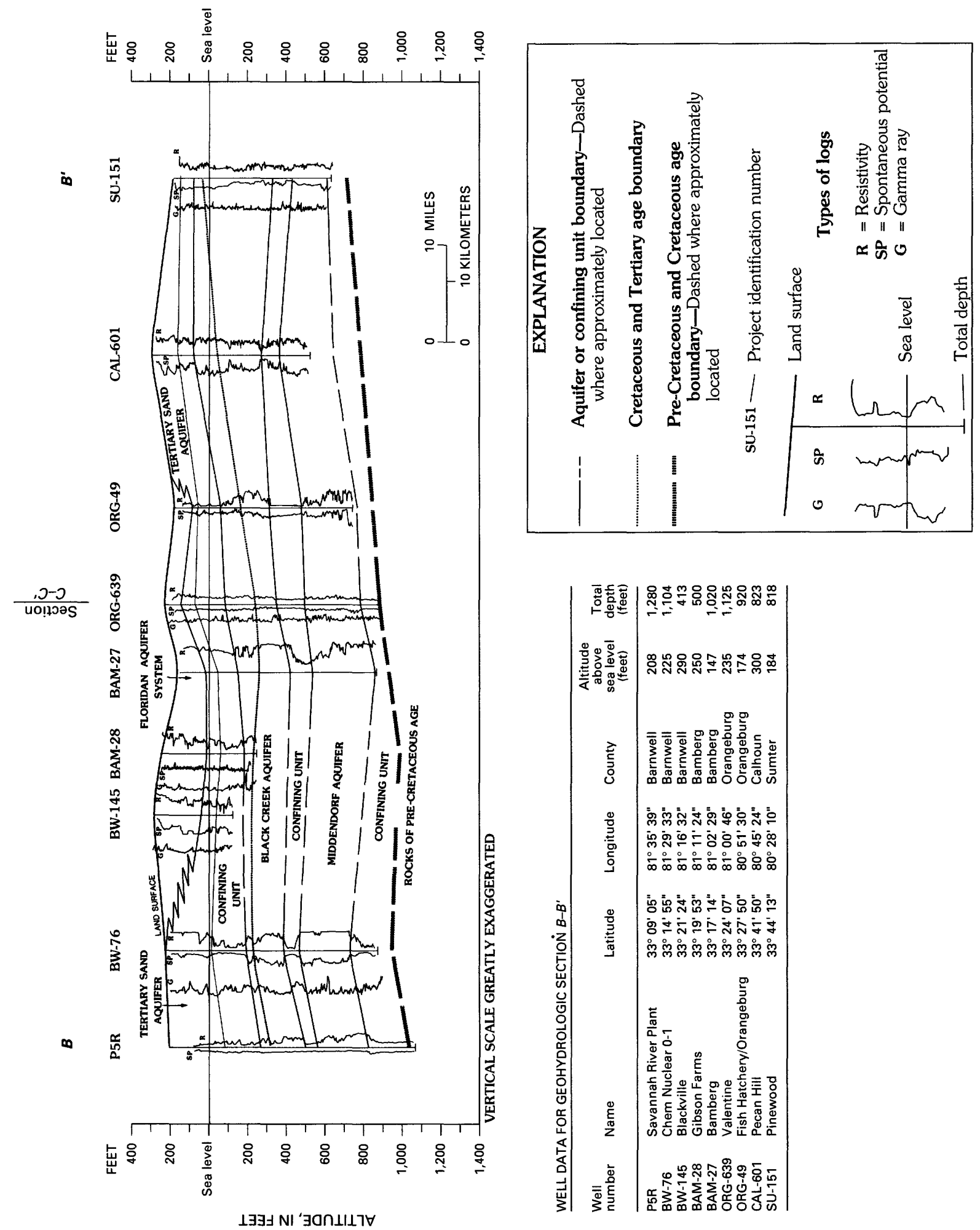

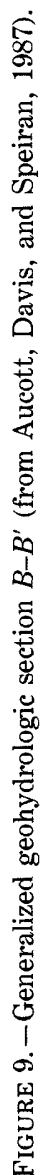

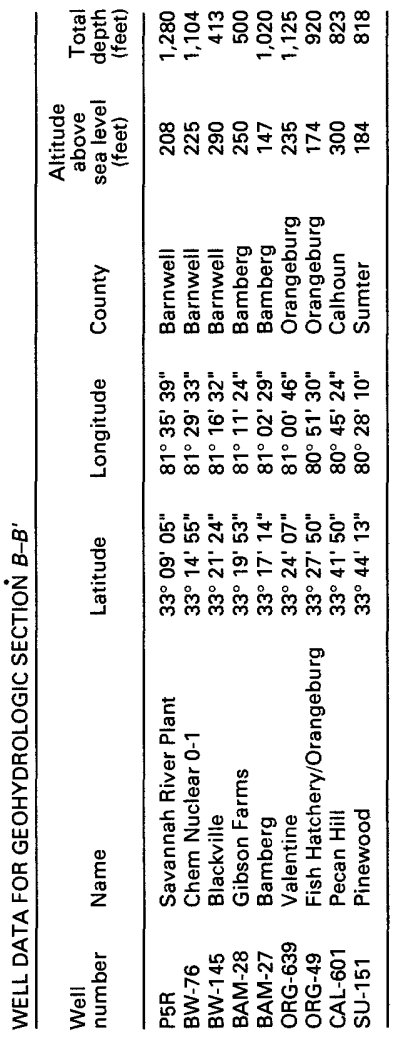




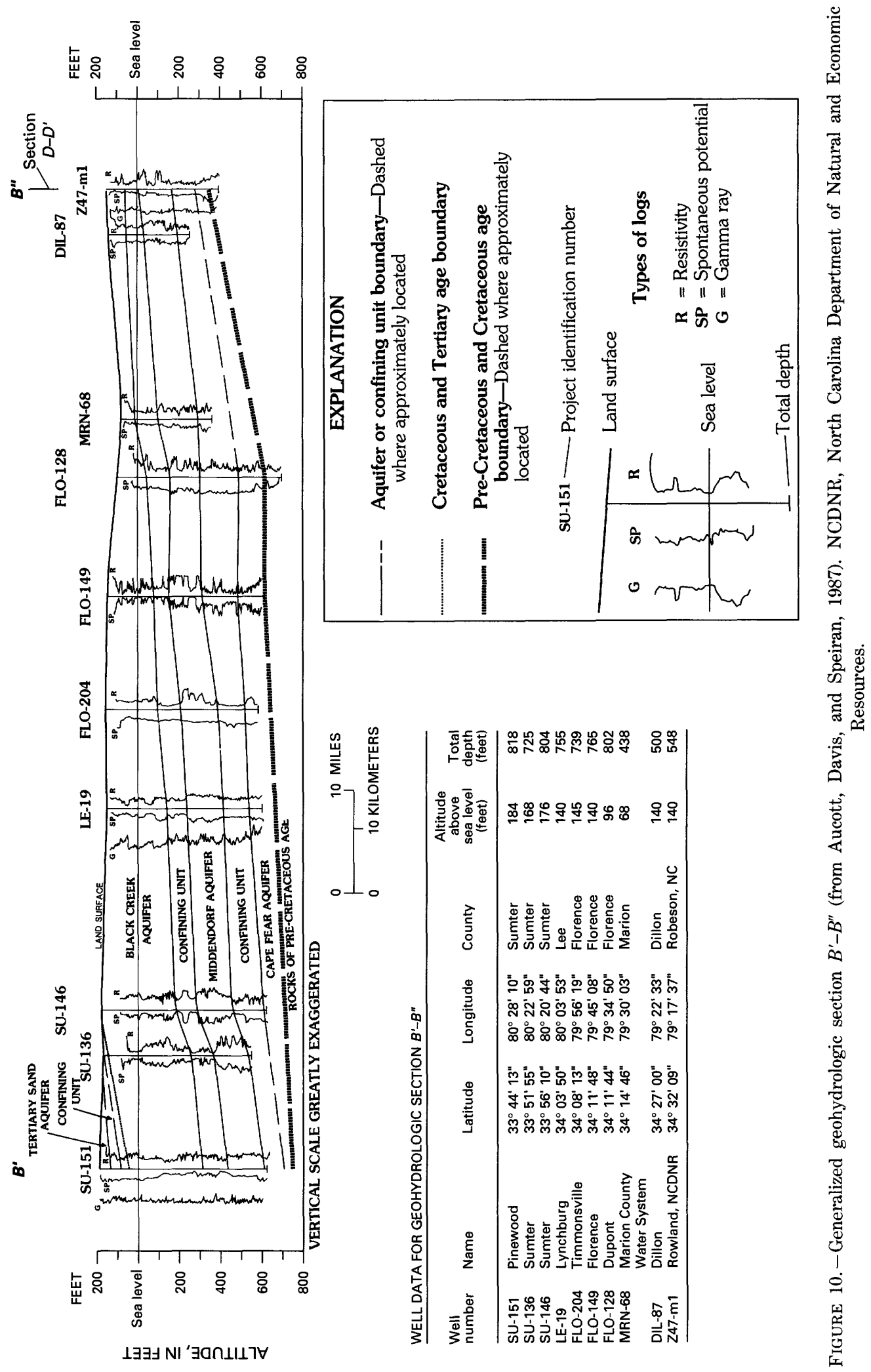




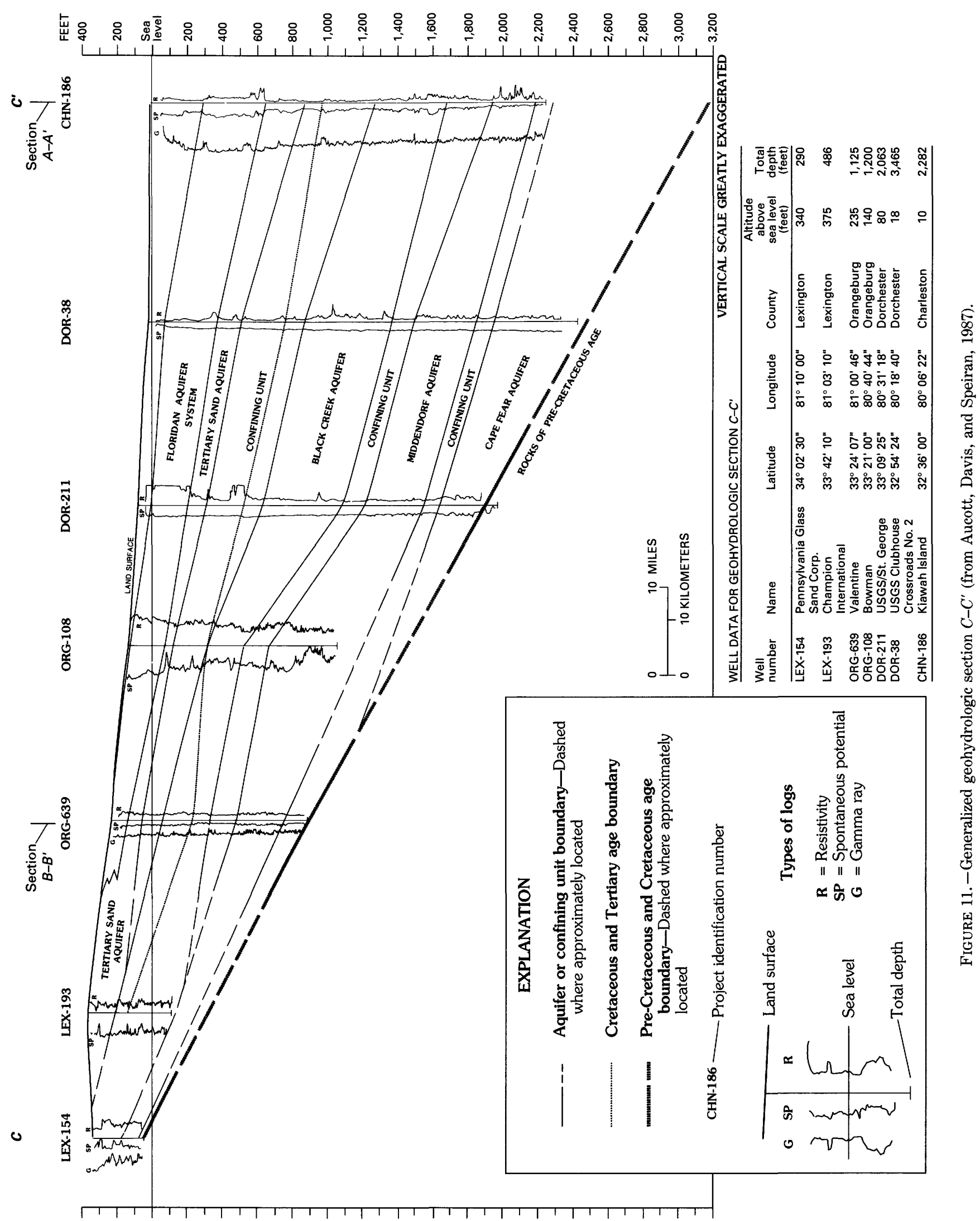

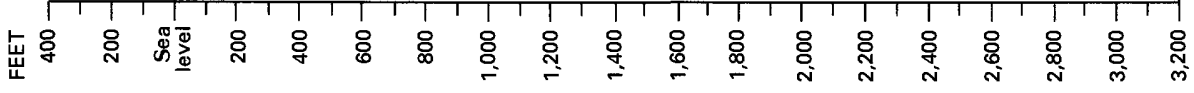




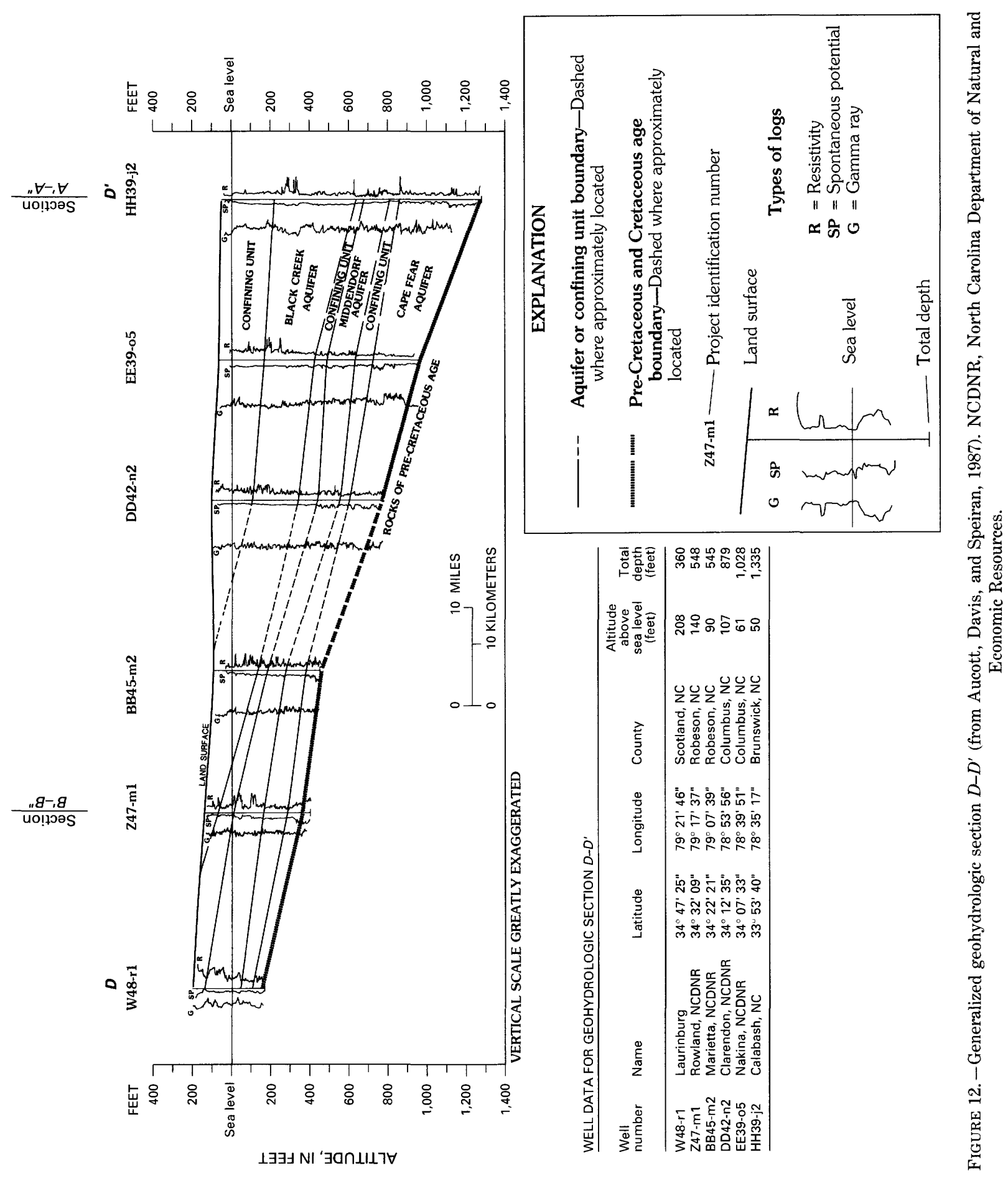


shown in figure 13. Additional geohydrologic sections, maps showing the altitude of the tops of aquifers, and description of the geohydrologic framework can be found in Aucott, Davis, and Speiran (1987).

\section{AQUIFERS AND AQUIFER SYSTEMS}

\section{Serficial Aquifer}

The surficial aquifer consists of marine terrace deposits. These sediments are generally less than $40 \mathrm{ft}$ thick and consist primarily of sand, shell, and clay that were deposited during a series of transgressions and regressions of the sea during the Pleistocene Epoch (Siple, 1946). The surficial aquifer is present throughout the lower Coastal Plain (fig. 13) and contains water under unconfined conditions. It overlies the Floridan aquifer system in the western part of the lower Coastal Plain and the Black Creek aquifer in the eastern part of the lower Coastal Plain.

\section{Floridan Aquifer System}

The term "Floridan aquifer system" was applied by Miller (1986) to rocks previously called the Tertiary limestone aquifer, the principal artesian aquifer in parts of South Carolina and Georgia, and the Floridan aquifer in Florida. The Floridan aquifer system in South Carolina generally consists of white to creamy-yellow limestone of late to middle Eocene age. The sediments composing this system are parts of the Cooper Group, the Ocala Limestone (where present), and the underlying Santee Limestone (table 1). The Floridan aquifer system, as defined regionally by Miller (1986), was expanded and redefined locally by Aucott, Davis, and Speiran (1987) in South Carolina to include the permeable parts of the Santee Limestone in outcrop and in the subsurface. The redefined Floridan aquifer system extends over the southwestern one-third of the Coastal Plain of South Carolina (fig. 13). It ranges in thickness from a featheredge, where it pinches out, to more than $700 \mathrm{ft}$ in Beaufort County (fig. 7).

The hydraulic characteristics of the Floridan aquifer system result from primary and secondary porosity. The upper part of the Ocala Limestone contains coquina and has a high primary porosity. Secondary porosity that results from the dissolution of calcium carbonate is locally present but is not as significant in the Floridan aquifer system in South Carolina as in the cavernous limestones in some parts of Florida and Georgia. The hydraulic conductivity of the Santee Limestone generally is lower than that of the Ocala because the clay content of the Santee is greater. The net result is that the transmissivity of the Floridan aquifer system is higher in the southern part of South Carolina, where the Ocala Limestone is present (Hayes, 1979).

\section{Tertiary SAND AQuifer}

The Tertiary sand aquifer partly underlies the carbonate rocks composing the Floridan aquifer system and partly is the clastic facies equivalent of the carbonate rocks. The Tertiary sand aquifer extends from near the Fall Line toward the coast in western South Carolina and southeastern Georgia (fig. 13). It varies in thickness up to a maximum of over $400 \mathrm{ft}$ in Barnwell County immediately updip of the Floridan aquifer system limit. The Tertiary sand aquifer previously has been informally designated as aquifer A2 (Renken, 1984; Aucott and Speiran, 1985b,c). Sediments composing this aquifer include the Barnwell, McBean, and Congaree Formations and the upper part of the Black Mingo Formation (table 1); they consist of fine to medium sand and clay, commonly light greenish yellow to orange. Local erosional remnants of the Santee Limestone that occur in updip areas and are isolated from the main body of limestone composing the Floridan aquifer system are also included in the Tertiary sand aquifer. Sediments from these Eocene and upper Paleocene formations are considered as a single aquifer in this report. Although locally there are vertical differences in hydraulic head within parts of this aquifer, particularly in parts of Georgia and South Carolina near the Savannah River, these head differences are not important enough regionally in this study area to subdivide this aquifer vertically, as has been done in the RASA study of the adjacent Georgia Coastal Plain.

Black Creek Aquifer

The Black Creek aquifer consists mostly of sediments of the Black Creek Formation and its equivalents but may locally include sediments that are part of the overlying Peedee Formation or the underlying Middendorf Formation (table 1). Sediments composing the Black Creek Formation are principally thin, laminated layers of gray, fine to medium, micaceous sand and dark-gray to black clay. The coarseness of the sands and the clay content vary areally. The Black Creek aquifer is the uppermost regional aquifer consisting of sediments of Cretaceous age. This aquifer has been informally called aquifer A3a2 in previous reports (Renken, 1984; Aucott and Speiran, 1985b,c). The updip limit of the Black Creek aquifer is in the upper Coastal Plain and generally parallels the Fall Line in the western part of the Coastal Plain (fig. 13). This aquifer occurs in outcrop in the eastern part and subcrop in the western part of its updip limit. It generally is between 300 and $600 \mathrm{ft}$ thick through much of its areal extent except near its updip pinchout. 


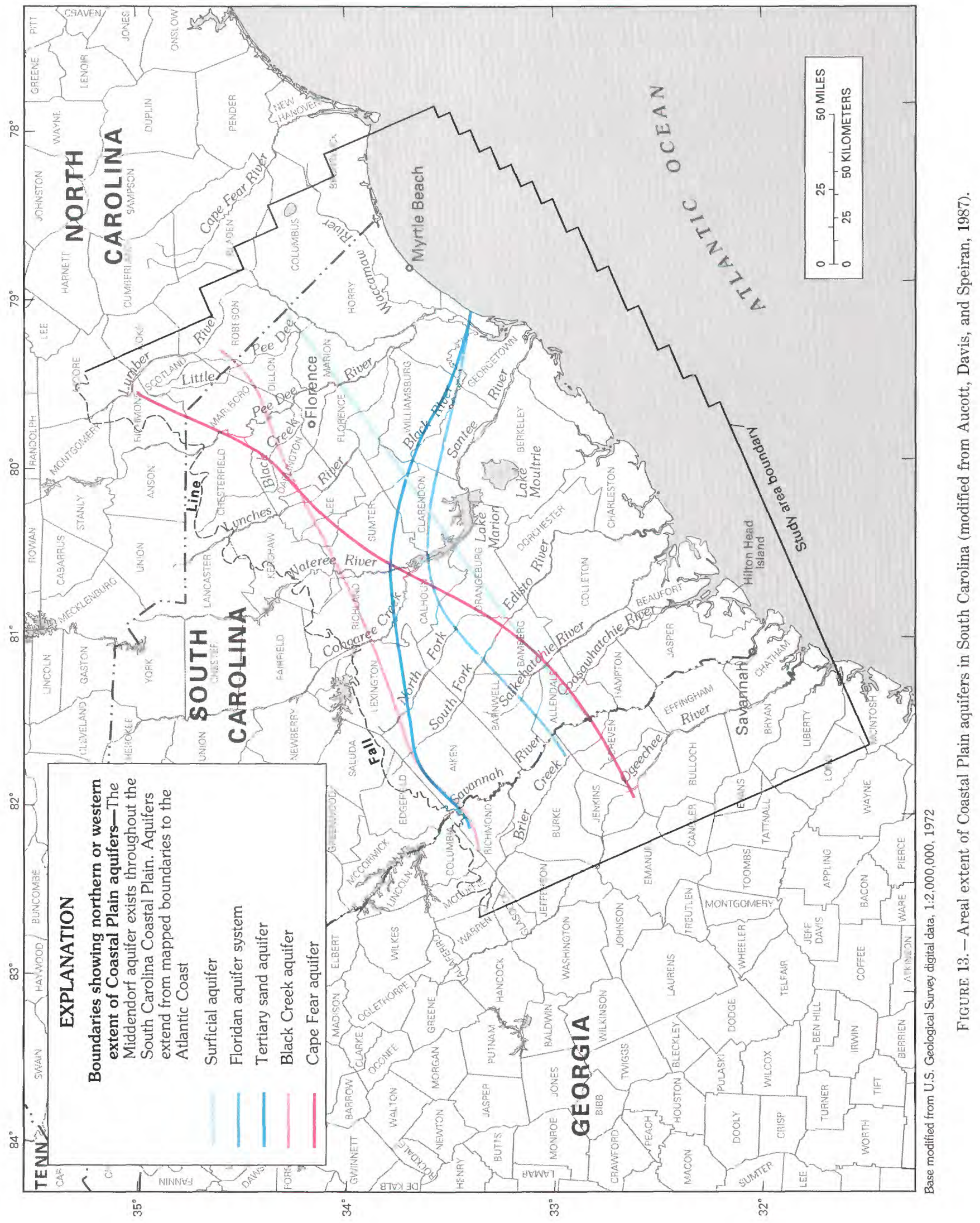


In the eastern part of the Coastal Plain, the hydraulic conductivity of the fine to medium sand of the Black Creek aquifer is relatively consistent (Aucott, 1988). As a result, the transmissivity of the aquifer increases as the aquifer thickens toward the coast, then remains fairly constant where the aquifer thickness is relatively constant. In the western part of the upper Coastal Plain, the transmissivity of the Black Creek aquifer is relatively high because of the coarse sand and low clay content of the aquifer. In the southern part of the study area, the higher clay content of the sediments causes the transmissivity of the aquifer to be much lower than in the upper Coastal Plain or along the coast to the east (Aucott and Newcome, 1986; Aucott, Davis, and Speiran, 1987).

\section{MidDENDORF AQUifer}

The Middendorf aquifer consists mostly of sediments of the Middendorf Formation but locally may include sediments of the overlying Black Creek Formation or the underlying Cape Fear Formation. This aquifer has previously been referred to as all or part of the "Tuscaloosa aquifer" (Siple, 1957; Park, 1980) and informally as aquifer A3a3 (Renken, 1984; Aucott and Speiran, $1985 b, c)$.

In outcrop areas and in the subsurface of the upper Coastal Plain, sediments of this aquifer primarily are light gray, white, and buff sand commonly interfingered with lenses of white, pink, or purple clay, all of which were deposited in an upper delta-plain environment. In the lower Coastal Plain, the sediments of the Middendorf aquifer are lithologically similar to those of the Black Creek aquifer and consist of thin, laminated layers of fine to medium sand and clay. The Middendorf aquifer occurs throughout the Coastal Plain of South Carolina and crops out along the Fall Line except locally in the western part of the Coastal Plain, where it is covered by younger rocks. Although the maximum thickness of the Middendorf aquifer is about $400 \mathrm{ft}$, it is more typically about 200 ft thick.

The transmissivity of the Middendorf aquifer varies in a pattern of bands that are approximately parallel to the Fall Line. The Middendorf sediments in the upper Coastal Plain are lithologically similar for some distance from the Fall Line. Because the aquifer thickens away from the Fall Line and toward the coast, the transmissivity generally increases coastward. Siple (1957) first noted that the transmissivity of the Middendorf aquifer, which he called the Tuscaloosa aquifer, is greatest in a band approximately parallel to the Fall Line in the lower part of the upper Coastal Plain. In this band, aquifer thickness remains constant, but transmissivity is greater on the west side of the band because there the aquifer contains coarser sand and little clay.
In the lower Coastal Plain, the hydraulic conductivity of the Middendorf aquifer generally decreases toward the coast as the percentage of clay in the aquifer increases. This increase in clay results in a general decrease in transmissivity despite a small increase in thickness in some areas. Despite this decrease, the transmissivity of the Middendorf aquifer near the coast is as great as or greater than that of adjacent aquifers. Conclusions about transmissivity are based on lithologic data, aquifer-test data (Aucott and Newcome, 1986), and the fresher quality of the water (Speiran and Aucott, 1991), which indicates more complete flushing and thus a more active flow system in the Middendorf aquifer than in overlying or underlying aquifers.

$$
\text { Cape Fear Aquifer }
$$

The Cape Fear aquifer consists of the lower part of the Cape Fear Formation and is the basal aquifer in the Coastal Plain aquifer system of South Carolina. It has informally been referred to previously as aquifer A4 (Renken, 1984; Aucott and Speiran, 1985b,c), as the lower part of the Middendorf aquifer (Colquhoun and others, 1983), or as the Middendorf aquifer (Zack, 1977). The Cape Fear aquifer consists predominantly of sand, silt, and gravel separated by relatively thick silt and clay layers. The Cape Fear aquifer occurs entirely in the subsurface, and the extent of this aquifer has not been well defined in the Coastal Plain of South Carolina. The aquifer probably occurs only in the lower Coastal Plain and the eastern part of the upper Coastal Plain. Because shallower aquifers, particularly the overlying Middendorf aquifer, contain water that is less mineralized and yield more water to wells, few wells penetrate the Cape Fear aquifer, and as a result, it is poorly defined.

\section{CONFINING UNITS}

Much less is known about the hydraulic and lithologic characteristics of the confining units than is known about the aquifers of the Coastal Plain aquifer system. Previous investigations concentrated on water-supply considerations, resulting in much more information on aquifers than on confining units. Vertical movement of water within the aquifer system is controlled by the confining units, which are the geohydrologic units of lowest permeability. Vertical movement across a confining unit is usually controlled by the least permeable layer within the confining unit, which is typically a tight, marine clay in the Coastal Plain sediments of South Carolina. All of the confining units identified allow limited vertical movement of water through them.

The confining unit between the surficial aquifer and underlying aquifers is not composed of a single formation. Accordingly, its hydraulic characteristics probably 
vary substantially. Where the surficial aquifer is underlain by the upper part of the Cooper Group in the central and eastern parts of the lower Coastal Plain (Colquhoun and others, 1983), this confining unit generally is extremely effective in inhibiting the vertical movement of water. Moreover, many discrete layers of clayey material occur in the surficial aquifer, even within the coastal terrace deposits, locally creating artesian conditions at shallow depths below the water table.

The confining unit that seems to have the greatest effect on the ground-water flow system in the Coastal Plain consists of the lower part of the Black Mingo Formation and other clayey Paleocene sediments. This confining unit is located below the Floridan aquifer system and the Tertiary sand aquifer, but above the Black Creek and Middendorf aquifers.

The effectiveness of a confining unit in inhibiting vertical flow can cause considerable differences in the flow systems of the aquifers immediately above and below it. Such differences are most commonly reflected as head and water-quality differences between the aquifers. The effectiveness of the clayey Paleocene sediments in inhibiting the vertical movement of water in the southern part of the Coastal Plain is illustrated by the contrasting flow systems in the overlying and underlying aquifers (Aucott and Speiran, 1985a). Where this confining unit thins and contains more sand northwestward toward its updip limit and northeastward toward the Cape Fear arch, it becomes less effective in inhibiting vertical movement of water.

The confining unit between the Black Creek aquifer and the Middendorf aquifer primarily consists of sandy clay in the lower part of the Black Creek Formation. Because it is sandy, this unit is probably not as effective as other confining units in the system in inhibiting vertical flow. Under nonpumping conditions, the flow systems of the Black Creek and Middendorf aquifers appear to be quite similar (Aucott and Speiran, 1985b). However, under pumping conditions, major head differences exist between the two aquifers. Water-quality differences between these aquifers also occur in some areas. Accordingly, this confining unit is more effective than its sandy lithology would indicate.

The confining unit between the Middendorf and Cape Fear aquifers is very effective in separating the flow systems of these aquifers in the eastern part of the study area. This separation is recognized by differences in water quality and head between these aquifers (Aucott and Speiran, 1985b, 1986). In the western part of the lower Coastal Plain and eastern part of the upper Coastal Plain, the effectiveness of this confining unit is not well defined. Limited data indicate that water-quality differences exist but head differences appear to be minor.

\section{GROUND-WATER FLOW SYSTEM}

Water enters the Coastal Plain aquifers primarily as recharge from precipitation in topographically high parts of aquifer outcrop areas. The water percolates downward to the water table, and most of it then moves laterally along short flow paths to discharge as base flow to small streams. Some of the water enters deep, confined parts of the aquifers and follows longer flow paths down the hydraulic gradient. In downdip areas, this deeply circulating water moves upward and discharges to shallower aquifers, and eventually to the ocean. Most of the discharge in downdip areas is by leakage through confining units that separate the aquifers.

\section{STRATIFICATION OF FLOW SYSTEM}

The ground-water flow system in the upper Coastal Plain of South Carolina is considered to be a stratified system similar to the system described by Winter (1976) and shown in figure 14. Water enters the system as recharge in topographically high areas between rivers and lakes, flows down the hydraulic gradient, and discharges to rivers, lakes, and swamps. Such factors as topography, aquifer thickness, and aquifer transmissivity affect a stratified flow system, as described by Toth (1963), Freeze and Witherspoon (1966), and Winter (1976) and as depicted in figure 14. Such a flow system consists of a continuum of shallow, intermediate, and deep flow systems. Water moving in the shallow flow system has a different flow path, velocity, and area of discharge than water in the deep system.

The shallow flow system is characterized by relatively short flow paths. Typically, much of the water in a stratified ground-water system moves through the shallow flow system at relatively high velocities and discharges to surface-water bodies located near the recharge areas. The shallow flow system is close to land surface and may be relatively thin. As a result, variations in recharge over time could have a considerable effect on the amount of water flowing in the shallow flow system.

In contrast to the shallow system, the deep flow system is characterized by much longer flow paths and much lower velocities. Because the time of travel from sources of recharge to areas of discharge is longer for the deep flow system than for the shallow flow system, the deep flow system is less affected by short-term hydrologic factors such as seasonal variations in recharge. The deep flow system as it pertains to the Coastal Plain aquifers is defined as that part of the flow system that either discharges to rivers that act as regional drains or flows downgradient to deeply buried parts of the aquifers in the lower Coastal Plain. The regional drains in the 


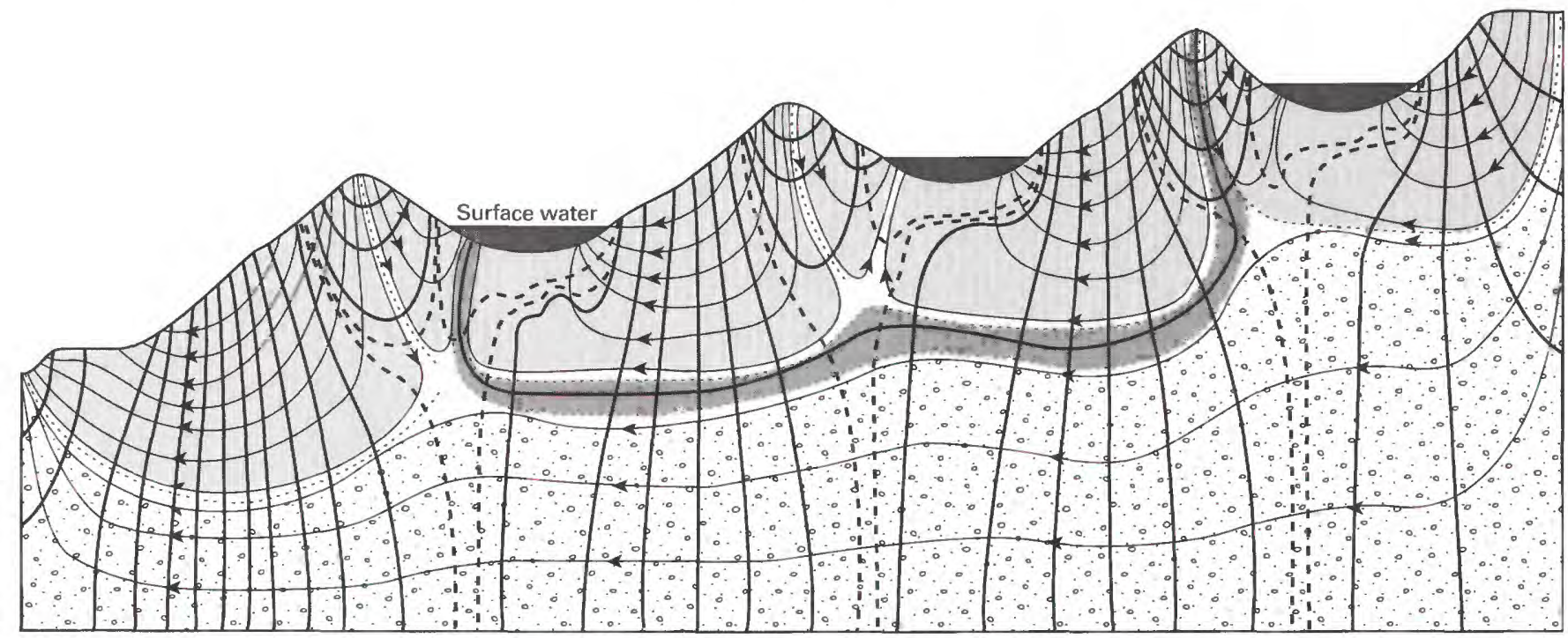

EXPLANATION

Zone of shallow ground-water flow system

Zone of intermediate ground-water flow system

$\because \therefore$ Zone of deep ground-water flow system

- - Line of equal hydraulic potential-Dashed

lines are supplemental contours

$\longleftarrow$ Flow line

Boundary of flow system

Figure 14.-Diagrammatic section of a stratified ground-water flow system (from Winter, 1976).

study area are the Savannah, North Fork Edisto, South Fork Edisto, Congaree, Wateree, Lynches, Pee Dee, and Lumber Rivers. The regional drains are more deeply incised into the Coastal Plain sediments than are smaller rivers. Computation of discharge to regional drains in the upper Coastal Plain of South Carolina is discussed by Aucott, Meadows, and Patterson (1987).

Intermediate flow systems probably also occur in the upper Coastal Plain between the shallow and deep flow systems (fig. 14), but they are more difficult to define or quantify. Intermediate flow systems have characteristics between those of the shallow and deep systems.

Many factors that affect ground-water discharge to streams also determine the extent to which the groundwater flow system will be stratified. Some of these factors include variations in topography; aquifer characteristics such as hydraulic conductivity, storage coefficient, and thickness; the quantity and spatial and temporal distribution of recharge; and conditions affecting discharge, such as stream altitude and incisement and streambed hydraulic conductivity.

\section{PREDEVELOPMENT FLOW SYSTEM}

The regional or deep ground-water flow system of the Coastal Plain aquifers in the study area can be best described areally with the aid of potentiometric-surface maps of the aquifers. Figures 15 through 18 are potentiometric-surface maps based on measured water levels or artesian heads and show flow lines for the Floridan aquifer system and the Tertiary sand aquifer, the Black Creek aquifer, the Middendorf aquifer, and the Cape Fear aquifer, respectively. A water-table map of the surficial aquifer is not presented because of the localized nature of its flow system. The potentiometric maps were developed by Aucott and Speiran (1985b,c) for South Carolina and extended into Georgia using data from R.E. Faye (U.S. Geological Survey, written commun., 1984) and into North Carolina using data from the U.S. Geological Survey and the North Carolina Department of Natural and Economic Resources. The maps depict the predevelopment potentiometric surfaces, which are defined as the long-term average potentiomet- 


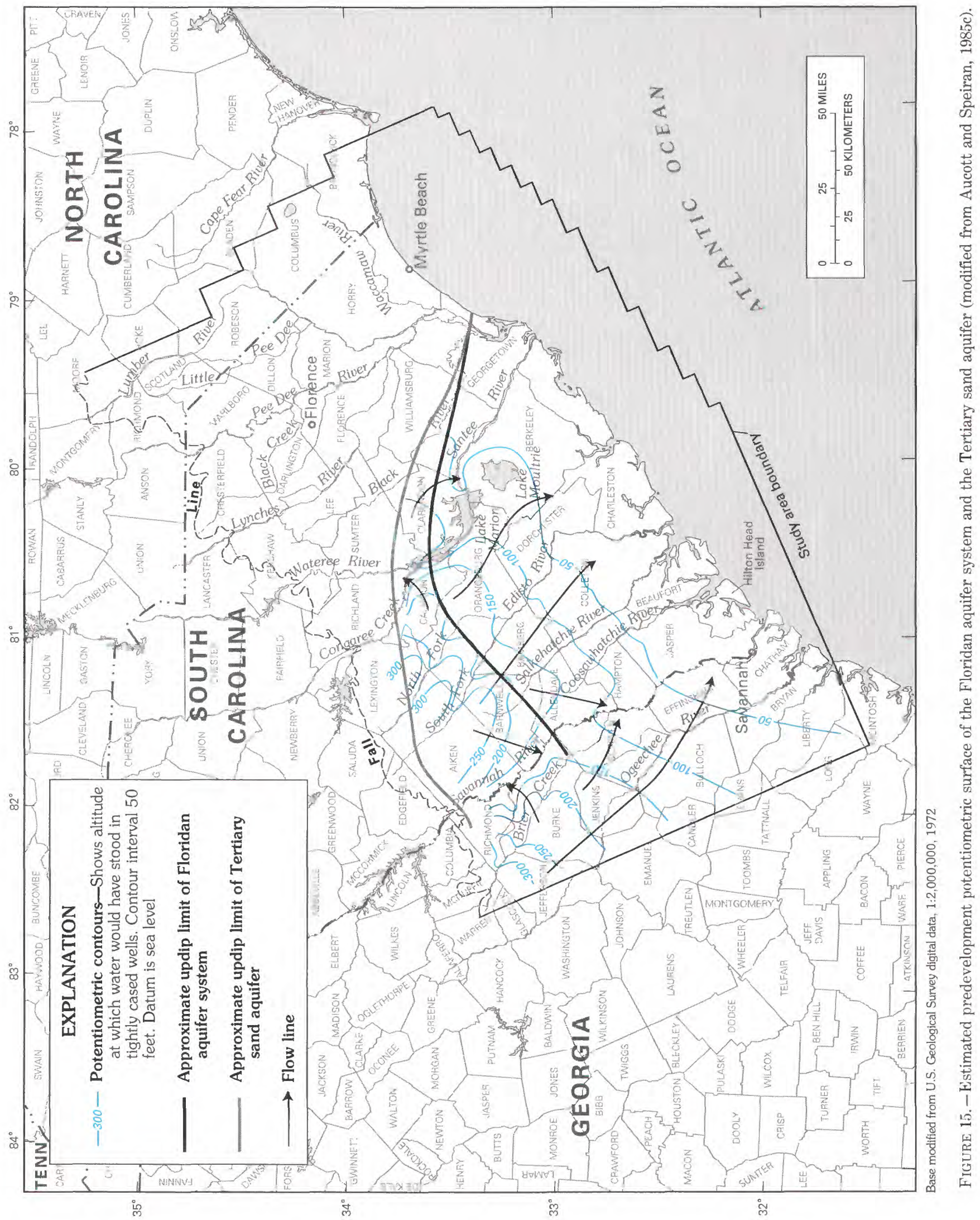




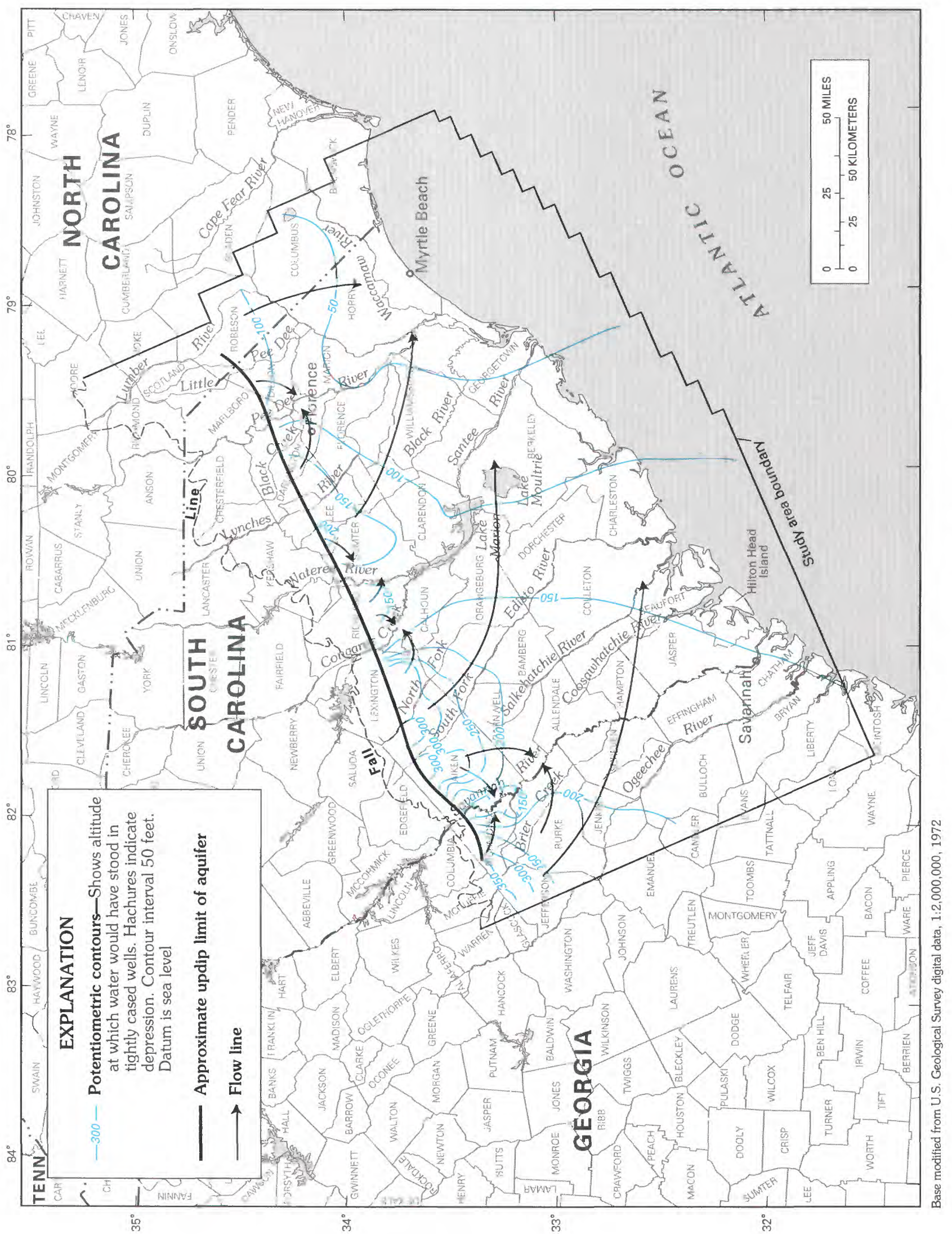

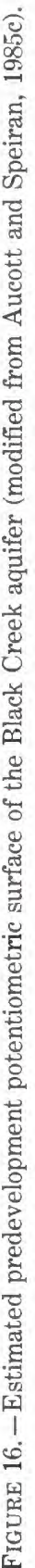




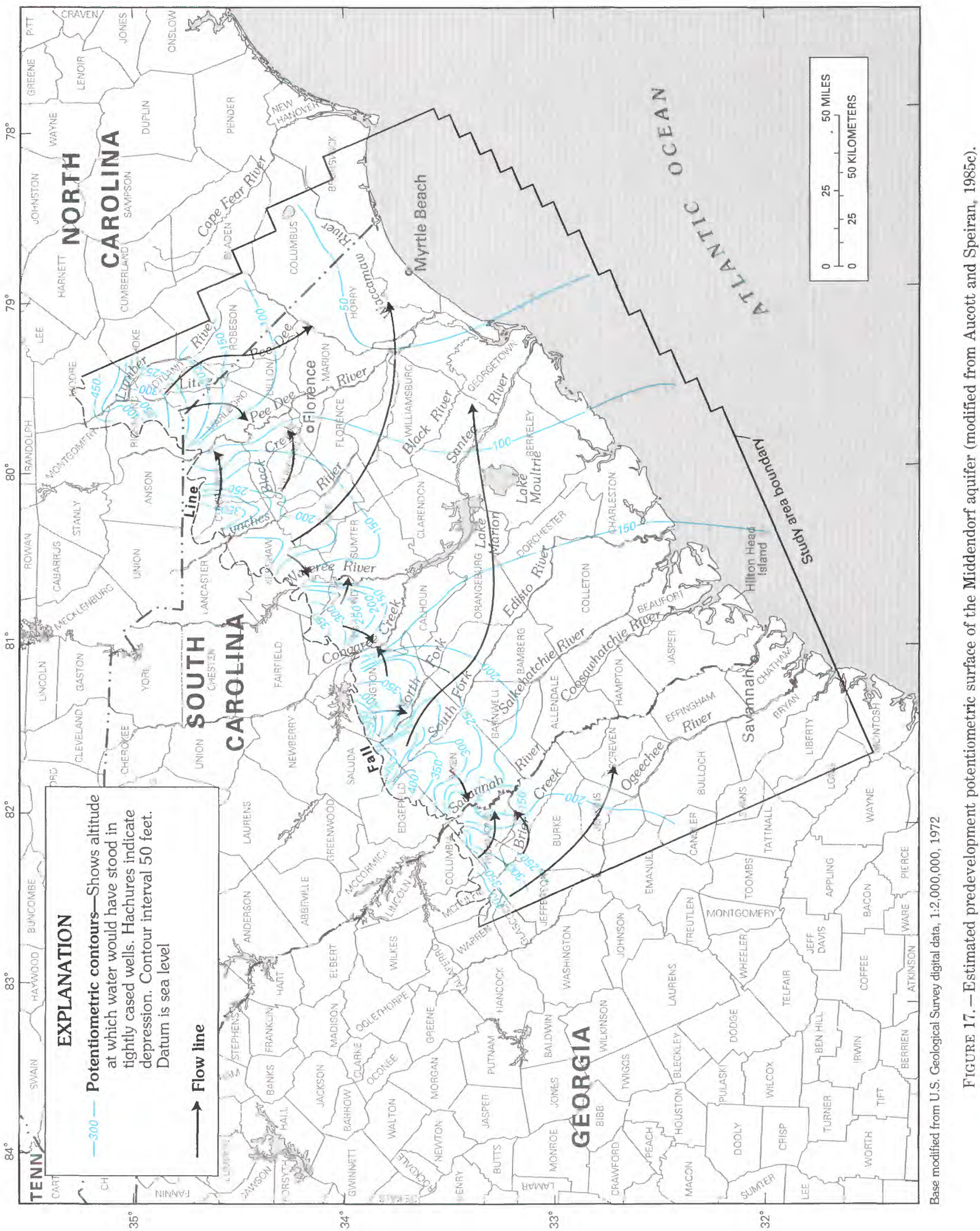




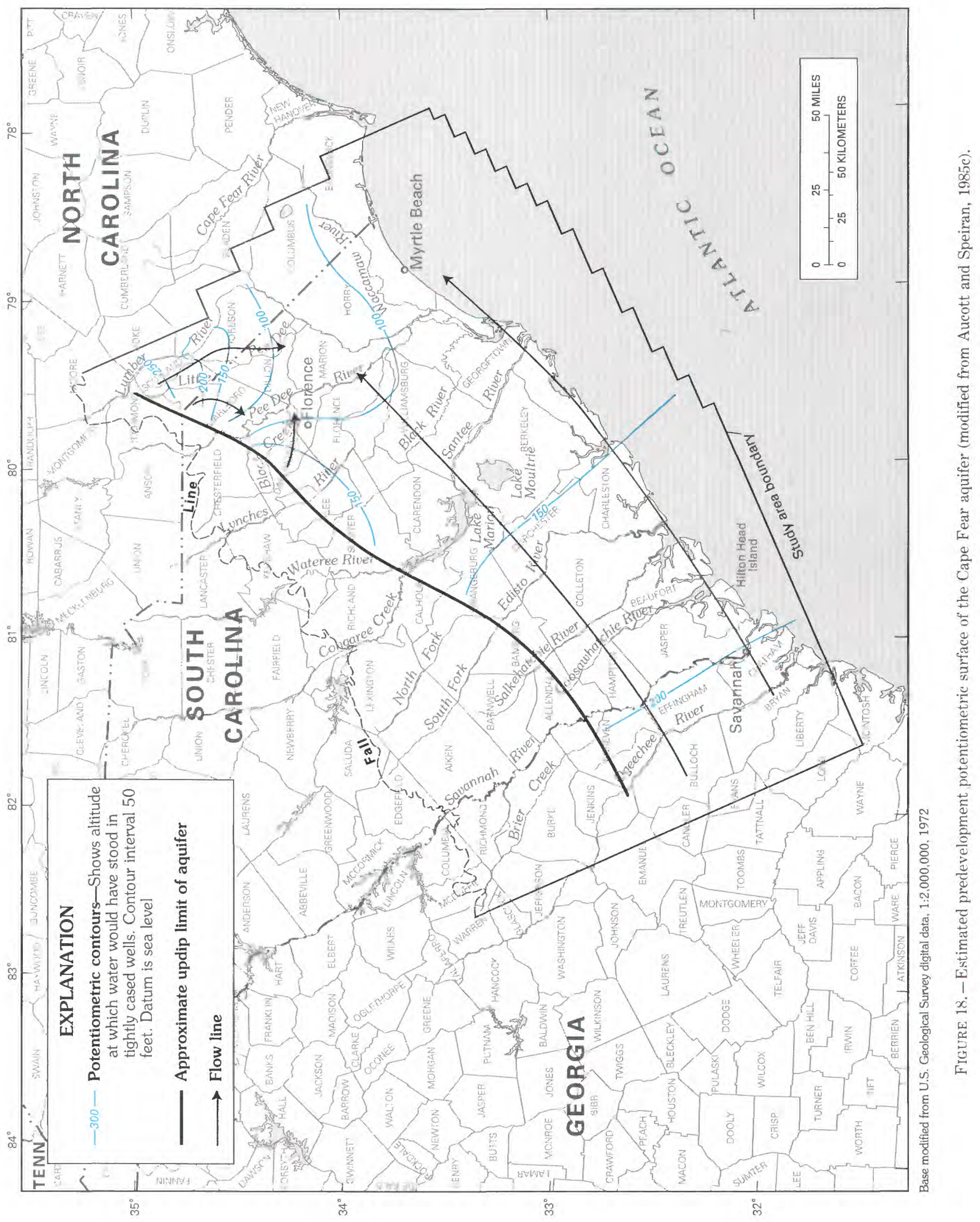


TABLE 2.-Low-flow characteristics of selected Coastal Plain streams in South Carolina

[Data from Bloxham, 1979]

\begin{tabular}{ccccccc}
\hline & Abbreviated & Drainage & Mean annual & 70\% duration & $90 \%$ duration & $99 \%$ duration \\
Station name & station & area & discharge & discharge & discharge & discharge \\
& no. & $\left(\mathrm{mi}^{2}\right)$ & {$\left[\left(\mathrm{ft}^{3} / \mathrm{s}\right) / \mathrm{mi}^{2}\right]$} & {$\left[\left(\mathrm{ft}^{3} / \mathrm{s}\right) / \mathrm{mi}^{2}\right]$} & {$\left[\left(\mathrm{ft}^{3} / \mathrm{s}\right) / \mathrm{mi}^{2}\right]$} & {$\left[\left(\mathrm{ft}^{3} / \mathrm{s}\right) / \mathrm{mi}^{2}\right]$} \\
\hline
\end{tabular}

Upper Coastal Plain

\begin{tabular}{llrrrrr}
\hline Edisto River near Branchville & 1740 & 1,720 & 1.18 & 0.70 & 0.46 \\
S. Fork Edisto River near Denmark & 1730 & 720 & 1.11 & .71 & .50 & .28 \\
N. Fork Edisto River at Orangeburg & 1735 & 683 & 1.17 & .76 & .53 & .32 \\
Little Pee Dee River near Dillon & 1325 & 524 & 1.10 & .52 & .30 & .11 \\
S. Fork Edisto River near Montmorenci & 1725 & 198 & 1.22 & .76 & .56 & .34 \\
Congaree Creek at Cayce & 1695.5 & 122 & 1.87 & 1.39 & 1.05 \\
Black Creek near McBee & 1309 & 108 & 1.62 & 1.02 & .52 \\
\hline
\end{tabular}

Upper and Lower Coastal Plain

\begin{tabular}{lrrrrrr}
\hline Little Pee Dee River at Galivants Ferry & 1350 & 2,790 & 1.17 & .47 & .25 & .10 \\
Edisto River near Givans & 1750 & 2,730 & .99 & .44 & .27 & .15 \\
Black River near Gable & 1355 & 401 & 1.00 & .39 & .09 & 0 \\
Salkehatchie River near Miley & 1755 & 341 & 1.02 & .50 & .28 & .13 \\
\hline
\end{tabular}

Lower Coastal Plain

\begin{tabular}{|c|c|c|c|c|c|c|}
\hline Black River near Kingstree & 1360 & 1,252 & .75 & .14 & .03 & .01 \\
\hline Waccamaw River near Longs & 1105 & 1,110 & 1.09 & .23 & .04 & .01 \\
\hline Coosawhatchie River near Hampton & 1765 & 203 & .94 & .13 & .02 & 0 \\
\hline
\end{tabular}

${ }^{1}$ See figure 19 for location of data-collection stations.

ric surfaces that existed under natural conditions prior to pumping from wells completed in the aquifers, and other human activities. Human effects on the ground-water flow system, as described prior to development, were minimal with the exception of the effects of two manmade lakes, Lake Marion and Lake Moultrie. The effect of these lakes on the ground-water system has been to raise the water levels in the Floridan aquifer systemTertiary sand aquifer (fig. 15), and in the surficial aquifer near the lakes. Minor head increases probably also occurred in the deeper aquifers as a result of the filling of the lakes in the 1940's.

The major source of recharge to the Coastal Plain aquifers under predevelopment and present-day conditions is precipitation in aquifer outcrop areas. Recharge in interstream areas resulted in highs on the predevelopment potentiometric surface near the updip limits of the Tertiary sand aquifer, the Black Creek aquifer, and the Middendorf aquifer (figs. 15 through 17, respectively).

Leakage through confining units between aquifers is also an important mechanism for recharge to the flow system. Downward leakage in the upper Coastal Plain, for example, in some parts of the area now occupied by the Savannah River Plant in Barnwell and Aiken Counties, S.C., provided an important source of recharge to the Black Creek aquifer and the Middendorf aquifer under predevelopment conditions (figs. 16 and 17). In some areas, downward leakage readily takes place because of the relatively high permeability of the confining units and a downward hydraulic gradient. In the western part of the upper Coastal Plain of South Carolina, downward leakage from the Tertiary sand aquifer is the principal source of recharge to the Black Creek and Middendorf aquifers.

Discharge from the aquifers is primarily to rivers in the upper Coastal Plain and by diffuse upward leakage to overlying aquifers in the lower Coastal Plain. Discharge from the Tertiary sand aquifer, the Black Creek aquifer, and the Middendorf aquifer is primarily to rivers in the vicinity of the aquifer outcrops in the upper Coastal Plain. Aquifer discharge to streams is relatively large in the upper Coastal Plain in comparison with discharge to lower Coastal Plain streams. Table 2 contains data for all streamflow stations totally within the Coastal Plain with drainage-basin areas greater than $100 \mathrm{mi}^{2}$ in South Carolina (Bloxham, 1979) (fig. 19). The data in table 2 clearly indicate that streamflow during low-flow periods is significantly greater for upper Coastal Plain streams than for lower Coastal Plain streams. Thus, aquifer discharge to streams is much larger in the upper than in the lower Coastal Plain. Upstream bending of the potentiometric-surface contours in the vicinity of the Savannah River and other major rivers (figs. 15 through 


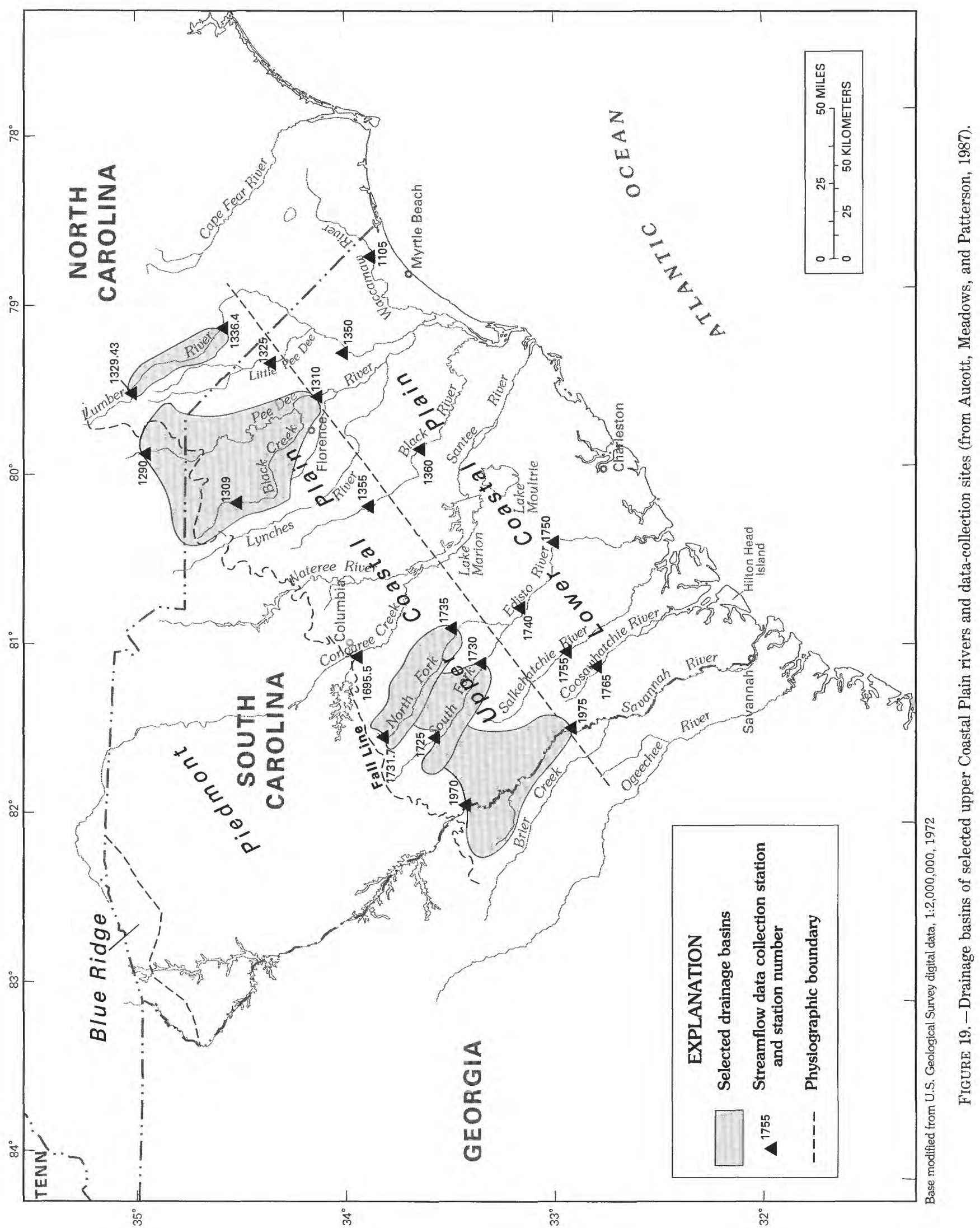


17) indicates discharge from the aquifers to the rivers (Siple, 1960; LeGrand and Pettyjohn, 1981). Discharge to smaller streams has less effect on the potentiometric surface than does discharge to large streams. This is not explicitly shown on the potentiometric-surface maps because of the map scale and data density.

In the lower Coastal Plain, discharge occurs from the Black Creek, the Middendorf, and the Cape Fear aquifers primarily by diffuse upward leakage to overlying aquifers. Flow quantities from upward leakage are small because of the low permeability of the confining units, particularly the one overlying the Black Creek aquifer. Water that is discharged by upward leakage eventually reaches the surficial aquifer or the Atlantic Ocean. If discharged to the surficial aquifer, the water eventually leaves the ground-water system by way of evapotranspiration or discharge to surface-water bodies.

In the upper Coastal Plain, most of the ground water in the Tertiary sand aquifer, the Black Creek aquifer, and the Middendorf aquifer flows from interstream recharge areas along short flow paths to rivers and small streams, where the water is discharged. In the lower Coastal Plain, where the aquifers are not hydraulically connected to streams, flow paths within each of the aquifers are much longer, and the lateral hydraulic gradients are lower than those in the upper Coastal Plain (figs. 15 through 17). A relatively small amount of ground water is not intercepted by upper Coastal Plain streams and flows downgradient to the lower Coastal Plain, where it discharges as diffuse upward leakage to overlying aquifers and ultimately to coastal marshes, rivers, and the ocean.

In the lower Coastal Plain, the direction of flow in the Floridan aquifer system and the Tertiary sand aquifer generally is perpendicular to the coast, and to a lesser degree, toward the major rivers (fig. 15). This flow differs markedly from the flow paths of the Black Creek and Middendorf aquifers, where water flows from the recharge areas toward the coast, then turns gradually eastward until it moves nearly parallel to the coast (figs. 16 and 17). Because of the reduced horizontal hydraulic gradient and generally finer sediments in the lower Coastal Plain, flow is slower in the Black Creek and Middendorf aquifers than in the upper Coastal Plain.

The direction of ground-water flow in the Floridan aquifer system and the Tertiary sand aquifer in the lower Coastal Plain is approximately perpendicular to flow in the Black Creek, Middendorf, and Cape Fear aquifers (compare fig. 15 with figs. 16 through 18). This difference in flow directions in the lower Coastal Plain is probably a result of differences in the degree of hydraulic connection between surface discharge points and each aquifer. The Floridan aquifer system and the Tertiary sand aquifer throughout much of their extent in the study area have relatively good hydraulic contact with the surficial aquifer and with rivers. The Black Creek and Middendorf aquifers in the lower Coastal Plain, in contrast, are in much more effective hydraulic contact with the surficial aquifer and streams in eastern South Carolina and southeastern North Carolina than in southwestern South Carolina (Aucott and Speiran, 1985b).

The distinctive flow pattern in the aquifers in Cretaceous rocks in the lower Coastal Plain is due to three factors. First, confining units above the Black Creek aquifer are more effective in inhibiting upward leakage in southwestern South Carolina (where clayey sediments of Paleocene age exist) than in eastern South Carolina (where the confining unit consists of more permeable sediments of the Peedee Formation). Second, because the dip of the Coastal Plain sediments in southeastern North Carolina is substantially less than the dip in southwestern South Carolina, the aquifers are closer to the land surface and in better hydraulic contact with the rivers farther downdip in the east than the west. Third, the Cape Fear River, and to a lesser extent the Pee Dee River, generally are more deeply incised farther upstream than rivers to the west. These river drains of lower altitude cause a lower potentiometric surface in the aquifers in Cretaceous rocks to the east. These three factors combined result in somewhat higher groundwater discharge from the Black Creek, Middendorf, and Cape Fear aquifers in the eastern part of the study area than in the southwestern part. This difference in discharge in the lower Coastal Plain causes a major alteration in the flow direction from perpendicular to the coast to nearly parallel to the coast toward the primary discharge area in southeastern North Carolina.

Ground-water flow in the Cape Fear aquifer differs from that in other aquifers (fig. 18). Sediments that are lateral equivalents of the Cape Fear aquifer are recharged from precipitation in outcrop areas and by downward leakage from overlying aquifers in areas in western Georgia (Stricker and others, 1985c). Water in these sediments moves eastward and northeastward in the subsurface of the Georgia Coastal Plain and flows laterally into the Cape Fear aquifer in South Carolina. The Cape Fear aquifer also is recharged by downward leakage from the Middendorf aquifer in the eastern upper Coastal Plain part of the study area, which accounts for the configuration of the potentiometric surface of the Cape Fear aquifer in the upper Coastal Plain. Discharge from the Cape Fear aquifer occurs as diffuse upward leakage to the Middendorf aquifer near the Pee Dee River in the upper Coastal Plain and throughout the lower Coastal Plain, especially in southeastern North Carolina. Flow in the lower Coastal Plain parts of the Cape Fear aquifer follows long flow paths from western Georgia along the South Carolina coast into 


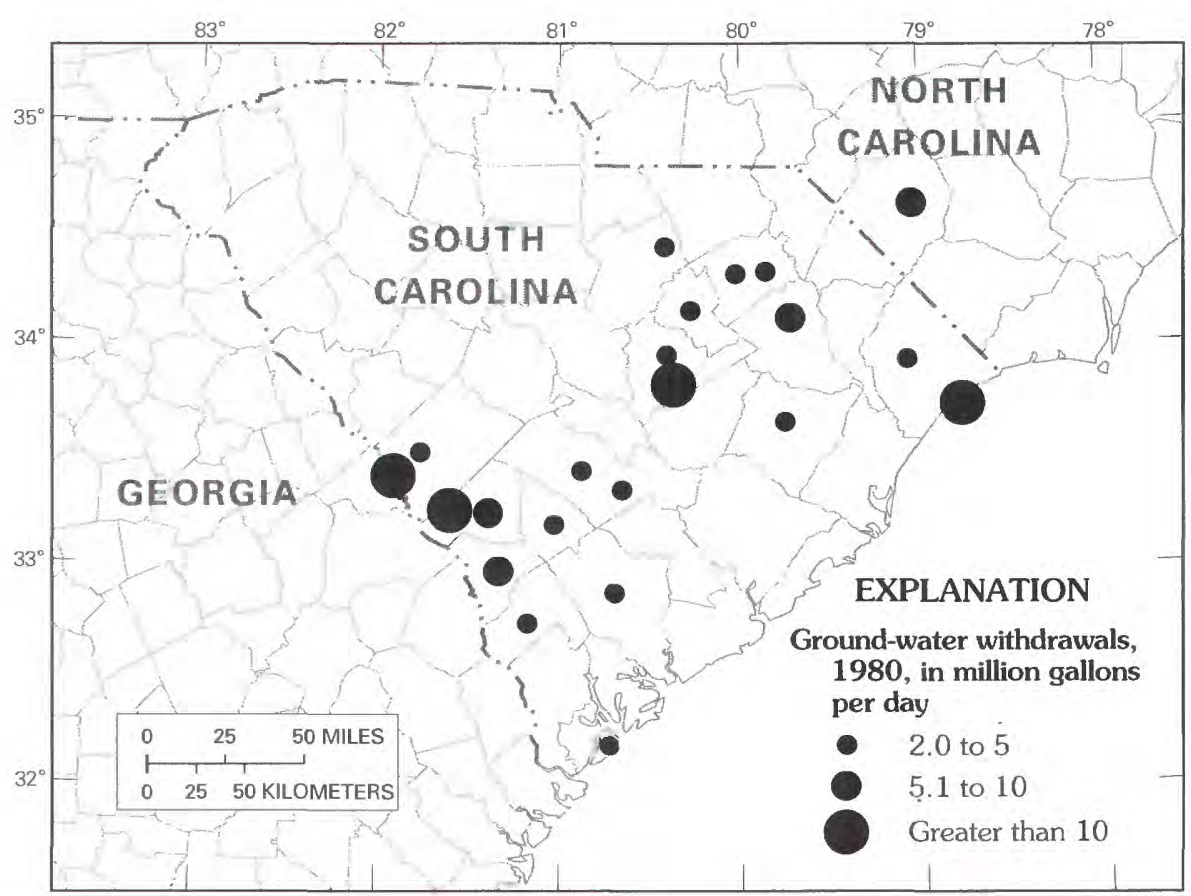

FIGURE 20. - Locations of ground-water withdrawals greater than 2 million gallons per day in 1980 in the South Carolina Coastal Plain and vicinity (modified from Lichtler and Aucott, 1985).

southeastern North Carolina. Because of the relatively low transmissivity of the Cape Fear aquifer and low hydraulic gradients in much of South Carolina, flow within it is sluggish.

\section{CHANGES IN THE FLOW SYSTEM AS A RESULT OF DEVELOPMENT}

Ground-water withdrawals from the Coastal Plain aquifers, particularly since the 1940 's, have altered the predevelopment flow system. However, the regional configuration of the potentiometric surfaces of the aquifers and the general directions of ground-water flow generally are similar for both predevelopment and present-day conditions. The areal distribution of the largest ground-water withdrawals in $\mathbf{1 9 8 0}$ is depicted in figure 20. The most significant withdrawals are for municipal and industrial uses in the cities of Sumter, Florence, and Myrtle Beach, S.C., and at the Savannah River Plant in Aiken and Barnwell Counties. These withdrawals have resulted in substantial drawdowns in some areas. In 1982 the amount of ground water used for irrigation was less than the amount used for municipal and industrial purposes. The combined effects of all withdrawals on the ground-water system are apparent from a comparison of the predevelopment potentiometric-surface maps (figs. 15 through 17 ) with potentiometric-surface maps for 1982 (figs. 21 through
23). The net declines in the potentiometric surfaces from predevelopment to 1982 conditions are shown on figures 24 through 26. All of these maps were developed from measured heads. The potentiometric surface of the Cape Fear aquifer was not mapped for 1982 conditions because the number of available data points was insufficient.

The greatest effects of pumping occur in the Middendorf and Black Creek aquifers in eastern South Carolina. Withdrawals from the Florence area of about 7 million gallons per day (Mgal/d) during 1980 and from the Myrtle Beach area of about $13 \mathrm{Mgal} / \mathrm{d}$ during 1980, as well as smaller withdrawals at Conway, Darlington, Kingstree, and other communities, have resulted in regional declines in head in these aquifers in eastern South Carolina (figs. 25 and 26). The declines were greater than $100 \mathrm{ft}$ in parts of the Black Creek aquifer near Myrtle Beach and greater than $150 \mathrm{ft}$ in the Middendorf aquifer in downtown Florence. Although head declines occur throughout much of eastern South Carolina, they are most pronounced in the vicinity of Florence in the Middendorf aquifer and in the vicinity of Myrtle Beach in the Black Creek aquifer. Head declines have occurred in the Middendorf aquifer in the Florence area beginning in the 1930 's (fig. 27). This trend has continued as pumpage has increased and the effects have extended farther from the center of pumping in the downtown Florence area. 


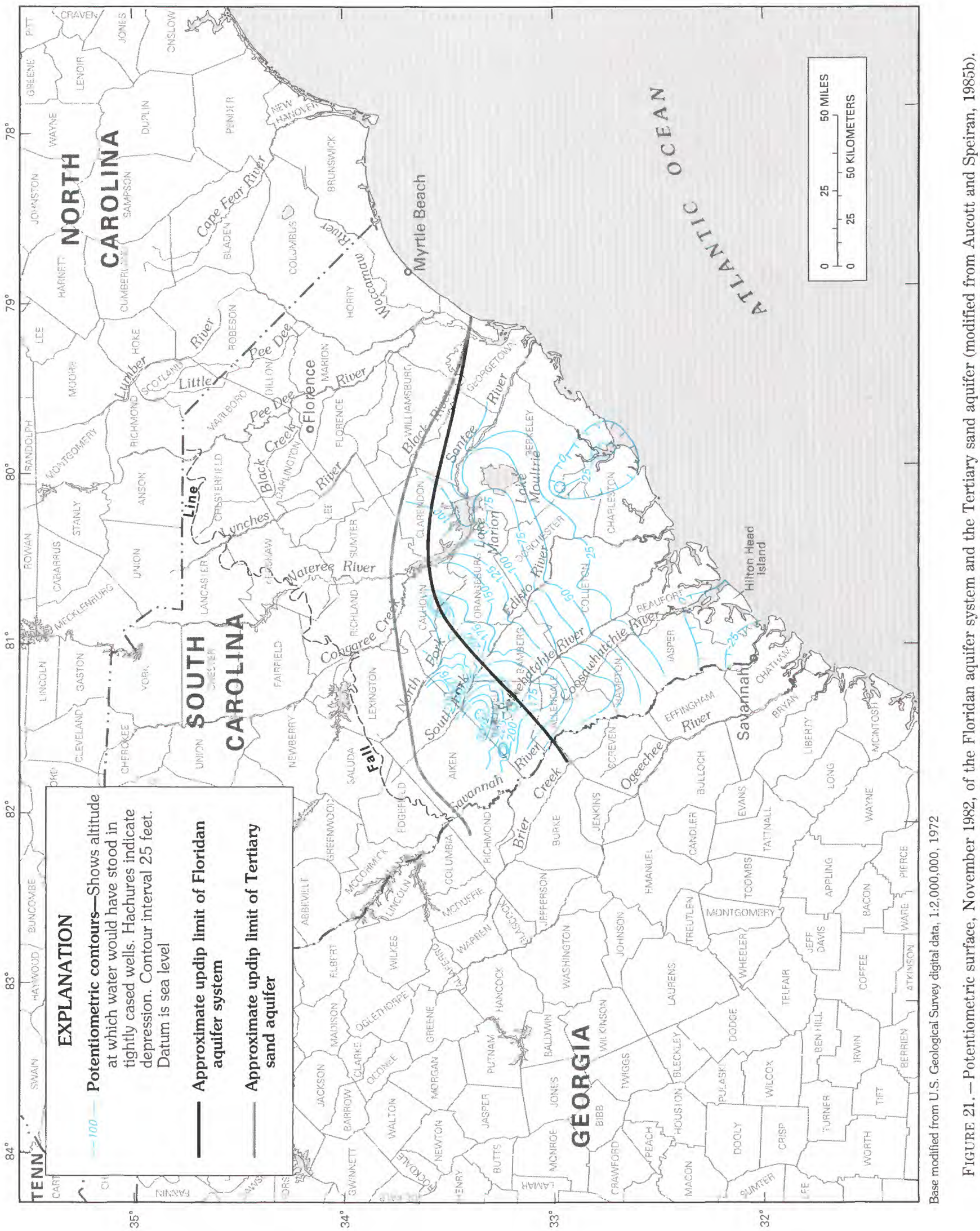




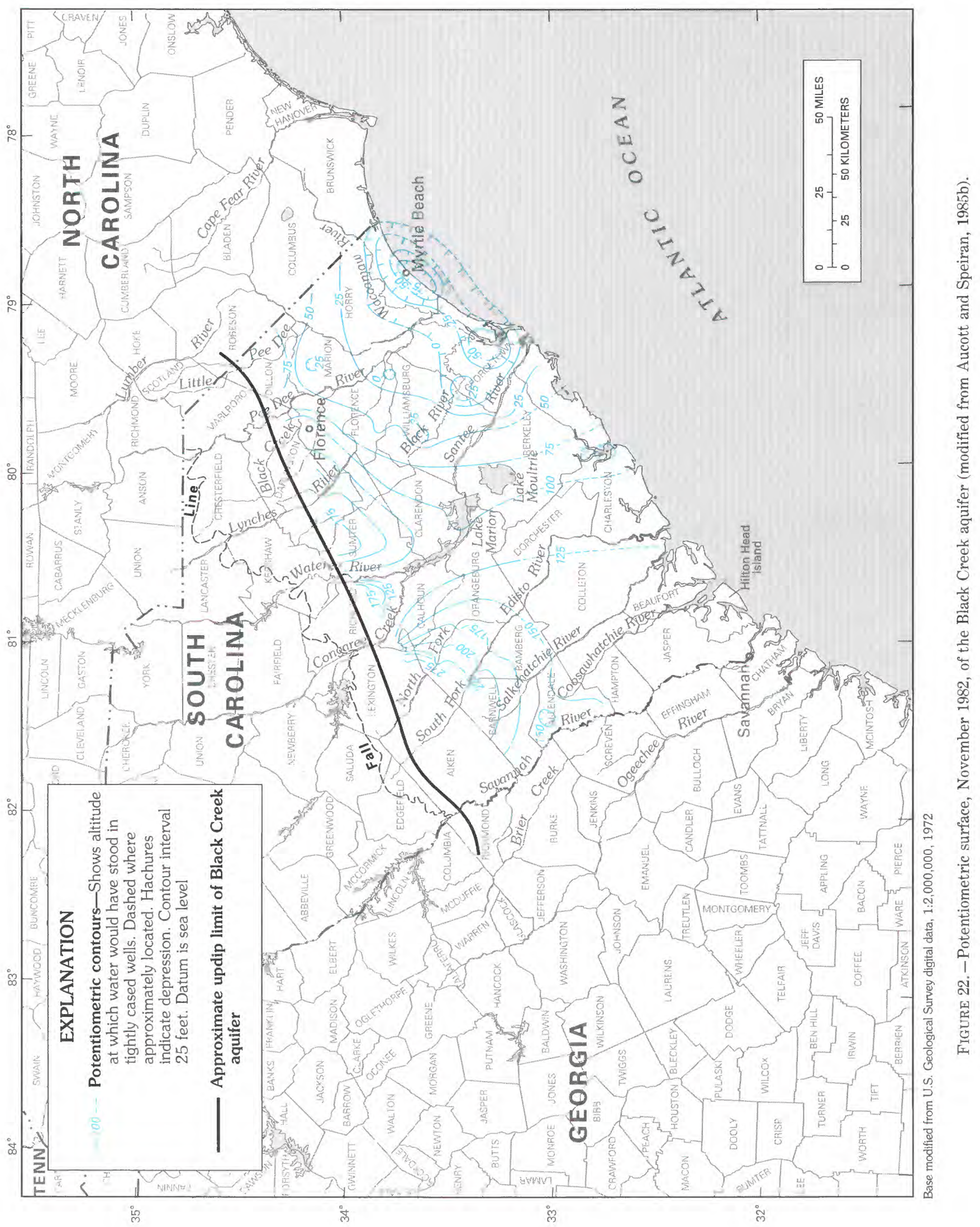




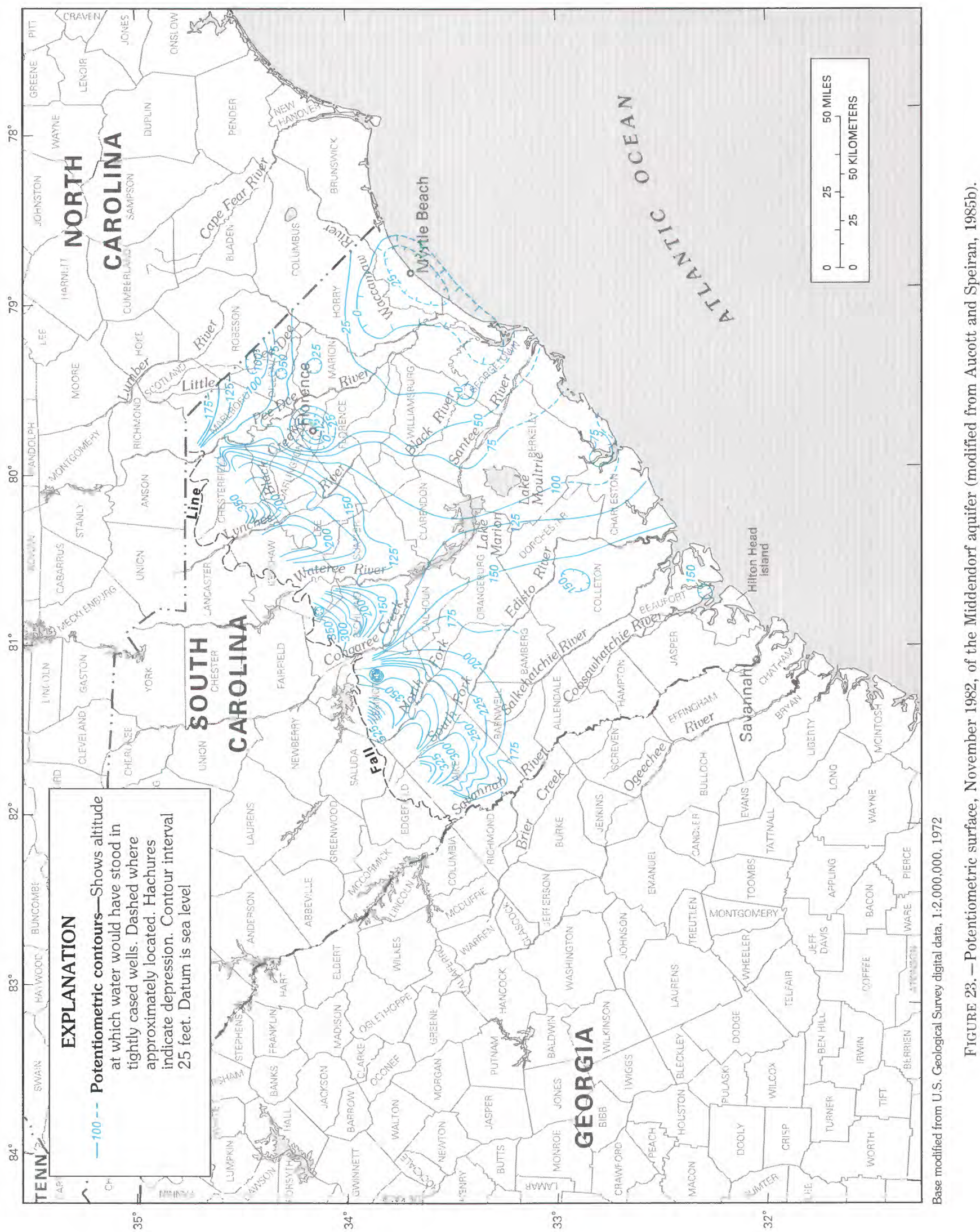




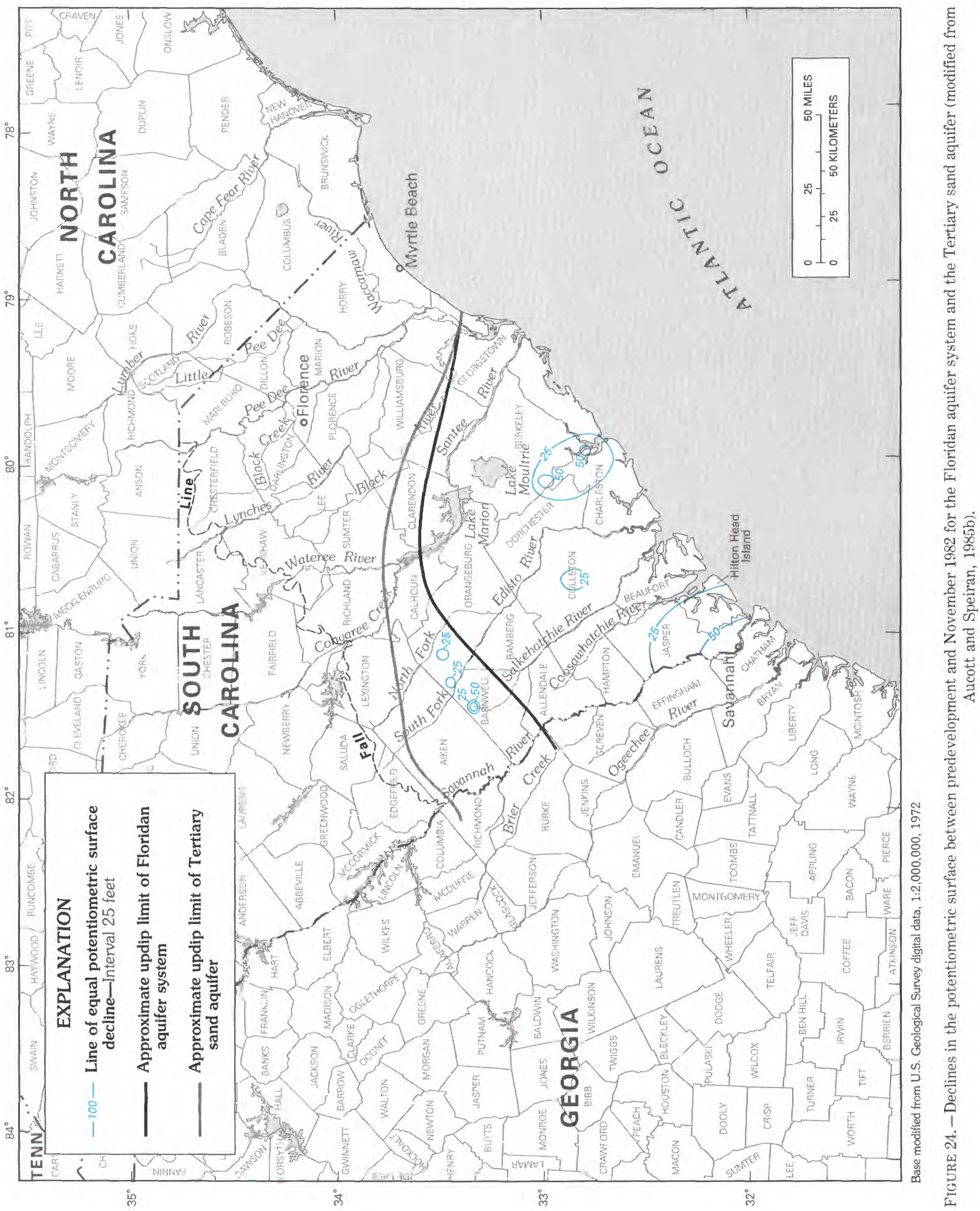




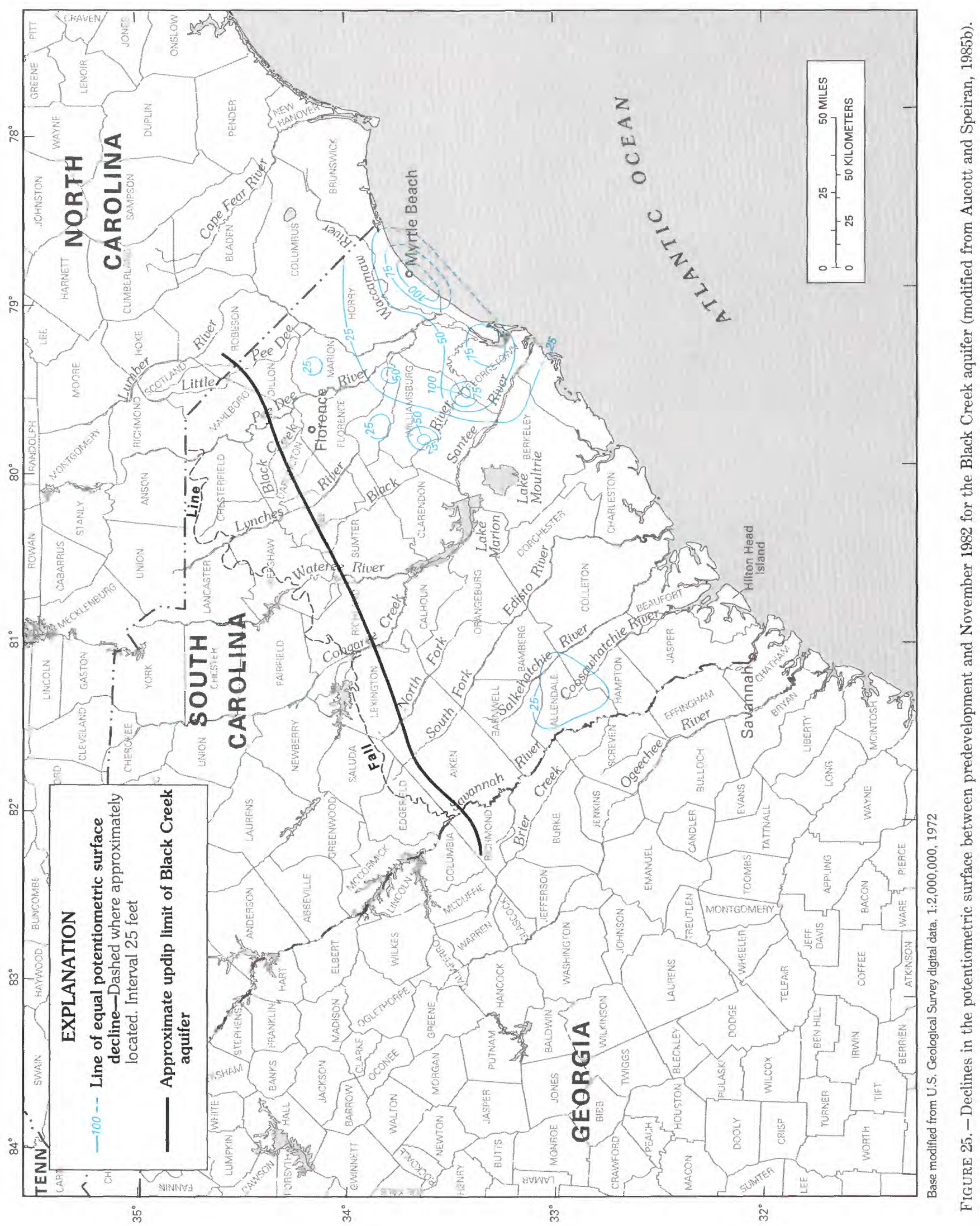




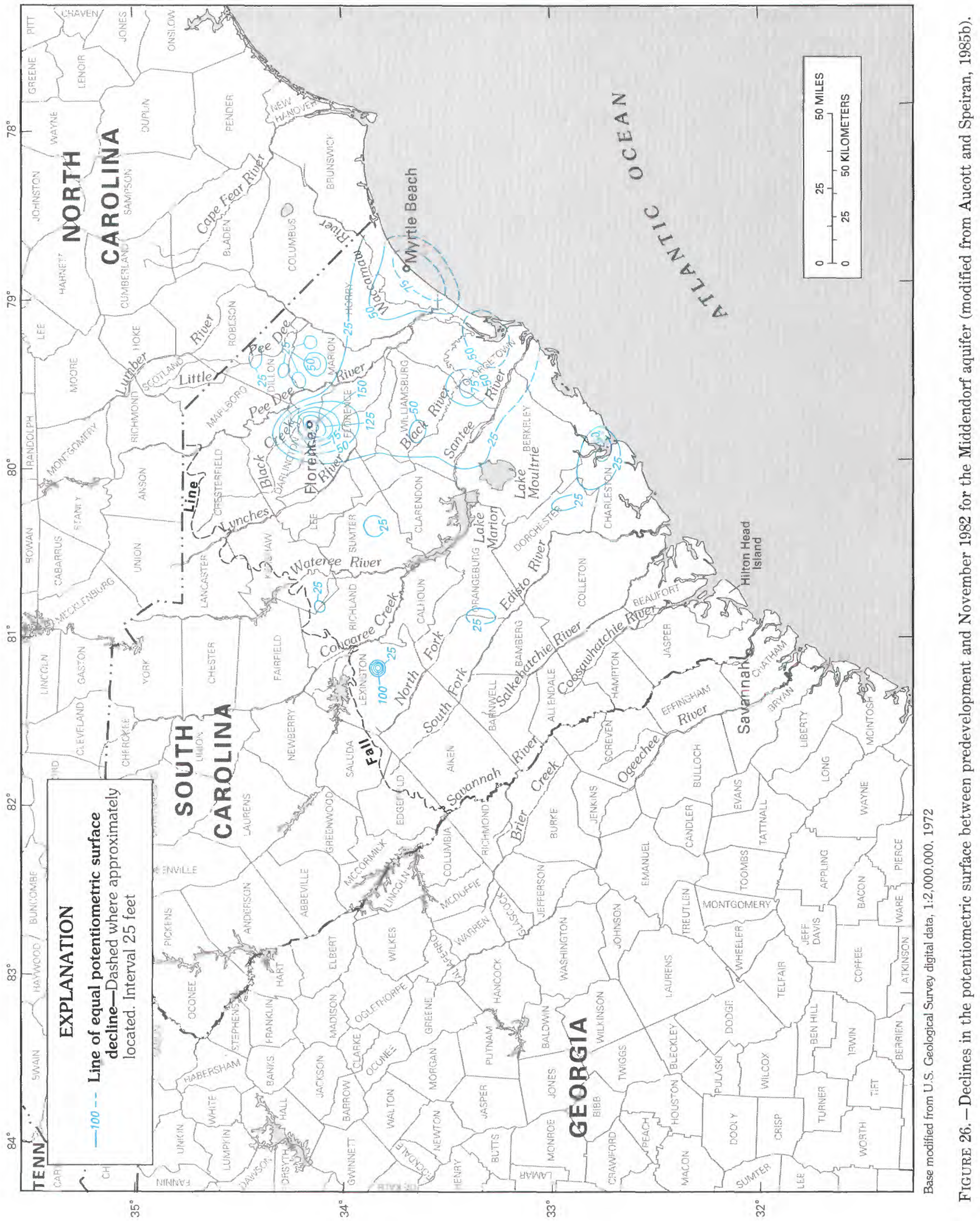




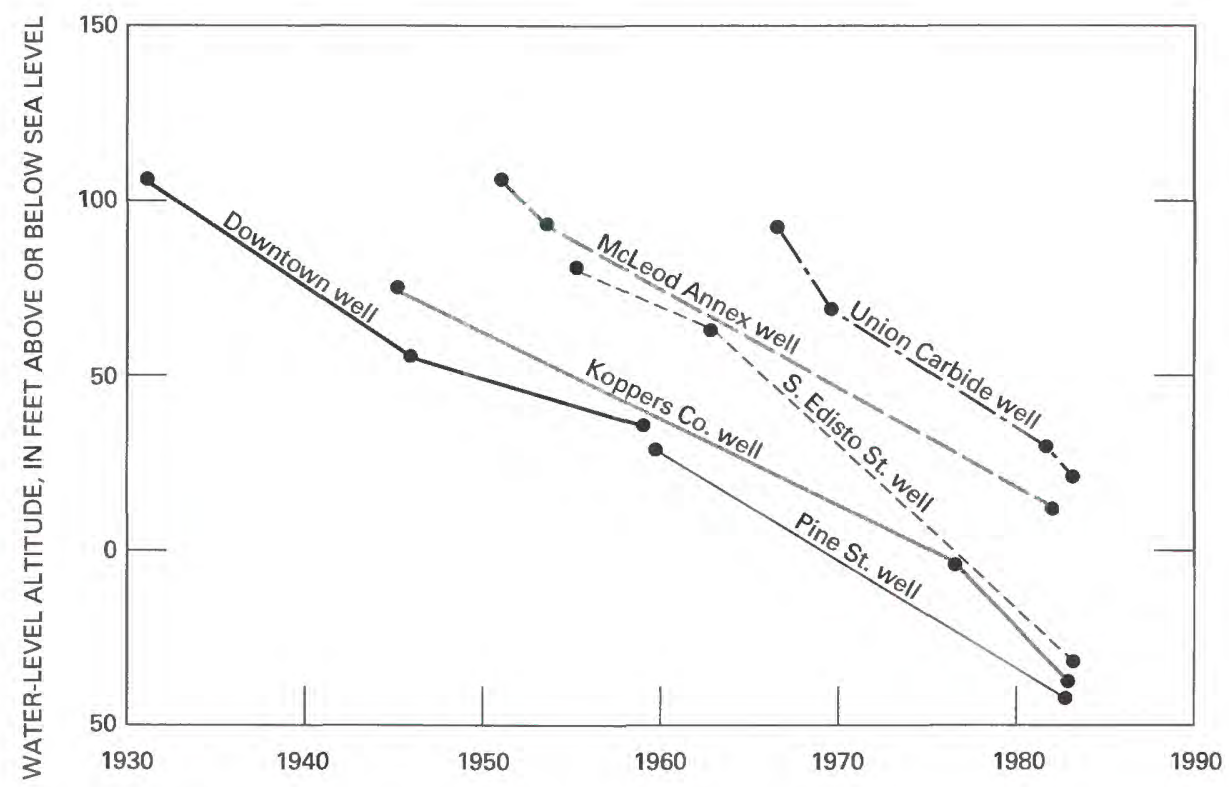

Figure 27. - Water-level declines for selected wells in the Middendorf aquifer near Florence, S.C. (modified from Aucott and Speiran, 1985a).

Withdrawals from the Middendorf and Black Creek aquifers at the city of Sumter (about $11 \mathrm{Mgal} / \mathrm{d}$ during 1980 ) and at the Savannah River Plant (about $10 \mathrm{Mgal} / \mathrm{d}$ during 1980) also have resulted in head declines, but these declines have been less severe than declines resulting from comparable withdrawals in the Florence and Myrtle Beach areas. This is probably because the transmissivities of these aquifers are considerably greater and the aquifers are closer to recharge sources at Sumter and the Savannah River Plant areas than in the Florence and Myrtle Beach areas.

Smaller head declines have occurred in other areas in the Black Creek aquifer. The declines in the Allendale County area mostly result from irrigation and industrial withdrawals in the county.

Smaller head declines have also occurred in other places due to withdrawals from the Middendorf aquifer. Declines in the Charleston-Summerville area are a result of relatively small withdrawals, mostly for municipal supply, from the Middendorf aquifer in the SummervilleCharleston area. Withdrawals from a few industrial wells to the north of Charleston, as well as some old wells in the city of Charleston, probably also contribute to these declines. A deep well at Fort Moultrie near Charleston is discharging water from the Middendorf aquifer through casing breaches into shallower units with lower heads. These breaches probably developed as a result of long exposure to corrosive water present in some shallower zones. Interaquifer leakage through breached casings may be more widespread in Charleston due to the large number of old wells, some of which were constructed in the late 1800 's and may not have been properly plugged when abandoned.

Although general flow patterns have not been greatly changed in the Black Creek and Middendorf aquifers as a result of withdrawals, some notable regional changes have occurred (figs. 22 and 23). In Horry and Georgetown Counties prior to development, the vertical head gradient was upward toward land surface. Now, however, the gradient is toward the Black Creek aquifer from above and below. Withdrawals have altered flow patterns somewhat in the Middendorf aquifer in Florence, Darlington, and Charleston Counties, and in the vicinity of other smaller withdrawal centers.

The potentiometric surface of the Floridan aquifer system has been affected by pumping from the Floridan aquifer system in the Charleston area and in the area around the city of Savannah (figs. 21 and 24). Although withdrawals from the Floridan in the Charleston area are difficult to quantify, a decline in the potentiometric surface of greater than $50 \mathrm{ft}$ has occurred in places. Ground-water withdrawals from the Floridan in the Savannah area were about $79 \mathrm{Mgal} / \mathrm{d}$ during 1980 (Krause and Randolph, 1989). These withdrawals have created a widespread decline in the potentiometric surface in Savannah and vicinity (Matthews and others, 1982). Head declines in the Savannah and Charleston areas have resulted in significant changes in flow patterns in those areas (fig. 21). A reversal in the vertical head gradient has occurred-prior to development, the gradient was upward from the Floridan to the surficial aquifer; in 1982, the gradient was downward from the 
surficial aquifer toward the Floridan aquifer system. Smaller, localized head declines also have occurred updip in the Tertiary sand aquifer as a result of less concentrated pumping in smaller cities like Williston and Springfield.

\section{WATER QUALITY AND GENERAL GEOCHEMISTRY}

Ground water in aquifer outcrop areas in the upper Coastal Plain generally contains low concentrations of dissolved solids, is poorly buffered, and has no dominant major chemical constituents. As water flows through the aquifer system, three major geochemical processes alter the quality of the ground water.

One major process is an increase in the concentration of inorganic carbon in the form of bicarbonate ions. The most important source of inorganic carbon is the dissolution of carbonate minerals (shell material and calcite) by carbonic acid and hydrolysis (Aucott and Speiran, 1986; Speiran and Aucott, 1991). Dissolution commonly occurs in parts of the aquifers containing calcareous sediments and results in greater buffering of water in these parts of the aquifers. Dissolution of carbonate minerals also contributes to the amount of calcium in solution. The calcium may remain in solution or be involved in subsequent geochemical processes.

The second process involves calcium, produced from the dissolution of carbonate minerals, which exchanges for sodium present in sodium-rich clay minerals (Zack, 1980), particularly in clastic aquifers. This ion exchange process results in significant increases in the concentrations of sodium in ground water while maintaining low concentrations of calcium. Exchange of calcium for sodium has little effect on the water chemistry in the Floridan aquifer system, which contains primarily carbonate sediments and few sodium-rich clays.

High concentrations of sodium and chloride in ground water occur where the aquifers contain dilute or concentrated seawater. This occurs where the third process, the mixing of freshwater and saltwater, takes place. The location of seawater in the aquifers is influenced by three factors: (1) the presence of seawater that is still being flushed after the last Pleistocene transgression of the sea, (2) proximity to the equilibrium position of the freshwater-saltwater interface, and (3) recent movement of the interface in response to human stress on the flow system. Unflushed seawater typically is found toward the end of regional flow paths in deep parts of the flow system and extends farther inland in aquifers with low transmissivity and thus longer flushing times. The freshwater-saltwater interface, defined in this report as the point at which ground water contains dissolved-solids concentrations of 10,000 milligrams per liter $(\mathrm{mg} / \mathrm{L})$ expressed as sodium chloride (Lee and others, 1985), generally is located off the coast of South Carolina. However, brackish water occurs in aquifers beneath the onshore parts of the study area in places.

The effects of these processes can be shown on maps (figs. 28 through 34 ) depicting the dominant chemical constituents and concentrations of dissolved solids and chloride for water from the aquifers. The surficial and Cape Fear aquifers are not discussed because of the local variability of the former and lack of data for the latter aquifer.

There is no consistently dominant chemical constituent in water from the Middendorf aquifer in its outcrop area (fig. 28), although concentrations of silica frequently account for 25-50 percent of the dissolved solids. Dissolved-solids concentrations of less than $100 \mathrm{mg} / \mathrm{L}$ characterize water in the outcrop areas (fig. 29). Downgradient, dissolution of carbonate minerals and exchange of sodium for calcium occurs, and sodium and bicarbonate ions are dominant. Sodium and chloride ions are dominant in a small area near the end of the ground-water flow path in the Middendorf aquifer (fig. 33) in the eastern part of the lower Coastal Plain of South Carolina and southeastern North Carolina. This is probably the result of mixing of freshwater with incompletely flushed seawater.

Differences in the concentrations and distribution of major constituents occur between waters in the Black Creek and Middendorf aquifers because of differences in the mineralogy of the aquifer sediments. Calcareous sediments are absent in much of the upper Coastal Plain part of the Middendorf aquifer, but are present in the lower Coastal Plain part of the Middendorf aquifer and throughout most of the Black Creek aquifer. Accordingly, the dissolution of carbonate minerals and exchange of sodium for calcium result in a sodium-bicarbonate-type water farther up the flow paths (closer to the updip limit of the aquifer) in the Black Creek aquifer (fig. 30) than in the Middendorf aquifer (fig. 28). As a result, the area of water having low concentrations of dissolved solids and no major dominant constituent is smaller in the Black Creek aquifer (figs. 30 and 31) than in the Middendorf aquifer (figs. 28 and 29). This is particularly noticeable in the eastern part of the upper Coastal Plain, where the Black Creek aquifer is highly calcareous.

Along the coast, larger areas are characterized by sodium-chloride-type water in the Black Creek aquifer than in the Middendorf aquifer. This may be due in part to the relatively low hydraulic conductivity of the Black Creek aquifer along the southern half of the coastal area. More time is required for brackish or saline water to be completely flushed from sediments having lower permeability. As a result, mixed freshwater and seawater is 


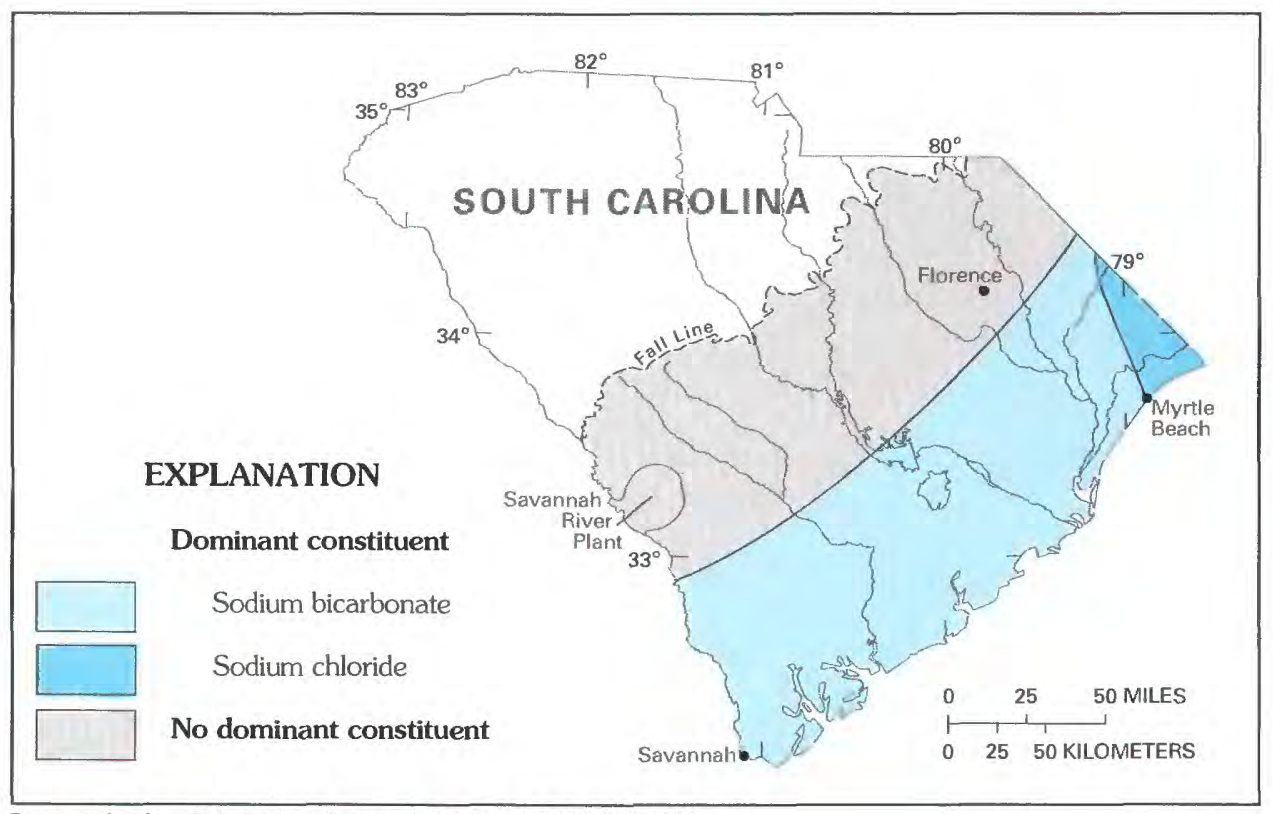

Base modified from U.S. Geological Survey digital data, 1:2,000,000, 1972

Figure 28. - Dominant chemical constituents in water from the Middendorf aquifer (from Aucott and Speiran, 1986).

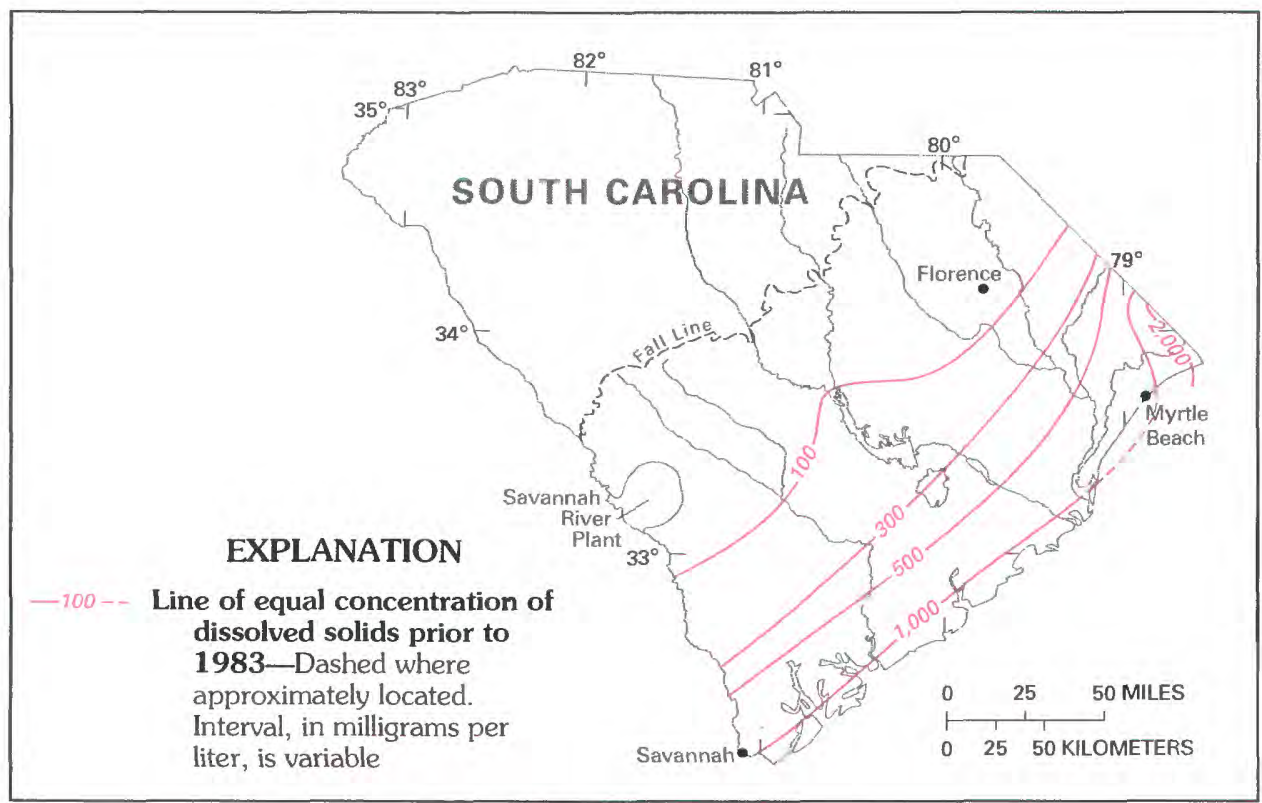

Base modified from U.S. Geological Survey digital data, 1:2,000,000, 1972

Figure 29. - Concentrations of dissolved solids in water from the Middendorf aquifer (from Aucott and Speiran, 1986).

present to a greater degree inland in the Black Creek aquifer than the Middendorf aquifer.

In the Tertiary sand aquifer, where the sediments are primarily noncalcareous sand and clay, the quality of the water is similar to that found in the updip part of the
Middendorf aquifer: low concentrations of dissolved solids (less than $100 \mathrm{mg} / \mathrm{L}$ ) and no dominant chemical constituent (fig. 32). In the Floridan aquifer system, the sediments are predominantly limestone and the water is a calcium bicarbonate type. Because little sodium-rich 


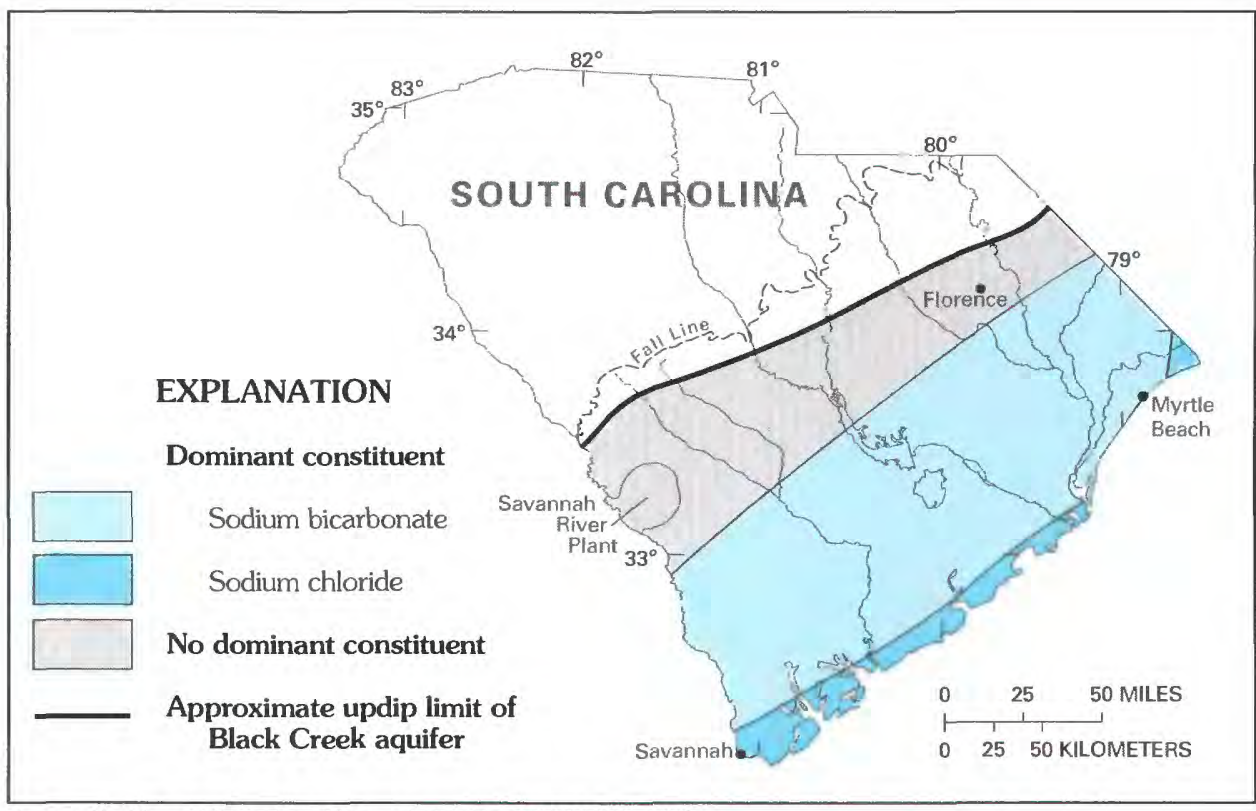

Base modified from U.S. Geological Survey digital data, 1:2,000,000, 1972

FIGURE 30.-Dominant chemical constituents in water from the Black Creek aquifer (from Aucott and Speiran, 1986).

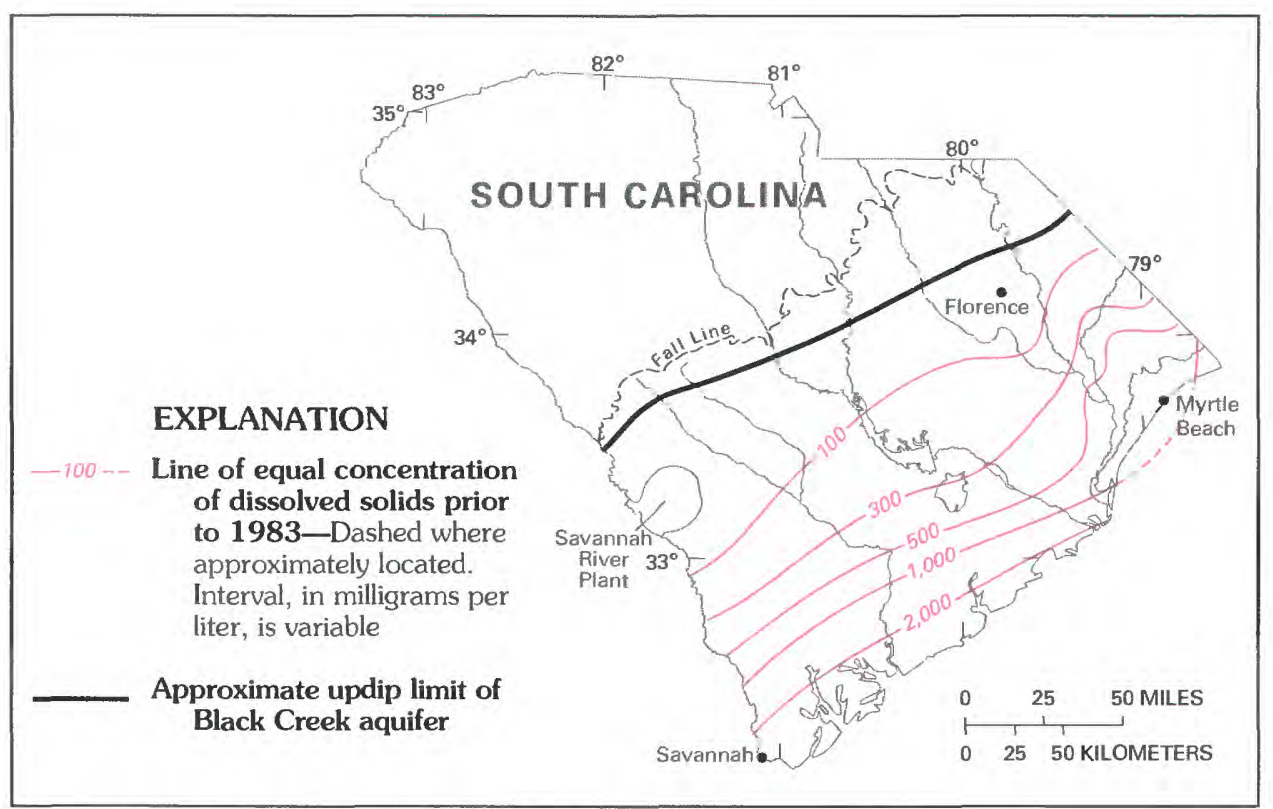

Base modified from U.S. Geological Survey digital data, 1:2,000,000, 1972

FIGURE 31. - Concentrations of dissolved solids in water from the Black Creek aquifer (from Aucott and Speiran, 1986).

clay is present in the Floridan aquifer system, calcium and bicarbonate remain the dominant constituents downgradient except near the coast and at the freshwatersaltwater interface, where the water is a sodium chloride type.
Locally, ground water in the Coastal Plain aquifers of South Carolina contains high concentrations of chloride, fluoride, and iron; has a low $\mathrm{pH}$; and may be contaminated from surface sources. These anomalies are due to local variations in mineralogy, hydrologic conditions, or 


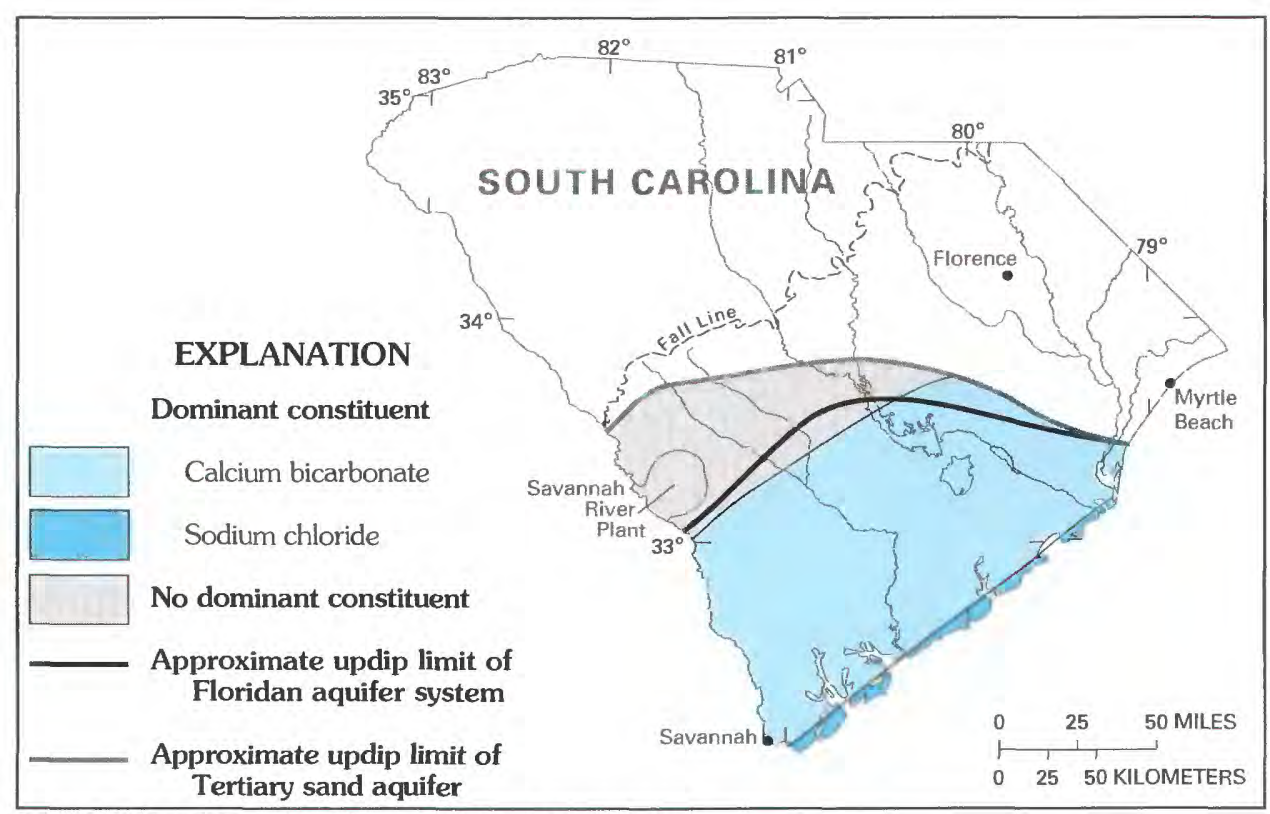

Base modified from U.S. Geological Survey digital data. 1:2.000,000, 1972

FIGURE 32.-Dominant chemical constituents in water from the Floridan aquifer system and the Tertiary sand aquifer (modified from Aucott and Speiran, 1986).

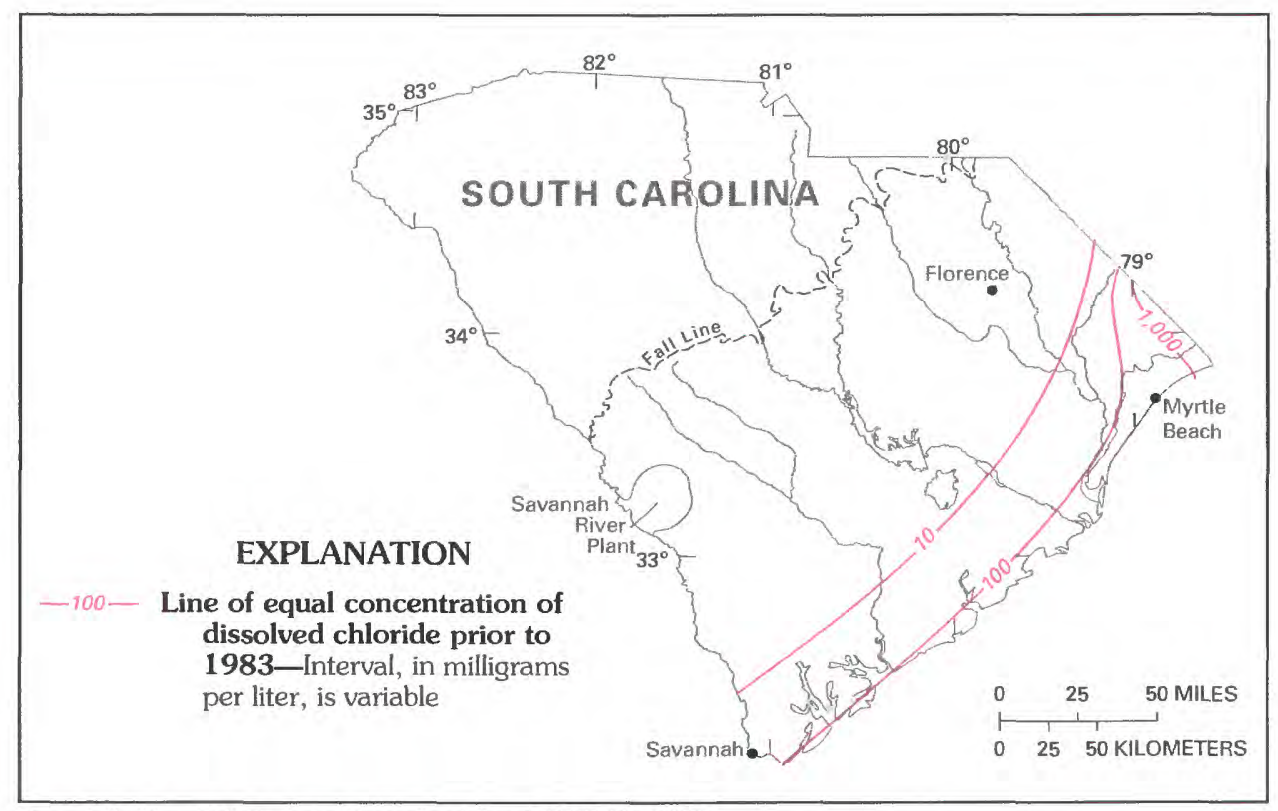

Base modified from U.S. Geological Survey digital data, 1:2,000,000, 1972

FIGURE 33. - Concentrations of dissolved chloride in water from the Middendorf aquifer (modified from Aucott and Speiran, 1986).

sources of contamination. Concentrations of chloride greater than $1,000 \mathrm{mg} / \mathrm{L}$ occur in water from the Black Creek and Middendorf aquifers (figs. 33 and 34). These large concentrations are the result of the mixing of freshwater with brackish or saline water that has not been completely flushed from the aquifer system, or as a result of proximity to the modern freshwater-saltwater interface. Because changes in concentrations of chloride near this interface are gradational, water from wells located near the interface on the freshwater side may 


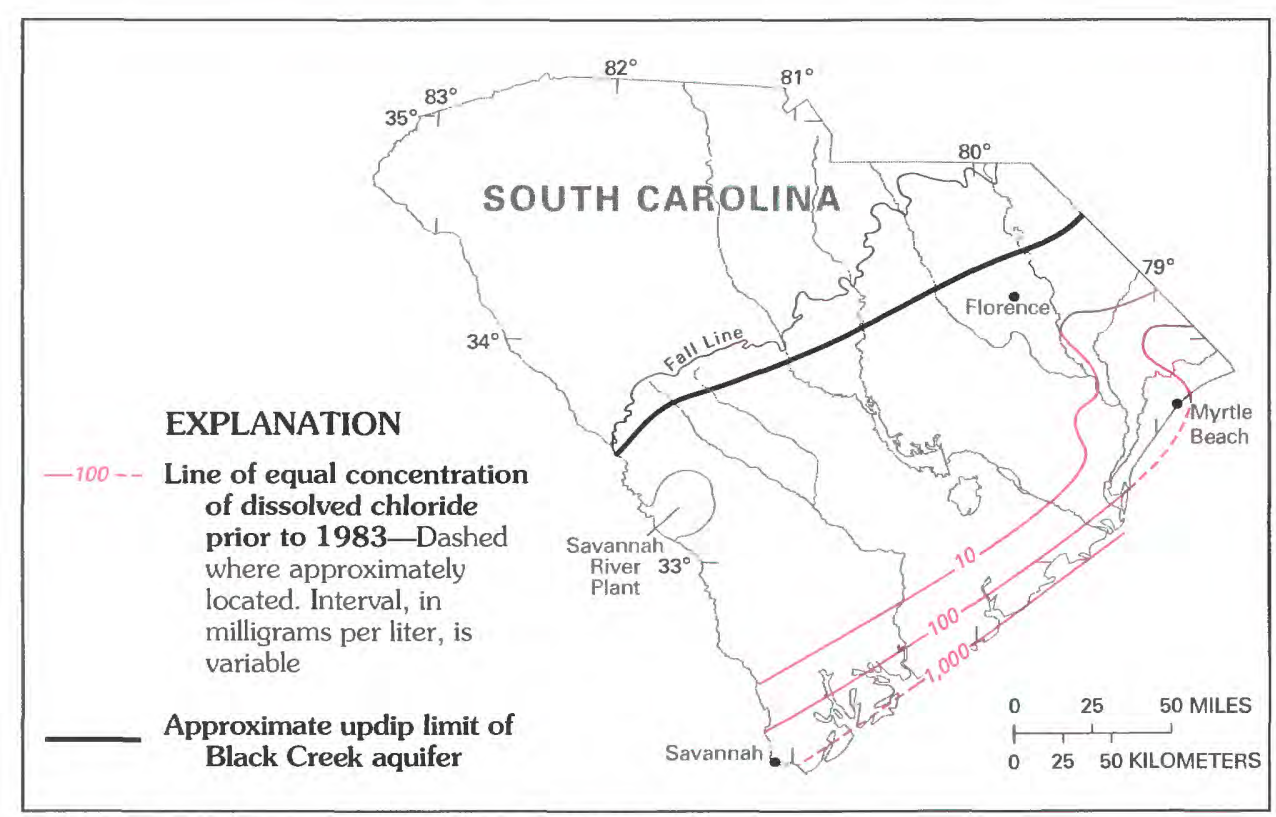

Base modified from U.S. Geological Survey digital data, 1:2,000,000, 1972

FIGURE 34. - Concentrations of dissolved chloride in water from the Black Creek aquifer (from Aucott and Speiran, 1986).

have concentrations that exceed the secondary maximum contaminant level of $250 \mathrm{mg} / \mathrm{L}$ for chloride (U.S. Environmental Protection Agency, 1986b). Pumping water from an aquifer in the vicinity of this interface may result in saltwater encroachment as the interface moves toward the pumping center. Although major saltwater encroachment has not been identified to date (1990) in South Carolina, the potential for encroachment exists, particularly in the Myrtle Beach (Black Creek aquifer), Hilton Head Island (Floridan aquifer system), and Isle of Palms-Sullivans Island areas (Middendorf aquifer), where large amounts of ground water are being withdrawn near the coast.

Fluoride in ground water in South Carolina results from an ion exchange reaction involving fluorapatite in fossilized shark teeth, which are abundant in the Black Creek aquifer (Zack, 1980) and are common in the Middendorf aquifer. Concentrations of fluoride are greater than the $1.4 \mathrm{mg} / \mathrm{L}$ maximum contaminant level (U.S. Environmental Protection Agency, 1986a) in water from the Black Creek and Middendorf aquifers in many parts of the lower Coastal Plain. Such concentrations of fluoride may cause mottling of teeth. Treatment of water to remove excess fluoride is expensive and generally is not practiced.

Concentrations of iron exceed the secondary maximum contaminant level of $0.3 \mathrm{mg} / \mathrm{L}$ (U.S. Environmental Protection Agency, 1986b) in water from shallow wells in much of the area and from deep parts of the Middendorf and Black Creek aquifers in the lower part of the upper
Coastal Plain. These high concentrations of iron probably are a result of the dissolution of iron from sandy sediments in a reducing environment by waters having a low pH (G.K. Speiran, U.S. Geological Survey, oral commun., 1985). Concentrations of iron greater than 0.3 $\mathrm{mg} / \mathrm{L}$ result in scale, stain, and taste problems. Treatment for excessive iron is expensive but commonly is applied to waters used for public supplies and is locally applied to many domestic supplies where concentrations of iron are high.

The $\mathrm{pH}$ of ground water is less than the secondary maximum contaminant level of 6.5 (U.S. Environmental Protection Agency, 1986b) throughout much of the upper Coastal Plain, where concentrations of dissolved solids and bicarbonate are low and the ground water is poorly buffered. Corrosion problems occur where waters have a $\mathrm{pH}$ less than about 6.0. In water-treatment systems, lime is commonly added to the water in order to increase the $\mathrm{pH}$ and to prevent corrosion of distribution systems.

\section{SIMULATION OF THE GROUND-WATER FLOW SYSTEM}

\section{APPROACH}

As mentioned previously, regional and statewide RASA studies were conducted for areas that adjoin or overlap this study area. Among the adjoining studies were investigations performed for the Coastal Plain of Georgia and North Carolina. Digital ground-water flow 
models were constructed for each of these studies. Adjacent statewide modeling efforts that overlapped this study area are shown in figure 2 . A model constructed for the study of the Floridan aquifer system also overlapped a part of South Carolina and will be discussed later in this report. Data and results were exchanged and discussed with others involved in adjoining and overlapping RASA studies, particularly those involved in overlapping statewide studies.

Two digital ground-water flow models were constructed during this study to aid in understanding the ground-water flow system, to help determine the areal distribution of aquifer parameters in the Coastal Plain aquifer system of South Carolina and nearby areas, and to evaluate the effects of withdrawals on the groundwater flow system. The first model simulated the predevelopment flow system under steady-state conditions and has been previously documented in detail (Aucott, 1988). The predevelopment model was used as a starting point for the second model, which simulated transient changes in the flow system from predevelopment conditions to November 1982. The transient model is the primary tool used to describe the Coastal Plain flow system in this report.

The U.S. Geological Survey's three-dimensional, finite-difference modular flow model (McDonald and Harbaugh, 1984) was used for the simulations. The strongly implicit numerical procedure was used to solve the set of simultaneous equations resulting from the finite-difference approximation. Detailed information on the model and solution technique can be found in the report cited above and in Trescott (1975) and Trescott and others (1976).

The South Carolina Coastal Plain flow system was simulated by using a quasi-three-dimensional approach. It was assumed in the model design that flow within aquifers was horizontal. Because horizontal flow in confining layers is negligible compared with that in aquifers, flow within confining units was assumed to be vertical. It was also assumed that the aquifers and confining units are heterogeneous and isotropic. The six aquifer units previously defined and shown schematically in figure 35 were each assigned a model layer and numbered 1 to 5 from land surface down (fig. 36), except the Tertiary sand aquifer and the Floridan aquifer system, which were both assigned to layer 2. Vertical movement of water across confining units was represented in the model as leakage between model layers. It was assumed that there was no change in the amount of water in storage in the confining units.

The Coastal Plain of South Carolina and adjacent areas of Georgia and North Carolina were divided into grid blocks $4 \mathrm{mi}$ on a side, as shown in figure $37 \mathrm{~A}$ through $F$. This discretization yielded a three-dimensional network of 5 layers, 48 rows, and 63 columns. The orientation of the grid was such that it directly corresponded to the grid used for the regional RASA studies of the Southeastern Coastal Plain (Barker and Pernik, 1994) and Floridan aquifer systems (Bush and Johnston, 1988).

The model of the South Carolina Coastal Plain aquifer system only simulates the deeper parts of the flow system as previously described. This includes the deep flow system throughout all of the lower Coastal Plain, but only the part of the flow system in the upper Coastal Plain that directly flows to the large rivers (Savannah, North Fork and South Fork Edisto, Congaree, Wateree, Lynches, Pee Dee, and Lumber Rivers) or that flows downgradient to the lower Coastal Plain. Simulation of the shallow flow system involving local flow to small streams in the upper Coastal Plain was not done because of the coarse model grid necessitated by the scale of this investigation.

\section{MODEL INPUTS}

Input data included transmissivity distribution for each aquifer, leakance coefficients (vertical hydraulic conductivity divided by thickness) for each confining unit, recharge, river-stage altitudes, and streambed conductance values. The transient simulation also required storage coefficient distribution and the groundwater pumping history for the study area for each aquifer. All parameters were fully specified throughout the areal extent of each hydrogeologic unit.

Initial transient model inputs were largely derived from the calibrated predevelopment model (Aucott, 1988). Parameter values used in starting the predevelopment model were derived in a number of ways. Transmissivity values were estimated for each aquifer by using data from aquifer tests and specific-capacity tests (Aucott and Newcome, 1986).

Initial leakance values were derived from published data on hydraulic conductivities of clays (Freeze and Cherry, 1979, p. 24) and approximations of confining unit thicknesses. Values were initially set to be uniform for each confining unit throughout its area of active simulation. The first approximation of recharge distribution was initially estimated by projecting base flow rates throughout the outcrop areas using base flow analyses by Stricker (1983). River-stage altitudes for river nodes (fig. $37 F$ ) were obtained from U.S. Geological Survey gaging stations, where they existed, and otherwise estimated from topographic quadrangles with 5- to $20-\mathrm{ft}$ contour intervals. Streambed conductance values were initially selected from published estimates of hydraulic conductivities of silt (Freeze and Cherry, 1979, p. 24).

The transient model was divided into eight pumping periods as follows: 
NW

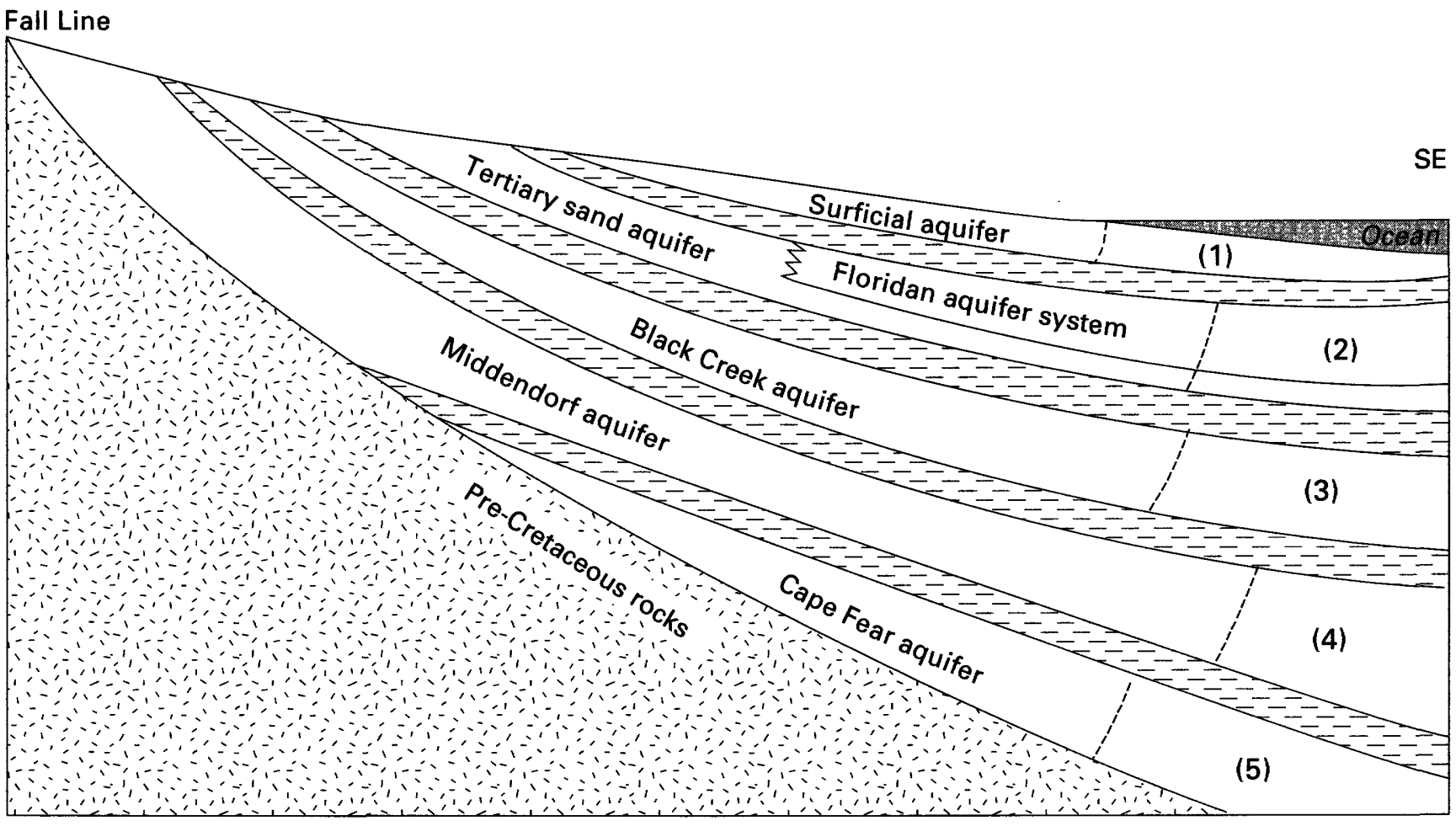

Not to scale

\section{EXPLANATION}

\section{Aquifer}

Confining unit

Approximate freshwater-saltwater interface

(2) Number of layer in the digital model

FIGURE 35. - Diagrammatic geohydrologic section across the South Carolina Coastal Plain.

\begin{tabular}{ccc}
\hline $\begin{array}{c}\text { Pumping } \\
\text { period } \\
\text { number }\end{array}$ & $\begin{array}{c}\text { Time } \\
\text { interval }\end{array}$ & $\begin{array}{c}\text { Length } \\
\text { (years) }\end{array}$ \\
\hline 1 & Predevelopment & - \\
2 & $1935-44$ & 10 \\
3 & $1945-54$ & 10 \\
4 & $1955-64$ & 10 \\
5 & $1965-69$ & 5 \\
6 & $1970-74$ & 5 \\
7 & $1975-79$ & 5 \\
8 & $1980-82$ & 2.8
\end{tabular}

Simulated pumping rates were held constant during each pumping period. Pumping period lengths were selected to be shorter in more recent periods because greater changes occurred in more recent times and because recent data probably are more accurate.

Transient modeling required input data in addition to data necessary for the predevelopment, or steady-state, simulation. A specific yield of 0.15 was used in the half of the aquifer outcrop area nearest its updip limit and was used to simulate unconfined conditions (Stricker, 1983). In all other areas, confined conditions were initially simulated by using a storage coefficient of 0.0003 . The value of the selected storage coefficient for confined aquifers is the median value of 21 published values for South Carolina clastic aquifers (Siple, 1967; Zack, 1977; Park, 1980; Aucott and Newcome, 1986).

Ground-water withdrawals were estimated from published water-use data, telephone surveys, and site visits. In general, more recent data are considered to be the most accurate. Withdrawals were included in the model for users of greater than $0.2 \mathrm{Mgal} / \mathrm{d}$ during 1980 . The spatial distribution of pumpage for 1980 for all users of 2 $\mathrm{Mgal} / \mathrm{d}$ or greater is summarized in figure 20. Withdrawal rates for each stress period for the users of more 


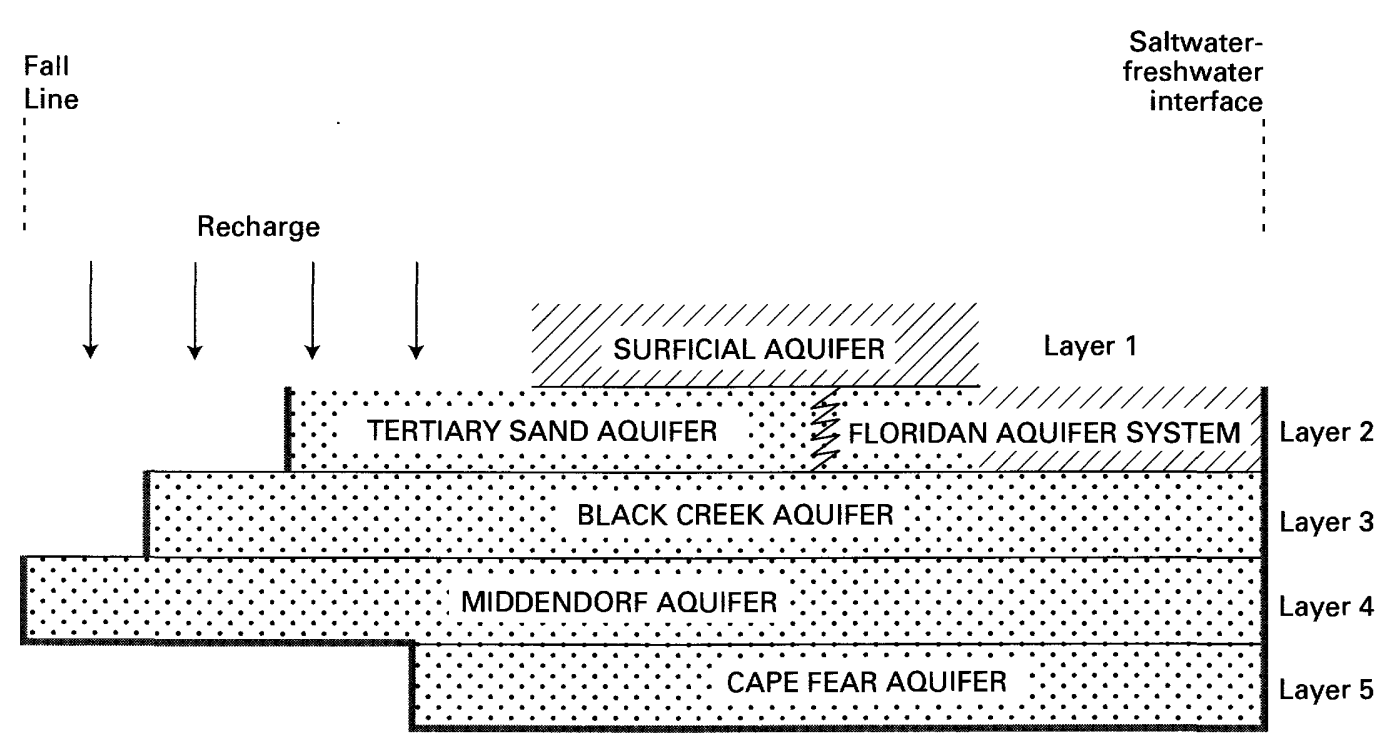

\section{EXPLANATION}

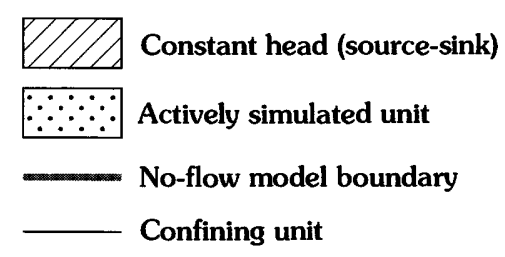

FIGURE 36. - Conceptualization of model layers. Part of the downgradient (saltwater-freshwater) boundary of the Black Creek and Middendorf aquifers was simulated with a general-head boundary in the transient model.

than $2 \mathrm{Mgal} / \mathrm{d}$ during $1980-82$ are listed in table 3. Irrigation use prior to 1980 was relatively minor. Most municipal water use shows a gradual increase over time. Some industrial water-use patterns show abrupt changes indicative of plant openings or closings.

The effects of large withdrawals in shallow zones, which are frequently associated with the dewatering of quarries, generally were not simulated because the surficial aquifer in the eastern part of the study area and the Floridan aquifer system in the western part of the study area were simulated as constant-head source-sink layers. Thus, water levels in these layers could not vary. An attempt was made to simulate the effects of large withdrawals from shallow zones in actively modeled layers in the upper Coastal Plain. However, these effects generally could not be accurately modeled because the scale of the model does not allow the shallow flow system to be simulated. Withdrawals from the part of the Floridan aquifer system simulated by Bush and Johnston (1988) and by Krause and Randolph (1989), particularly in the Savannah area, were not modeled under transient conditions because, in this area, the Floridan was simulated as a constant-head source-sink layer.

\section{MODEL BOUNDARIES}

The model boundaries used for the transient simulations described in this report are depicted in figures 36 and 37. Three types of boundaries were used. The first type, a no-flow boundary, allows the hydraulic head to vary but prevents the movement of water across the boundary. The second type, a constant-head boundary, fixes the hydraulic head at a specified value but allows the movement of water across the boundary. The third type, a general-head boundary, allows the hydraulic head to vary from its specified value and allows the movement of water across the boundary to vary as well according to a hydraulic conductance term (McDonald and Harbaugh, 1984, p. 343). Boundaries for the transient model were identical to those used for the predevelopment model (Aucott, 1988) with the exception that general-head boundaries were substituted for constanthead and no-flow boundaries in parts of the Black Creek aquifer and Middendorf aquifer (see fig. $37 C$ and $D$ ) and adjustments were made in source-sink heads, as described later.

The boundaries chosen simulate observed conditions everywhere as closely as possible. In general, a no-flow 
boundary is used where little or no water flows across a particular boundary. A constant-head boundary is used where water flows across the boundary but the head is known and has remained constant through the interval of time of the simulation. A general-head boundary is used to simulate boundaries that are changing with time, such as those affected by pumping. Areas inside the model boundaries are actively simulated, and heads and flows are computed in all active cells. In inactive areas (constant-head or no-flow cells), either heads or flows, or both, are not computed but, rather, are specified.

Overlying the clastic aquifers are the surficial aquifer in the east and the part of the Floridan aquifer system previously modeled by Krause (1982), Bush and Johnston (1988), and Krause and Randolph (1989) in the southwest. The surficial aquifer was simulated with constant heads and acts as a source or sink layer in the eastern part of the model (fig. 37A). A source-sink layer enables the simulation of flow vertically into or out of the actively simulated area. Surficial aquifer heads were taken from the predevelopment model. They were originally estimated by subtracting the estimated depth to water from land-surface elevations as determined from topographic maps. The previously modeled part of the Floridan aquifer system in South Carolina and Georgia (Bush and Johnston, 1988) within this study area was also simulated with constant heads and similarly acts as a source-sink layer in the west. Heads for the part of the Floridan aquifer system modeled by Krause (1982), Bush and Johnston (1988), and Krause and Randolph (1989) were derived by using simulated heads from Krause (1982) as modified by more recent field data in Georgia (R.E. Faye, U.S. Geological Survey, written commun., 1984). Predevelopment heads were used for the predevelopment simulation. In the area where constant heads were assigned to the Floridan aquifer system (fig. 37B), 1982 measured heads were used and held constant throughout the transient simulation. This solution was deemed to be adequate because the effects of the inaccuracy of these heads on the underlying Black Creek and Middendorf aquifers appeared to be small when comparing head changes in the transient simulation to the predevelopment simulation, which used predevelopment Floridan heads. This seems reasonable because the permeable Cretaceous sediments are separated from the Floridan aquifer system by about $1,500 \mathrm{ft}$ of predominantly clayey sediments in the Savannah, Ga., area, where the head declines in the Floridan have been large. These sourcesink layers act as the upper boundary of the model. The remainder of the Floridan aquifer system and its updip equivalent, the Tertiary sand aquifer, were simulated actively (figs. 36 and $37 B$ ).
Underlying the sediments that compose the Coastal Plain aquifer system are pre-Cretaceous igneous, metamorphic, and consolidated sedimentary rocks, all of low permeability. The flow of water within these preCretaceous rocks and between them and the overlying Coastal Plain aquifers is considerably less than flow within the Coastal Plain aquifers. The interface between Coastal Plain sediments and the underlying preCretaceous rocks can thus be reasonably simulated as a no-flow boundary.

The updip limit of each aquifer represents the pinchout of the wedge of sediments composing that particular aquifer. Where the aquifer does not exist, no flow occurs in a given model layer across such a boundary (figs. 35-37). The updip limit of all aquifers is thus simulated with a no-flow boundary.

The downdip limit of all model layers is the saltwaterfreshwater interface. Only the freshwater flow system is simulated by the model. Although the saltwaterfreshwater interface in nature is gradational, it is considered in this report to represent a sharp boundary as defined by a line representing a concentration of 10,000 $\mathrm{mg} / \mathrm{L}$ of dissolved solids in the water within a given aquifer. Because steady-state conditions were approximated in the flow system prior to development, the saltwater-freshwater interface was considered to be stationary for the predevelopment model. It can be assumed that there is no flow across the interface, although some circulation does exist between the freshwater and saltwater flow systems (Glover, 1964; G. Bennett, U.S. Geological Survey, written commun., 1979). The interface was simulated as a no-flow boundary in all active layers in the predevelopment model. The position of this interface, which exists nearly everywhere beneath the Atlantic Ocean, cannot be accurately determined by using existing data. Its approximate position was estimated by using data on its position in Georgia and North Carolina (Lee and others, 1985). Early calibration runs of the transient model indicated that the effects of pumping stress in the Myrtle Beach area extended to the saltwater-freshwater interface and lateral boundary. As a result, the no-flow boundary in the predevelopment model was replaced by a general-head boundary in the Myrtle Beach area in the transient model (fig. 37). This boundary, which permits flow across it in response to changes in head, was used for parts of the interface that could possibly be affected in the transient simulation and provides water to the model to account for movement of the interface.

Unlike the boundaries previously discussed, the lateral boundaries to the northeast and the southwest do not necessarily represent definite hydrologic boundaries. Although ground-water divides or rivers may provide reasonable boundary conditions for one or two aquifers in 

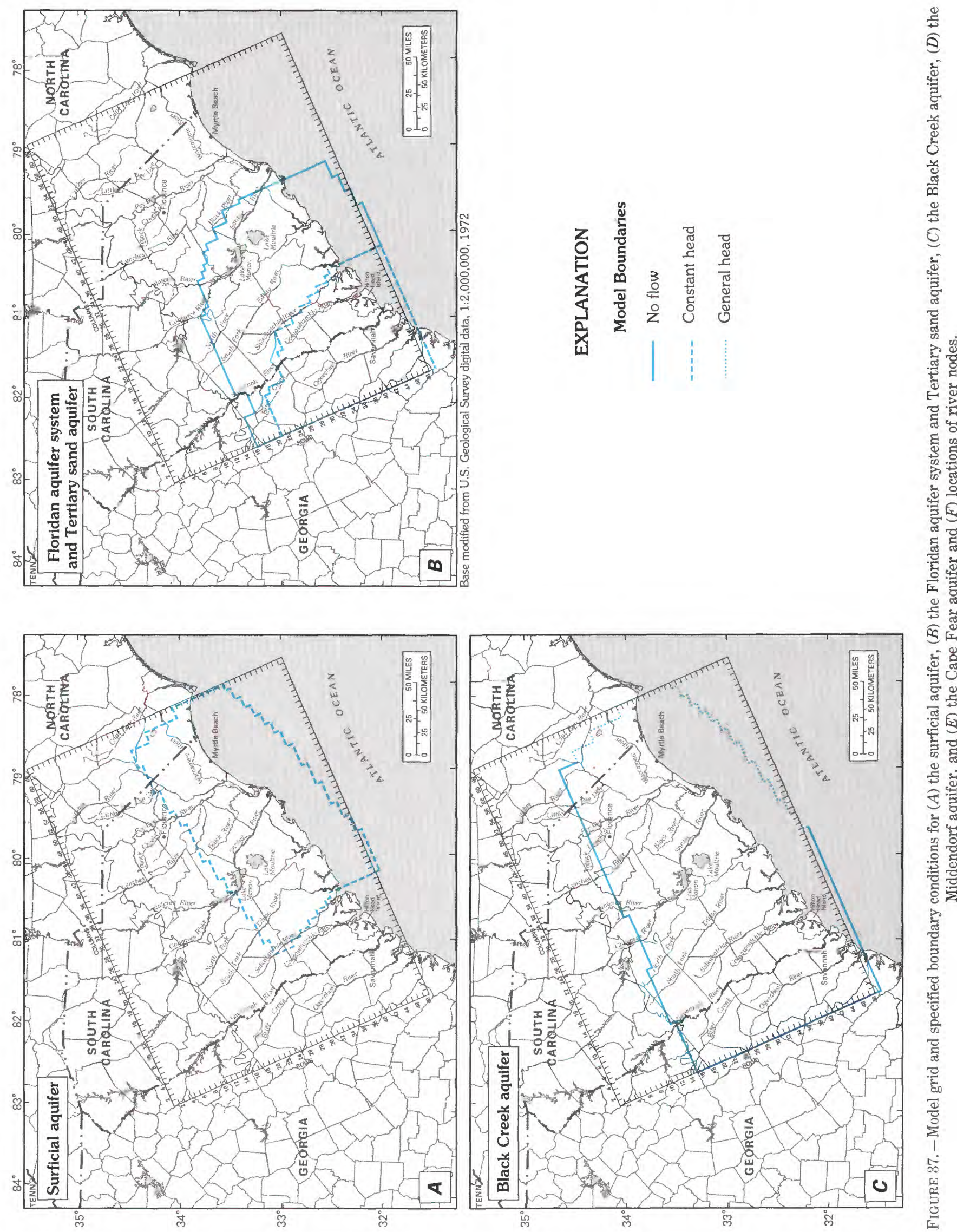

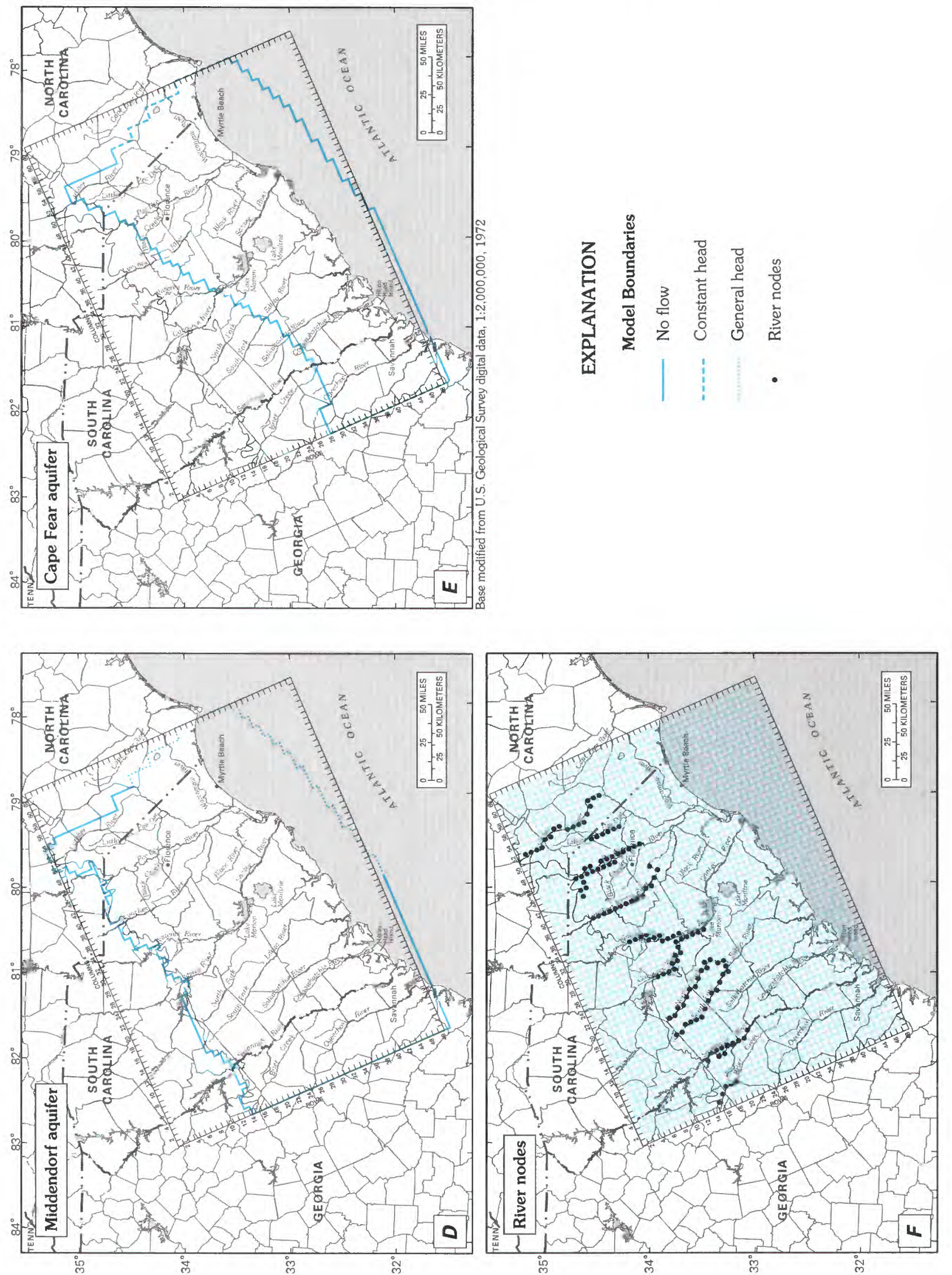

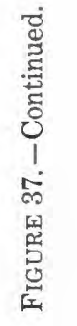


TABLE 3.-Ground-water withdrawals by major users, 1935-82'

$[-$, no reported water use $]$

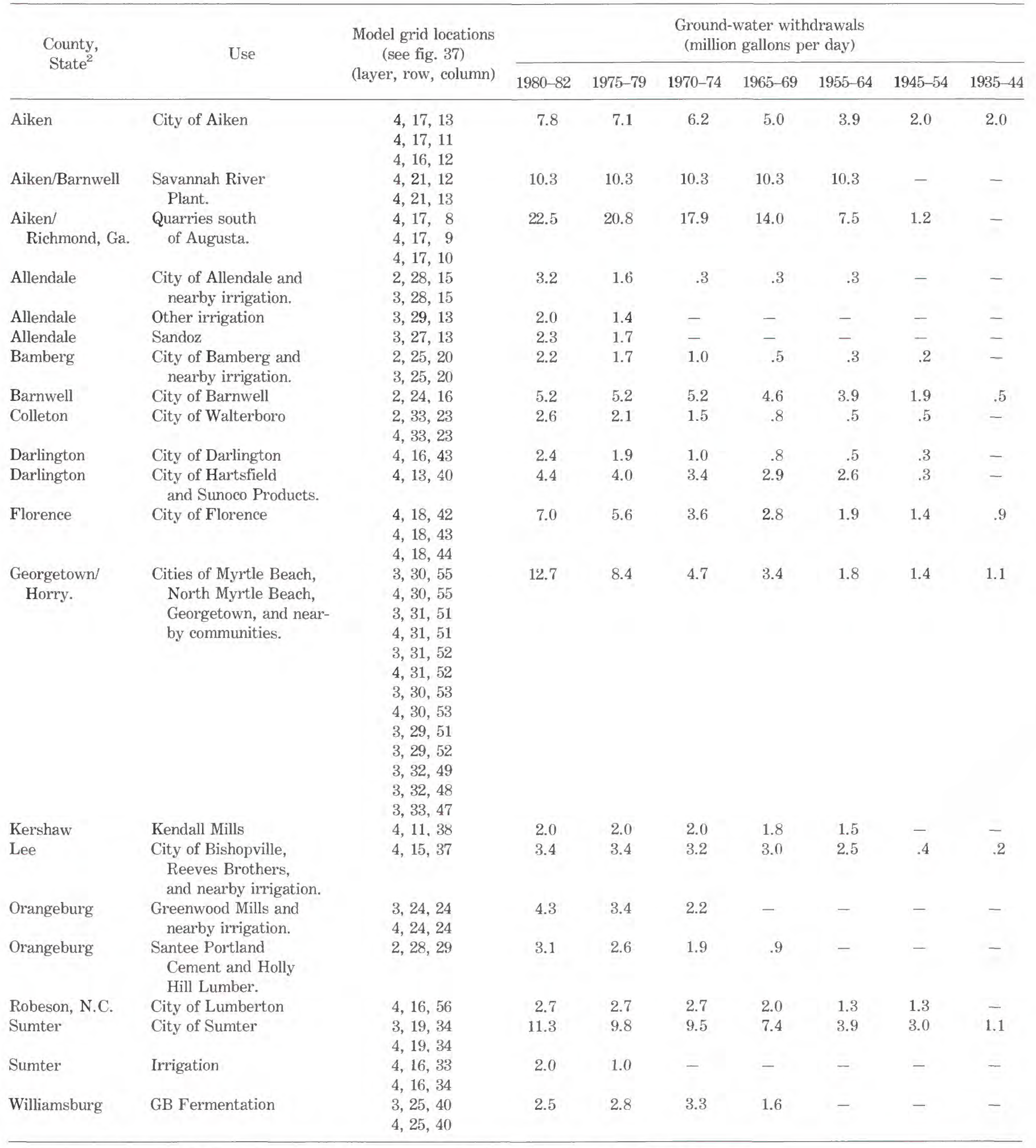

${ }^{1}$ Withdrawals of less than 2 million gallons per day were not simulated in the model and are not included in this table.

${ }^{2}$ South Carolina unless otherwise indicated. 
limited areas, lateral hydrologic boundaries of regional extent generally are not present within the Coastal Plain. The southwestern boundary for all aquifers was selected as constant heads far enough to the southwest in Georgia so that the boundary did not appreciably influence simulation results within the Coastal Plain of South Carolina, which is the primary area of interest of this study.

The northeastern boundaries are more complex. The boundary of the Middendorf aquifer in the upper Coastal Plain was simulated as no flow because it was located along a ground-water divide. The northeastern boundaries of the Black Creek, Middendorf, and Cape Fear aquifers in the lower Coastal Plain were simulated as constant head in the predevelopment model. In the lower Coastal Plain, head declines have reached the northeastern boundaries of the Black Creek and Middendorf aquifers as a result of pumpage near Myrtle Beach and other areas. Therefore, the boundaries of these aquifers were changed to general-head boundaries for the transient simulation to more accurately simulate the changing head and the flow across boundaries (fig. $37 C$ and $D$ ).

\section{MODEL CALIBRATION}

Parameters used to determine the adequacy of model calibration were predevelopment heads, November 1982 heads, selected heads between these times, and groundwater discharge to the larger rivers in the upper Coastal Plain. Calibration parameters were not adjusted during the simulations but were used for comparison between simulated and observed values to determine the adequacy of the model calibration. The calibration parameters for the predevelopment (steady-state) simulation were the predevelopment heads for the aquifers in all actively simulated areas and base flows for selected reaches of upper Coastal Plain rivers (Aucott, 1988). Predevelopment heads were determined from potentiometric-surface maps by Aucott and Speiran (1985c) (figs. 15 through 18 of this report). Base flows used were determined from low-flow calculations by Aucott, Meadows, and Patterson (1987). Calibration parameters for transient simulation were declines in head from predevelopment to November 1982 (figs. 24 through 26), as shown in Aucott and Speiran (1985b), and changes in water levels over time for selected wells near areas of large pumping stress.

Calibration of the predevelopment model was accomplished by trial-and-error adjustment of model inputs except for river altitudes. After each adjustment, simulated heads and streamflows were compared with those derived from field measurements to evaluate the progress attained in that adjustment. After many trial- and-error adjustments, a satisfactory calibration was achieved (Aucott, 1988).

Parameters most adjusted were recharge, leakance coefficients of confining units, aquifer transmissivity (mostly near the updip limit of each aquifer), and streambed conductance. These parameters were adjusted most because initial estimates were relatively poor due to sparse data and because the simulation was sensitive to adjustments of these parameters. Initial estimates of other parameters, such as aquifer transmissivity (away from the updip limit), were relatively good and thus had a much smaller range of reasonable adjustments possible.

After the predevelopment model was calibrated (Aucott, 1988), it was reconstructed to simulate transient conditions from predevelopment to November 1982. The transient model was then calibrated by using a trial-anderror adjustment technique similar to that used for the steady-state simulation. Transient calibration required some adjustments to parameters used in the steady-state simulation; however, the necessary adjustments were small relative to changes made during the original steady-state calibration. The parameters adjusted were transmissivity, leakance coefficient, and storage coefficient values.

Calibration criteria used for the transient simulation varied somewhat from those used for the steady-state simulation. Two factors were used in assessing the adequacy of the transient calibration. The first criterion was to match simulated drawdowns (simulated predevelopment heads minus simulated November 1982 heads) with drawdowns determined from field data as mapped by Aucott and Speiran (1985b). This comparison yielded a mean absolute head difference of $11.2 \mathrm{ft}$, which was considered reasonable, given the predevelopment calibration and the uncertainties in input data such as withdrawals. Because the surficial aquifer was simulated as a constant-head source-sink layer, and because field data were insufficient to construct a drawdown map for the Cape Fear aquifer, comparison of drawdown maps was only possible for the actively simulated part of the Floridan aquifer system-Tertiary sand aquifer (fig. 38), the Black Creek aquifer (fig. 39), and the Middendorf aquifer (fig. 40).

As a check during calibration of the transient model, data sets were input into the predevelopment (steadystate) model. When the final data sets of the transient model were input into the predevelopment model, the mean absolute head difference was $10.3 \mathrm{ft}$, whereas the difference obtained by using the predevelopment data set was $8.9 \mathrm{ft}$. Although this difference was greater than desired, results are still considered reasonable. The transient model data sets are considered to be more 


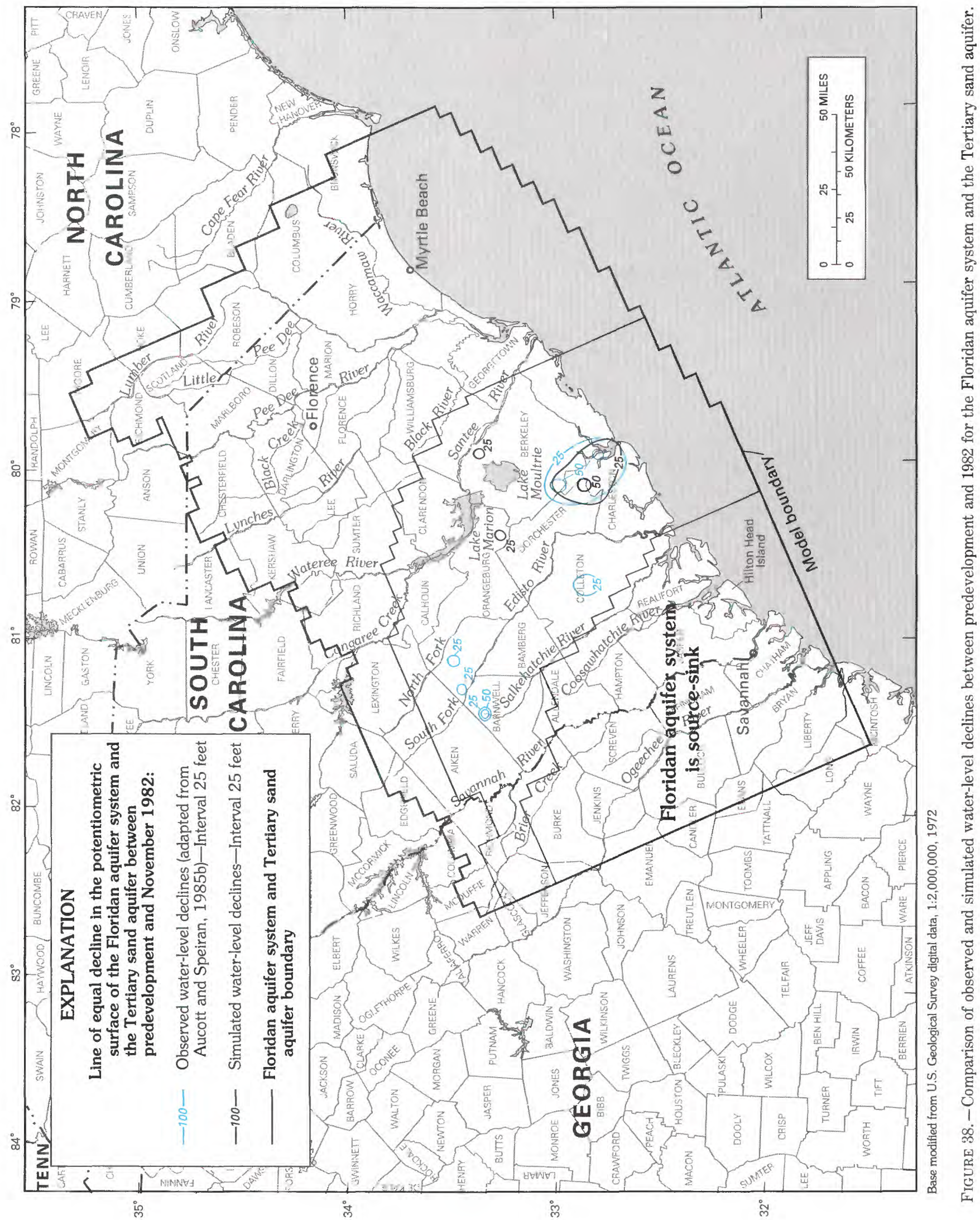




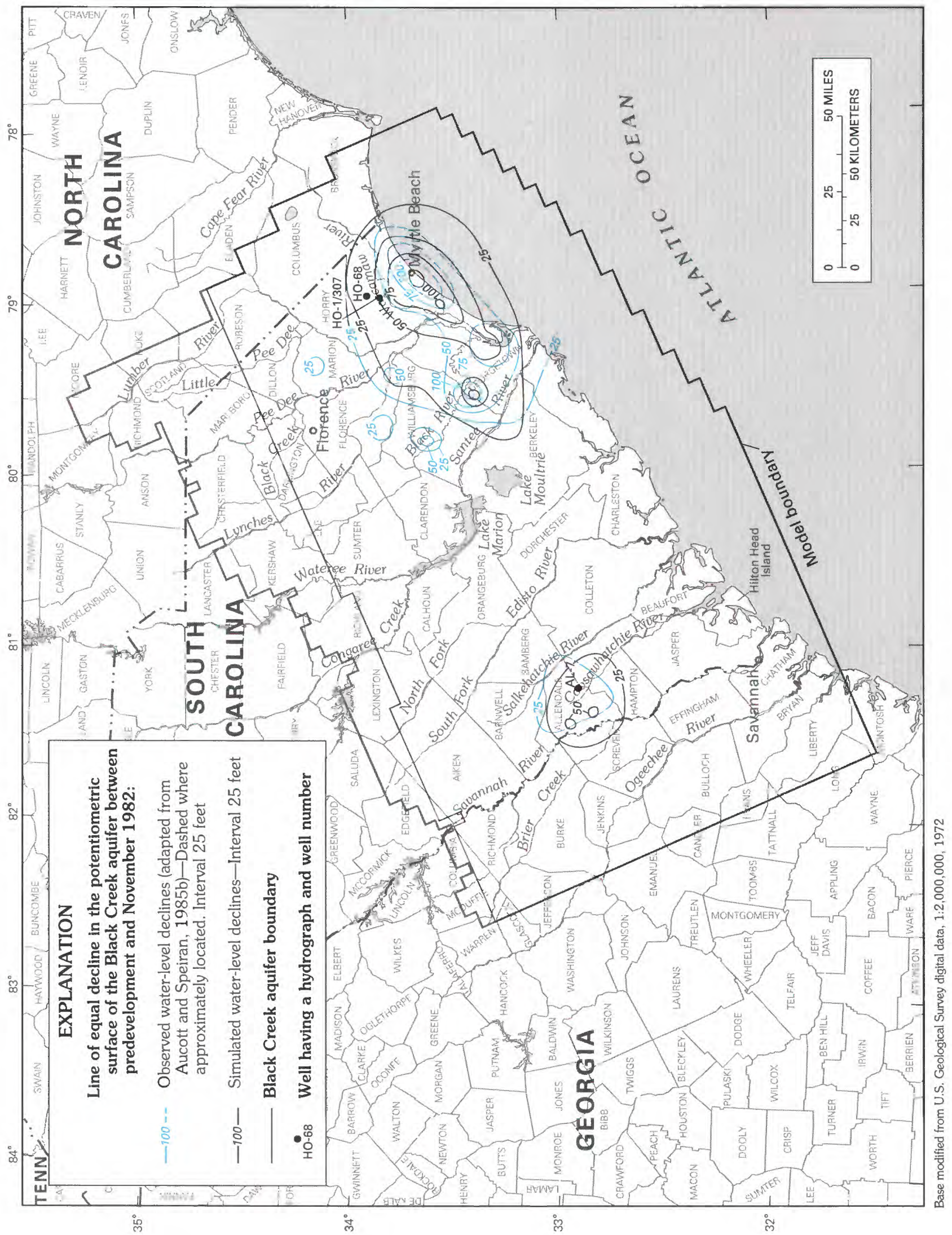

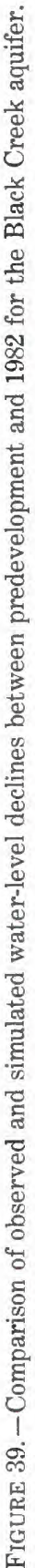




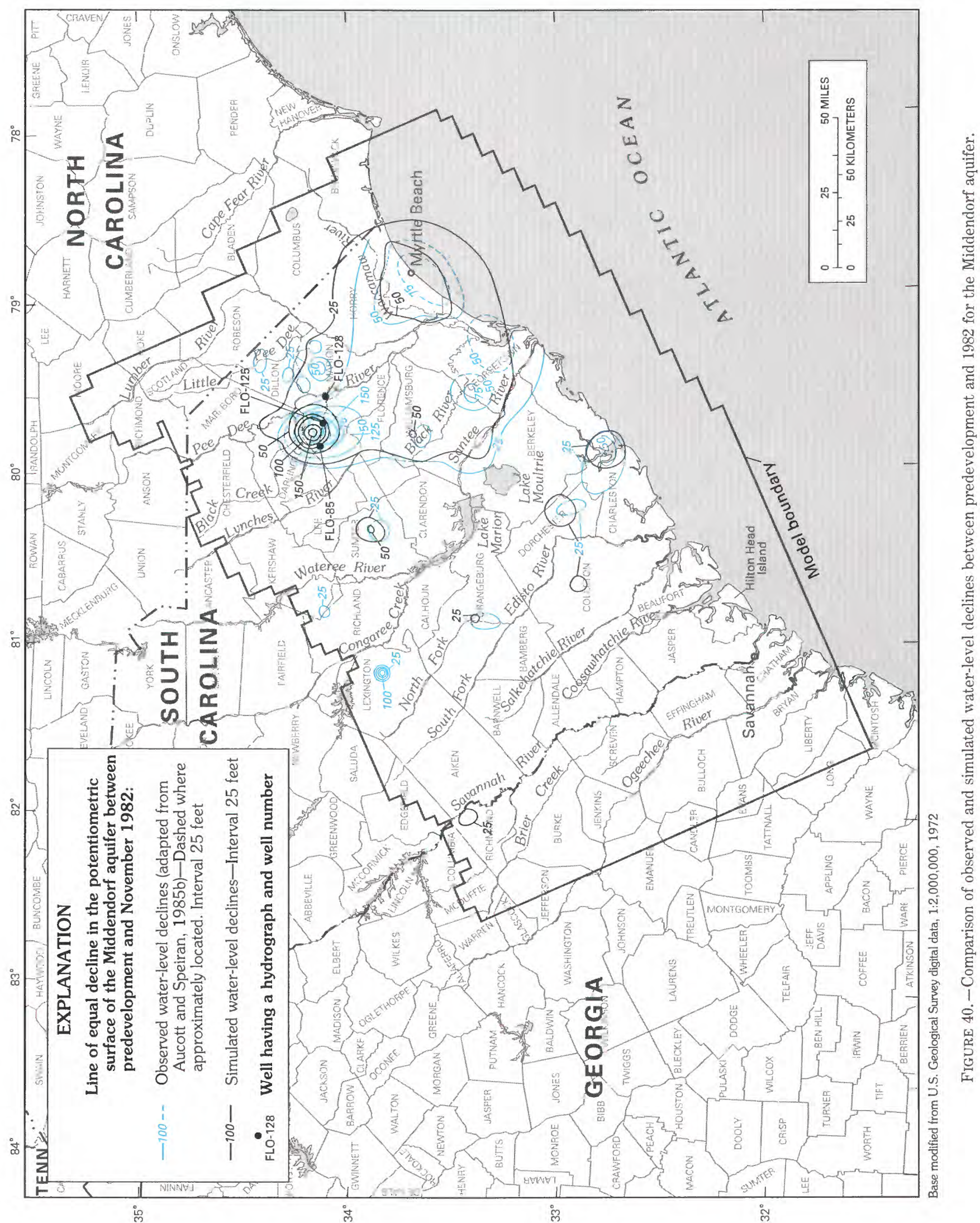


reliable because the calibration criteria and model stress provided a more rigorous model calibration.

The only major areal head decline in the actively modeled area in the Floridan aquifer system and Tertiary sand aquifer is located in the CharlestonSummerville area and is matched well by the simulation (fig. 38). Declines resulting from other, much smaller pumping centers in these aquifers did not match as well. Reasons for the poorer matches are the effects of the shallow flow system, which was not simulated, limited field data, and the small area affected by these declines compared with the coarse model grid size. No special calibration efforts were made to attain a better match because of the limited extent of these declines.

The major areal decline in heads in the Black Creek aquifer is located in the Myrtle Beach-Georgetown area and is simulated well by the model (fig. 39). The minor differences in extent and shape of the simulated and observed declines are probably a result, at least in part, of inaccuracies in location and distribution of pumpage or possibly insufficient head data. Simulation of an area of smaller head declines in Allendale County is reasonable.

Declines simulated for the Middendorf aquifer (fig. 40) generally matched well with observed declines. At the principal pumping center in Florence, the extent of the simulated and observed declines matches well. Differences in simulated versus observed water-level declines in Dillon and northern Marion Counties are regionally insignificant and could result from sparse water-level measurements there.

Simulated and observed head declines in the Middendorf aquifer matched reasonably well in other parts of the area of regional decline in eastern South Carolina. Little calibration adjustment was made here because the potentiometric surface of the Middendorf aquifer (Aucott and Speiran, 1985b, fig. 10) in the eastern part of the lower Coastal Plain was mostly inferred from the Black Creek aquifer decline map. Only a few head measurements in wells tapping the Middendorf aquifer were available. The large differences in western Georgetown County probably result from an inference of much greater leakage in the construction of the observed head decline maps than actually occurs.

The correspondence between observed and simulated head declines generally was good for other parts of the Middendorf aquifer. Simulated effects of large withdrawals in Sumter and Aiken-Barnwell Counties (Savannah River Plant) were minimal and corresponded reasonably well to field observations. Some decline has occurred at the Savannah River Plant, but it has been less than $25 \mathrm{ft}$. Head declines in the Charleston-Dorchester County area also were simulated quite well. Simulated declines overestimated observed declines by about $10 \mathrm{ft}$ in the vicinity of the Colleton County pumping center and also departed somewhat from observed declines in the northern part of the Charleston-Dorchester County cone.

No comparisons of head declines were made in Georgia and North Carolina because affected areas in those States are small, close to the lateral boundaries of the model, and not in the principal area of interest. Similarly, no comparisons were made near the Fall Line because of the problems of simulating the effects of withdrawals there resulting from scale and the model only simulating the deep flow system.

The other calibration criterion used was a comparison of observed and simulated rates of head decline in areas of large withdrawals. Unfortunately, adequate field data were available for the construction of only a few longterm hydrographs. Six hydrographs (figs. 41 and 42) were used to compare rates of head decline. The available hydrographs are from wells located mostly near the large centers of decline resulting from pumping at Florence and Myrtle Beach. The locations of these wells, which are screened in the Black Creek and Middendorf aquifers, are shown in figures 39 and 40 . Other major pumping centers (Sumter and the Savannah River Plant) appear to have relatively isolated, shallow cones of depression. Insufficient head declines have occurred in these or other areas for useful comparison of simulated and observed rates of decline.

Hydrographs in figure 41 are from wells completed in the Middendorf aquifer in the vicinity of Florence. Figure $41 B$ is representative of wells located near the center of pumping, whereas figures $41 \mathrm{~A}$ and $41 \mathrm{C}$ are representative of wells located some distance away from the center of pumping. The matches of observed and simulated trends are fairly good, although the shapes of the observed and simulated hydrographs differ somewhat. The rate of simulated head decline during the last two stress periods is somewhat greater than observed declines shown in figure $41 B$. This probably reflects the difficulty in accurately comparing observed and simulated drawdowns in model nodes with many large ground-water withdrawals. Many factors could be involved, including (1) the model computing heads at the center of the node when pumping and observation wells are not at the node center and (2) sources of water not included in the simulation, such as water derived from the inelastic compression of clays. The correlation between simulated and observed data is better in a node adjacent to one with large withdrawals (fig. 41A). Water levels in well FLO-85 (Union Carbide well) are lower than simulated water levels because the observation well is closer to the adjacent pumping node than it is to its node center. Differences between simulated and observed heads shown in figure $41 C$ probably relate to the fact that the Middendorf aquifer is much more 
MODEL STRESS PERIOD
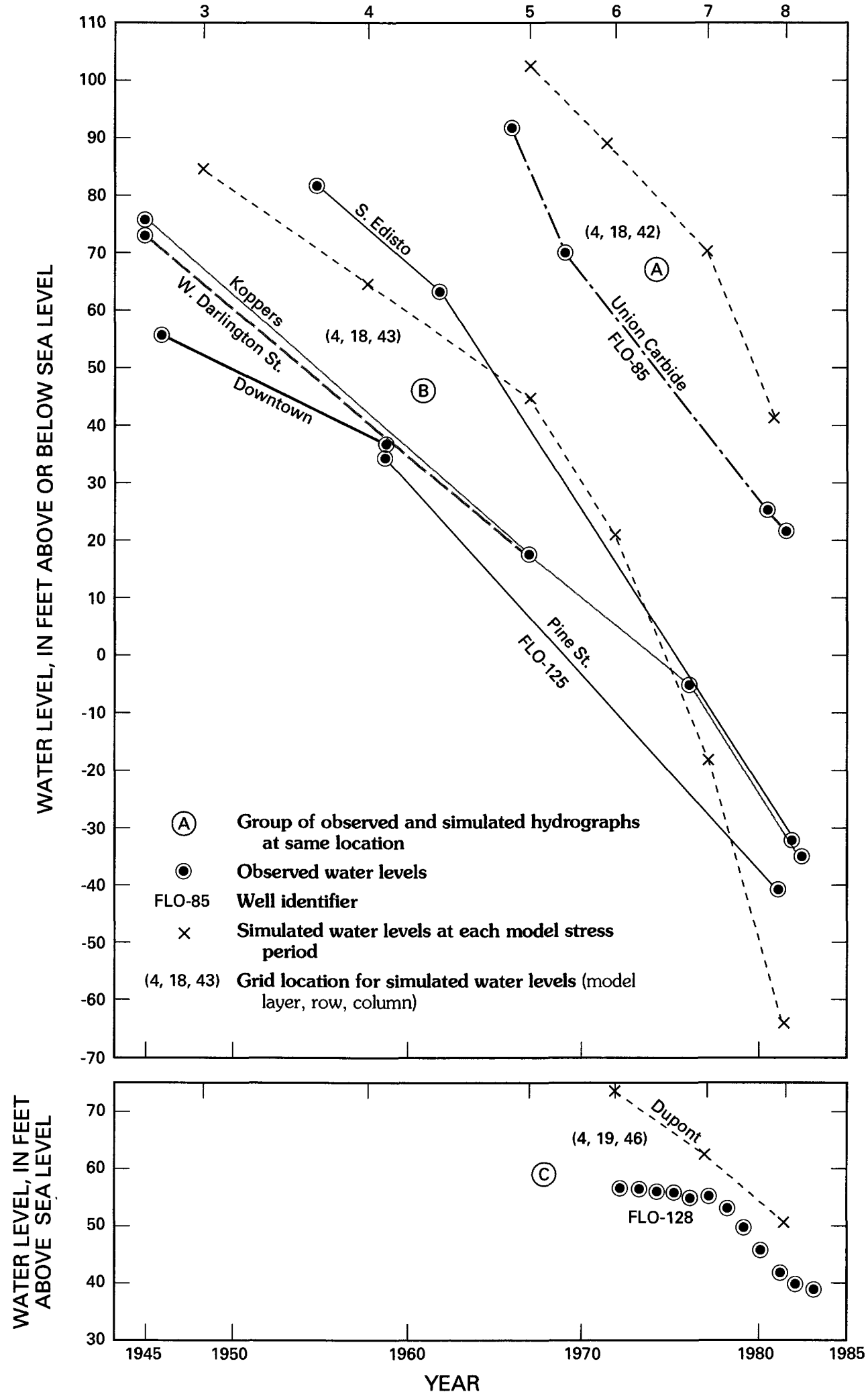

FIGURE 41. - Hydrographs of observed and simulated water levels near Florence, S.C. 

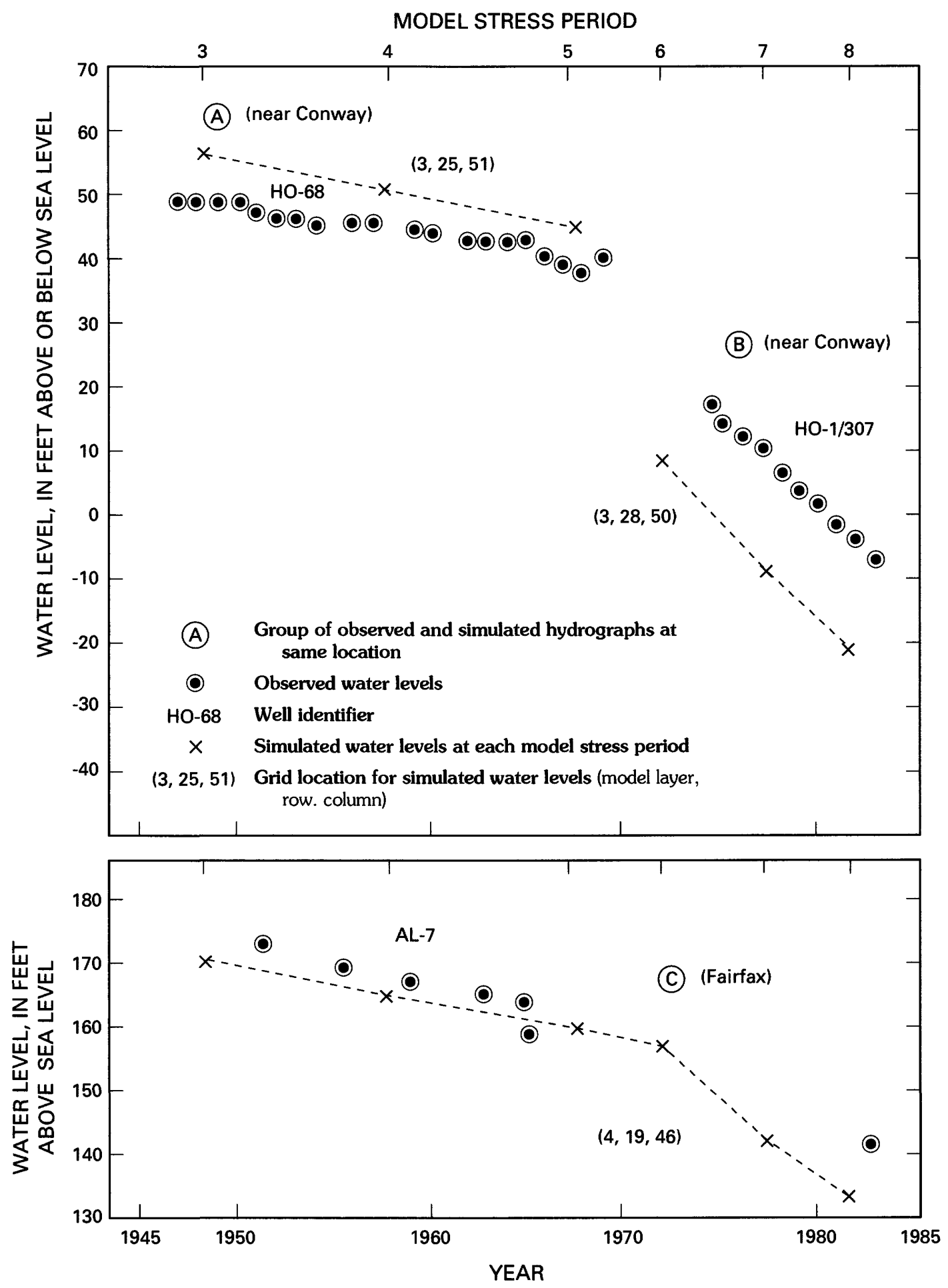

FiguRE 42. - Hydrographs of observed and simulated water levels near Conway and Fairfax, S.C.

heterogeneous and contains more clayey material near and to the east of the Pee Dee River than to the west.

Hydrographs in figure $42 A$ and $B$ are from two wells in Horry County that are screened in the Black Creek aquifer and show the effects of pumping in the Myrtle Beach area. The slopes of the simulated and observed hydrographs are similar for both wells. Other head measurements in this area generally are limited to 
measurements made since 1974 and are from observation wells located near pumping wells.

The hydrograph in figure $42 C$ represents a well in Allendale County that monitors head declines in the Black Creek aquifer. The shapes of the simulated and observed hydrographs compare favorably for the early part of the hydrograph (stress periods 3-5). The 1982 measurement differs by about $10 \mathrm{ft}$ from the simulated water level. This may be a result of heterogeneities in the Black Creek aquifer, such as sand-clay layering, which would cause vertical variations of head within the aquifer in this area, inaccuracies in the pumping history, or a greater aquifer storage coefficient than simulated.

All six hydrographs in figures 41 and 42 indicate that the general trends of simulated head declines in the major areas affected by pumpage are similar to observed trends. However, simulated and observed water levels may show considerable differences.

\section{SENSITIVITY TESTING}

Testing was performed to determine the sensitivity of the predevelopment and transient models to changes in various input parameters. Tested parameters included recharge, transmissivity, leakance coefficient, and riverbed conductance for the predevelopment and transient simulations, and storage coefficient and pumping rates for the transient simulation. Given the complexity of the models and the large number of parameters, layers, and nodes, complete testing of all the possible combinations was not practical. The procedure used to test sensitivity was to vary one parameter by a given multiple for every node in every layer of the model and observe the effects on simulated heads and total riverflow. The sensitivity of the calibrated predevelopment and transient model solutions to changes in each input parameter is shown in figures 43 (impact of changes on heads) and 44 (impact of changes on simulated riverflow). Sensitivity was determined using head residuals (fig. 43), which are the differences between simulated heads and heads from contoured field data in every model cell. Predevelopment heads were compared for the steady-state model, whereas 1982 heads were compared for the transient model.

Because the sensitivity testing was of a general nature, the resulting conclusions must be general as well. Overall, head residuals in both models appear to be most sensitive to changes in aquifer transmissivity and increases in recharge. Changes in the leakance coefficient of confining units have a great effect on both models. The transient model was moderately sensitive to changes in pumping rates and less sensitive to changes in storage coefficient. In nearly all cases, the transient model appeared to be about as sensitive to changes in individual input parameters as the predevelopment model.

The calibration of the Middendorf aquifer layer in both models was extremely sensitive to decreases in transmissivity. The Middendorf aquifer has the largest area of outcrop available to receive direct recharge. Because no underlying aquifer exists in the outcrop area, the Middendorf aquifer is particularly sensitive to changes in transmissivity and recharge there.

Because both the predevelopment and transient models are relatively sensitive to changes in leakance coefficient and recharge, both of which are largely derived by model calibration, the confidence in the calibrations is greater than it would have been if the models were relatively insensitive to these parameters. Model results do not represent a unique solution in the description of the flow system. The results of sensitivity testing, however, give some indication of the limits within which a given parameter may vary and still provide a reasonable solution.

Total riverflow (fig. 44) in both the predevelopment and transient models is most sensitive to changes in recharge, as expected, and is somewhat less sensitive to changes in pumping rates. Total riverflow is least sensitive to changes in storage coefficient and specific yield, and leakance coefficient of confining units. Because most aquifer-to-river discharge occurs where the aquifers are unconfined, the insensitivity of riverflow to leakance coefficient is not surprising. Changes in transmissivity and riverbed conductance result in moderate changes in riverflow. The sensitivity of total riverflow in both the steady-state and transient models to changes in each input parameter is similar.

\section{MODEL-DERIVED HYDROLOGIC CHARACTERISTICS}

The transmissivity distributions from the calibrated transient model shown in figures 45 through 48 are little changed from the values obtained from the transmissivity calibrated for the predevelopment model. The only changes made in transmissivity during calibration of the transient model were reductions in the transmissivity of the Middendorf aquifer. Reductions of about 50 percent were needed to adequately simulate head declines in this aquifer in the Florence area. The resulting Middendorf transmissivities in the Florence area are somewhat low in comparison with existing aquifer-test and specificcapacity information. The Middendorf aquifer in the Florence vicinity is highly stratified and contains numerous clay beds that inhibit uniform head-change distribution, as is the case in a homogeneous aquifer. This raises 


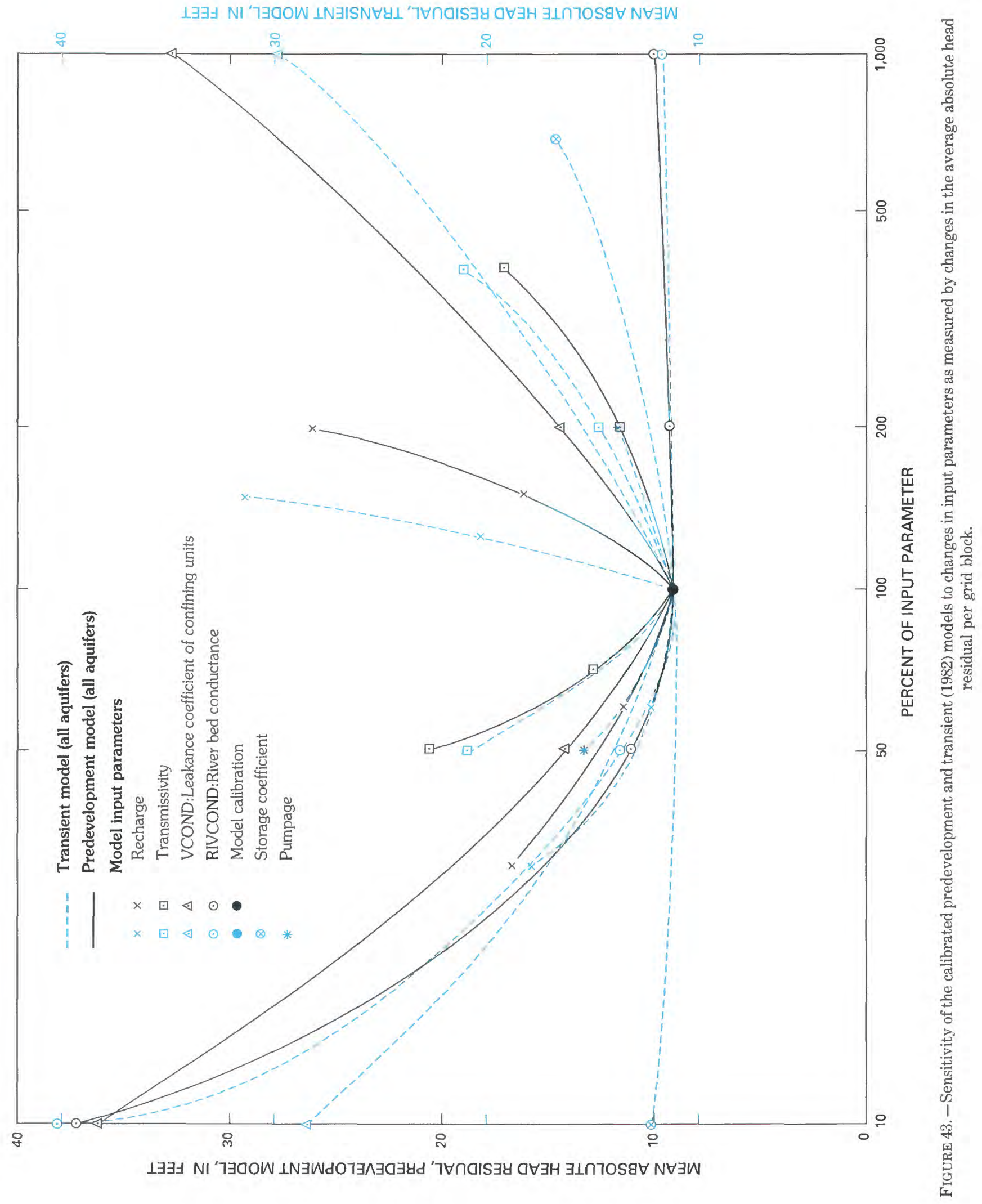




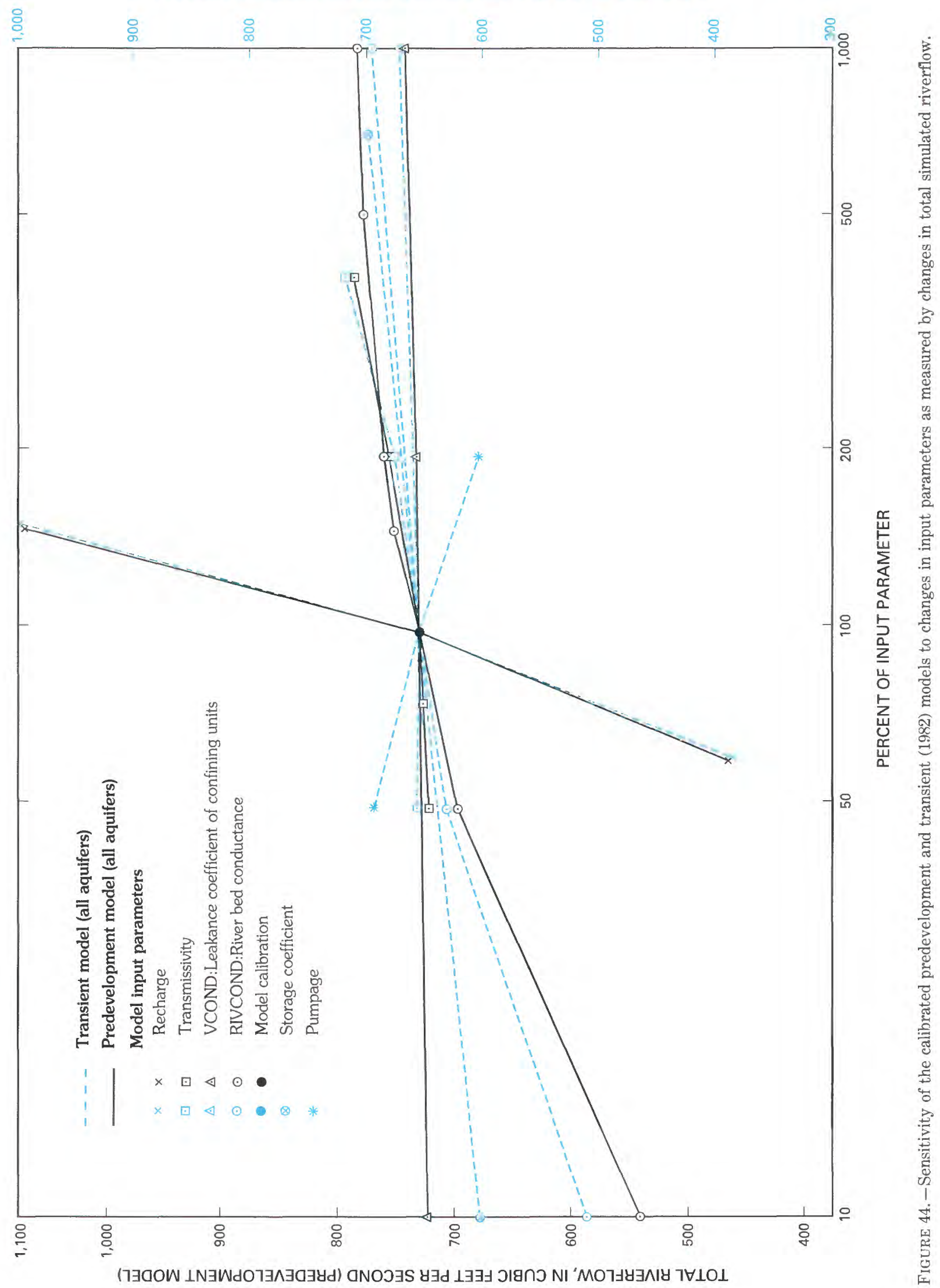




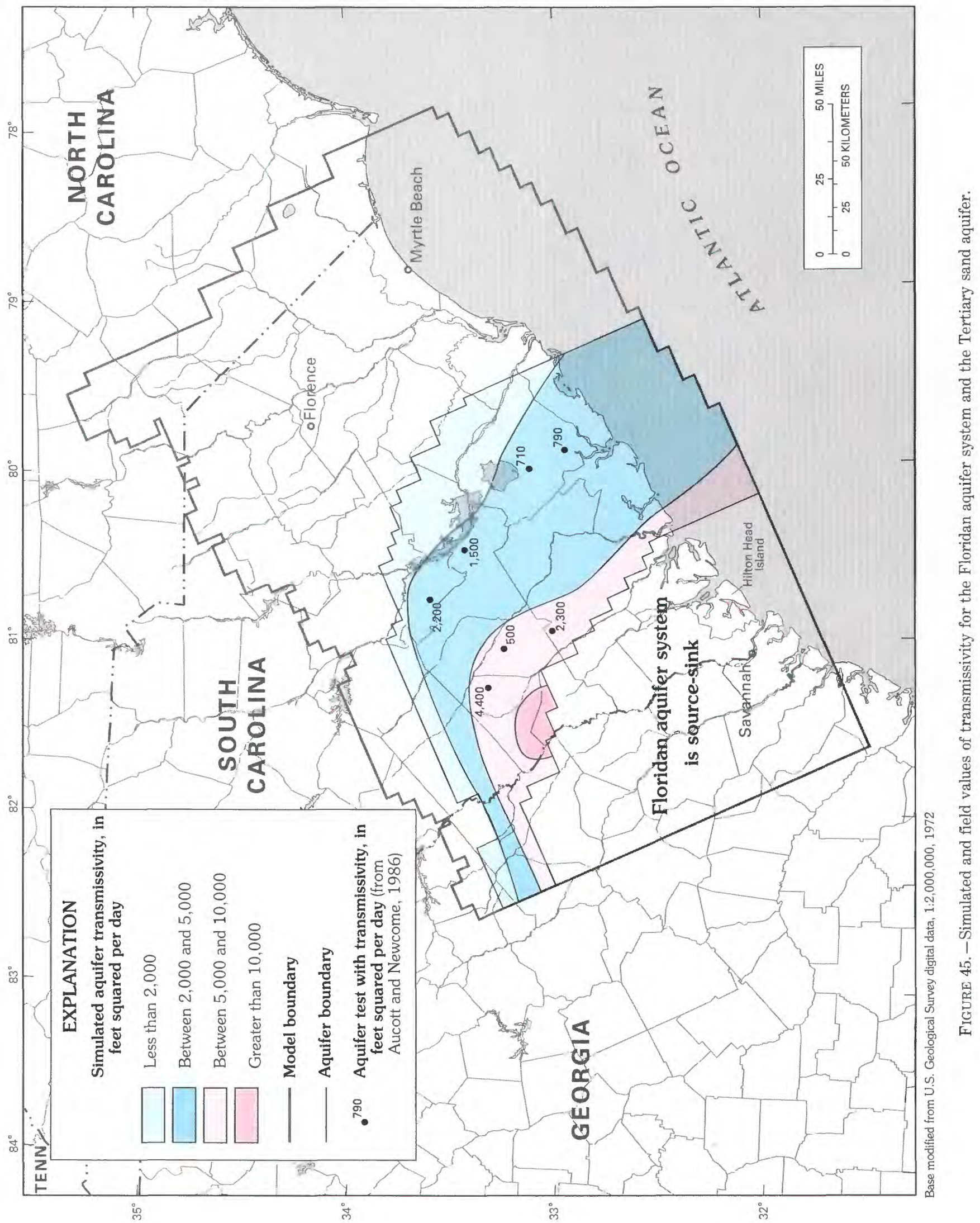




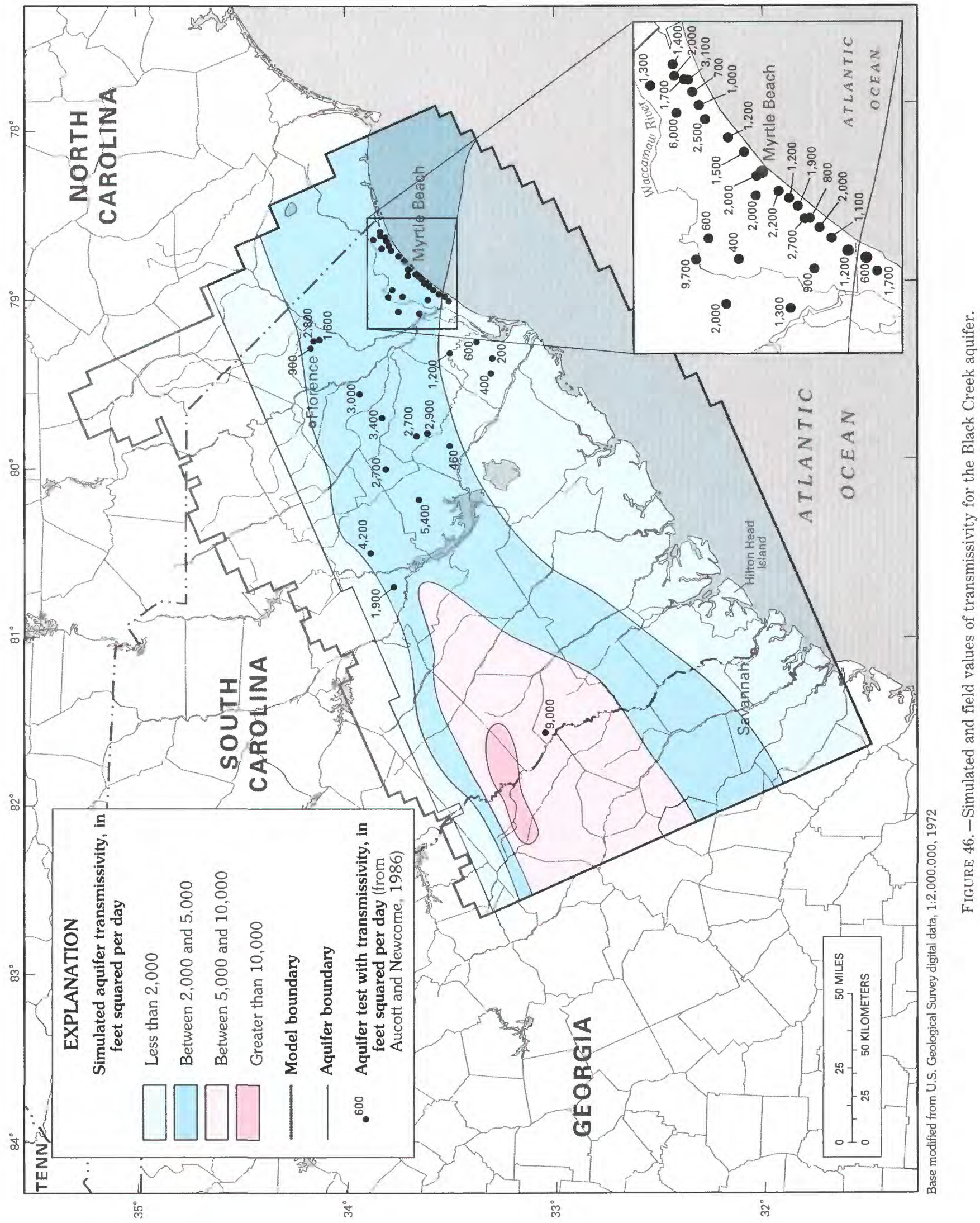




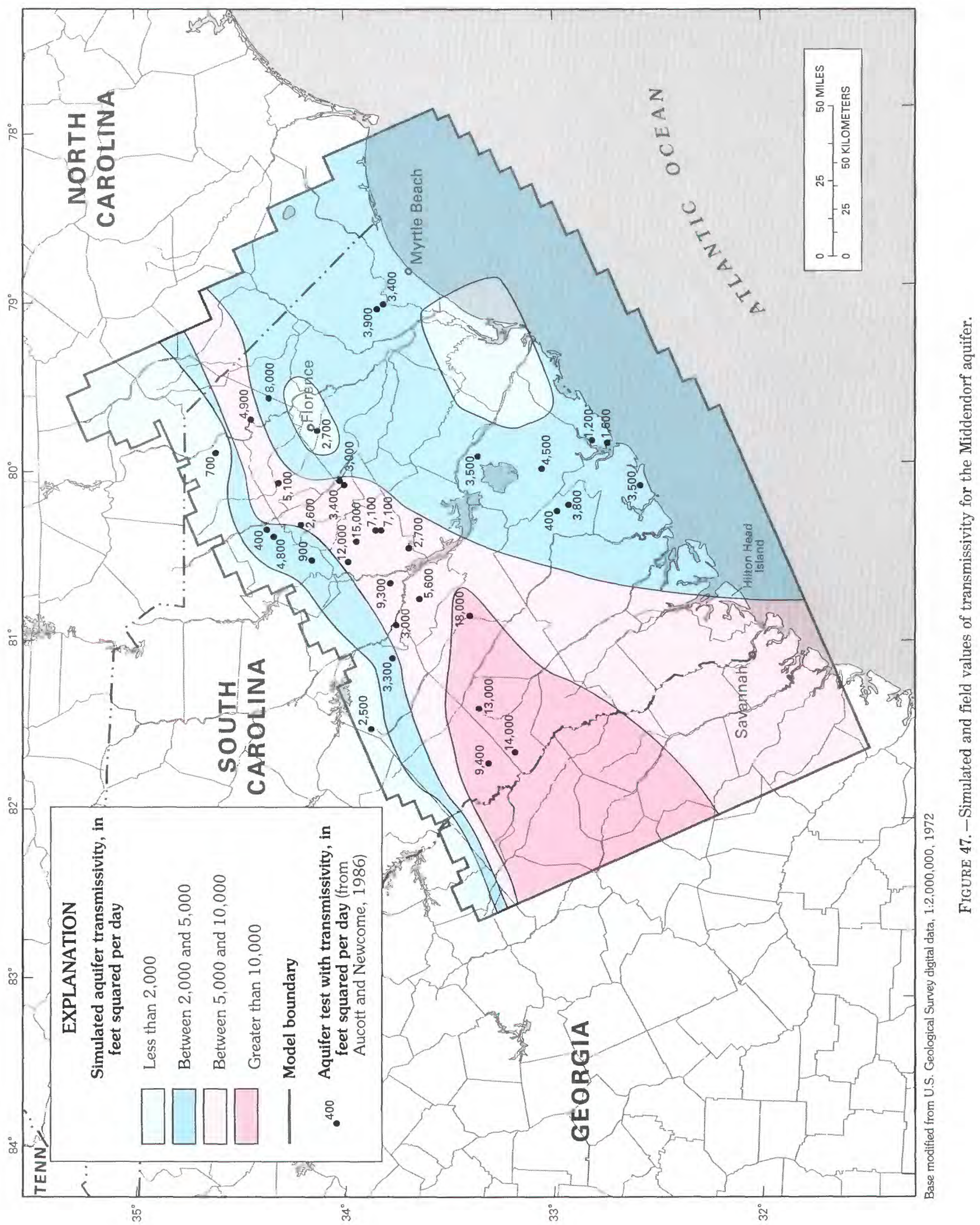




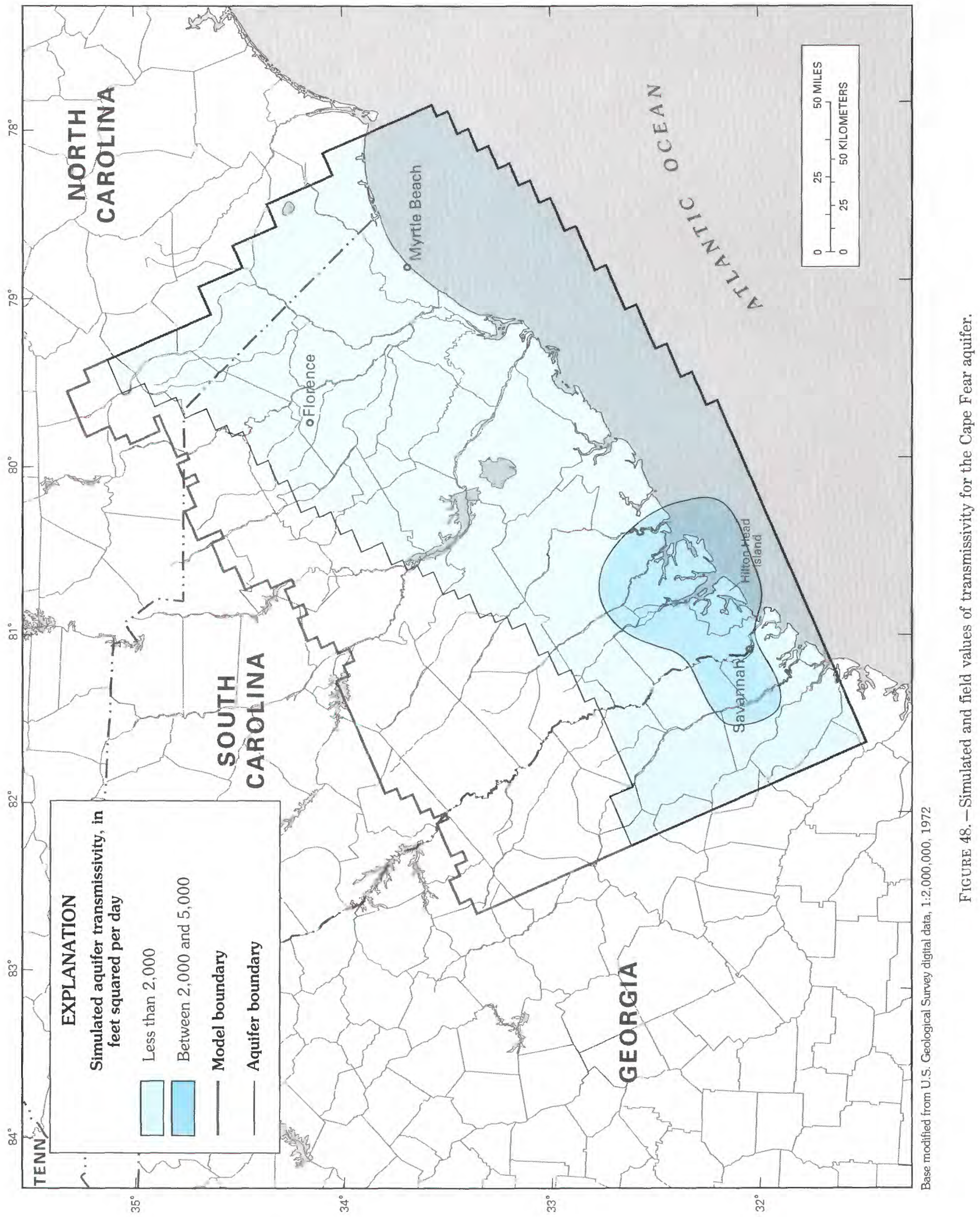


some question as to the ability of the model to determine the "effective" transmissivity of the Middendorf for the area. The reliability of the model as a predictive tool for the effects of future pumping in the Florence area is less certain because of this discrepancy between simulated and observed transmissivities. Large reductions in the transmissivity of the Middendorf aquifer in the Georgetown-Andrews area were made because a reevaluation of sparse data available in that area (specificcapacity tests and geophysical logs) suggested lower values.

Calibrated transmissivity values range from about 700 to 11,000 feet squared per day $\left(\mathrm{ft}^{2} / \mathrm{d}\right)$ for the Tertiary sand aquifer and the actively simulated part of the Floridan aquifer system; from about 400 to $11,000 \mathrm{ft}^{2} / \mathrm{d}$ for the Black Creek aquifer; from about 300 to 30,000 $\mathrm{ft}^{2} / \mathrm{d}$ for the Middendorf aquifer; and from about 1,100 to $3,600 \mathrm{ft}^{2} / \mathrm{d}$ for the Cape Fear aquifer. Transmissivity values are lowest near the updip limit of each aquifer due to thinning of the aquifer. Transmissivity distributions are not presented for the surficial aquifer and for part of the Floridan aquifer system because they were not actively simulated.

The transmissivity of the Tertiary sand aquifer and Floridan aquifer system increases downdip and from northwest to southeast along the Savannah River, through the Tertiary sand aquifer, and into the more permeable limestone of the Floridan aquifer system as described by Krause and Randolph (1989). The rapid increase is due to the coarse-grained material present in the Tertiary sand aquifer in this area and to the clasticcarbonate facies change. Increases in transmissivity are smaller from northeast to southwest, for example, from Berkeley County to Beaufort County, because in Berkeley, Charleston, and Dorchester Counties the Floridan aquifer system is composed of the Santee Limestone, which is only moderately permeable (Park, 1985; Aucott and Newcome, 1986). Transmissivity increases greatly in Beaufort and Jasper Counties, where the highly permeable Ocala Limestone composes the upper part of the Floridan aquifer system (Hayes, 1979; Krause and Randolph, 1989). Initial transmissivity values assigned to the Floridan aquifer system and Tertiary sand aquifer were not altered substantially during calibration of the predevelopment model, except for (1) increases made near the updip limit of the Tertiary sand aquifer, where sparse field data likely led to poor initial estimates and (2) increases in the Barnwell County, S.C., and Burke County, Ga., area that reflected field data acquired during model calibration.

Black Creek aquifer transmissivity varies generally as a sequence of bands parallel to the updip limit of the aquifer (fig. 46). Near the updip limit, the transmissivity is less than $2,000 \mathrm{ft}^{2} / \mathrm{d}$ but gradually increases toward the coast because of increased aquifer thickness. The coarser grained sediments composing this aquifer in the western part of the study area result in higher transmissivities there than to the east, where aquifer materials are much finer. Throughout most of the eastern part of the study area, Black Creek aquifer sediments are thin beds of fine sand interspersed with layers of clay. Because the aquifer thickness in the eastern part of the study area remains relatively constant, and because the aquifer materials are uniform there, the transmissivity is consistently between 2,000 and $5,000 \mathrm{ft}^{2} / \mathrm{d}$ in much of the eastern part of the study area. The major changes from initial estimates of Black Creek aquifer transmissivity made during calibration of the predevelopment model were an increase of transmissivity within $20 \mathrm{mi}$ of the updip limit and increases in most of the eastern part of the study area. The revised transmissivities in the eastern part of the study area correlate well with the transmissivity estimates for the Black Creek aquifer derived from aquifer-test and specific-capacity data.

The pattern of transmissivity distribution in the Middendorf aquifer (fig. 47) resembles the pattern of the Black Creek aquifer. In the Middendorf aquifer, transmissivities increase from a minimum at the Fall Line, which is the updip limit for most of the aquifer, to a maximum about one-third of the way toward the coast. As in the Black Creek aquifer, the transmissivity of the Middendorf aquifer is greater in the western than in the eastern part, primarily as a result of coarser aquifer sediments in the western part. Transmissivity values of the Middendorf aquifer generally are lower in parts of Florence, Marion, Georgetown, and Williamsburg Counties than elsewhere because of the relatively high clay content of the aquifer in these counties. Middendorf aquifer transmissivities generally decrease toward the coast but are greater than, or equal to, transmissivity values of the Black Creek aquifer in most areas. Aquifertest and specific-capacity data for the Middendorf aquifer are much sparser near the coast and near the updip limit of the aquifer than elsewhere.

Simulated transmissivity values of the Cape Fear aquifer are less than $2,000 \mathrm{ft}^{2} / \mathrm{d}$ nearly everywhere in the study area (fig. 48). The sparse specific-capacity and lithologic data available indicate that the transmissivity may even be less than the values derived from model calibration. Cape Fear aquifer transmissivities were increased during predevelopment model calibration to a value that was considered a reasonable upper limit, given the available data. As mentioned earlier, sensitivity testing indicates that the calibration could be further improved by increasing transmissivity even more. Because such increases are not supported by the field data, the transmissivity ranges presented on figure 48 are considered rough estimates. 
Leakance coefficients were adjusted extensively during predevelopment model calibration because (1) they were one of the parameters initially estimated with the least confidence, and (2) the simulation was sensitive to changes in the parameter. During the calibration of the transient model, three changes were made to the predevelopment calibrated values: leakance coefficients of the confining unit underlying the surficial aquifer were decreased by a factor of 10 in the Myrtle Beach-Georgetown area and near offshore areas; leakance coefficients of the confining unit between the Black Creek and Middendorf aquifers were decreased by a factor of 3 from the values used for the predevelopment model in the Myrtle Beach-Georgetown area and were decreased by a factor of between 2 and 10 in a band along the eastern part of the updip limit of the confining unit in the area of Dillon, Florence, and Sumter. All of these changes were made in order to improve the calibration.

Final calibrated values for the leakance coefficient, shown in figures 49 through 52 , range from $6 \times 10^{-9}$ to $3 \times 10^{-4}(\mathrm{ft} / \mathrm{d}) / \mathrm{ft}$. Assuming an average thickness of each confining unit of $100 \mathrm{ft}$, vertical hydraulic conductivity values range from about $6 \times 10^{-7}$ to $3 \times 10^{-2} \mathrm{ft} / \mathrm{d}$. In general, the leakance coefficient is greatest near the updip limit of most confining units, where they typically are thinnest and consist of coarse sediments, and least toward the coast, where most units have undergone a facies change to finer sediments. For example, all confining units have a low hydraulic conductivity at Charleston: leakance coefficient values there for all confining beds are within the range of $6 \times 10^{-9}$ and $6 \times 10^{-8}(\mathrm{ft} / \mathrm{d}) / \mathrm{ft}$. Although the relative distributions of leakance coefficients seem reasonable when compared to geologic information (Colquhoun and others, 1983; Aucott, Davis, and Speiran, 1987), few data are available to provide quantitative verification of these values.

The simulated leakance coefficient of the confining unit underlying the surficial aquifer ranges between $6.0 \times 10^{-8}$ and $6.0 \times 10^{-5}(\mathrm{ft} / \mathrm{d}) / \mathrm{ft}$. Leakance coefficients are greatest near the updip limit of the surficial aquifer and decrease toward the coast (fig. 49). The leakance of this unit is least in the southern part of the study area-in southern Colleton, Dorchester, and southwestern Charleston Counties, where it contains the upper part of the Cooper Group (Colquhoun and others, 1983).

The simulated leakance coefficient of the confining bed between the Floridan aquifer system-Tertiary sand aquifer and the Black Creek aquifer varies over a wide range: between $8.5 \times 10^{-9}$ and $1.2 \times 10^{-4}(\mathrm{ft} / \mathrm{d}) / \mathrm{ft}$. It is greatest near the updip limit of the confining unit and decreases rapidly toward the coast (fig. 50). It varies because the Black Mingo Formation of Paleocene age that is part of this confining unit is less clayey and thinner near its outcrop to the northeast than it is in the subsurface to the southeast. As the Floridan aquifer system, Tertiary sand aquifer, and Paleocene confining clays pinch out to the northeast, the confining unit overlying the Black Creek aquifer consists of part of the Cretaceous Peedee Formation. This confining unit is leakier than the Paleocene clays. These model results support the general hypothesis, discussed previously in the section of this report describing the predevelopment flow system, that the direction of flow in the aquifers in Cretaceous rocks of the lower Coastal Plain is controlled at least in part by the east-west difference in the leakance coefficient of this confining unit.

An interesting variation, again from west to east, occurs in the confining unit between the Black Creek and Middendorf aquifers (fig. 51). Final results for transient simulation show that this confining unit is less permeable in the western part of the study area than in the eastern part. This variation in permeability corresponds well with the available data that indicate head and waterquality differences between the Black Creek and Middendorf aquifers in the western part of the area are greater than differences found to the east (figs. 16, 17, and 28-31). Leakance coefficient values for this confining unit range from $6.0 \times 10^{-9}$ to $3.0 \times 10^{-4}(\mathrm{ft} / \mathrm{d}) / \mathrm{ft}$.

The confining unit between the Middendorf and Cape Fear aquifers has low permeability everywhere; simulated leakance coefficients range from $9.1 \times 10^{-9}$ to $9.1 \times 10^{-6}(\mathrm{ft} / \mathrm{d}$ )/ft (fig. 52). Simulated leakance coefficients are lowest in the downdip half of the confining unit. The relatively poor hydraulic connection between the Middendorf and Cape Fear aquifers that is due to the low permeability of this confining unit results in the long flow paths, parallel to the coast, in the Cape Fear aquifer as previously described.

Because little reliable areal information on storage coefficients is available and because the transient simulation is relatively insensitive to large changes in this parameter, a very simplified distribution of storage coefficient values was used in the model (fig. 53). In constructing this distribution, it was assumed that aquifers were under unconfined conditions (at least in response to significant pumping stress) in roughly the updip half of each of their outcrop areas. In these areas, a uniform storage coefficient of 0.15 was used to represent the specific yield. Stricker (1983) used a specific yield of 0.15 in her analysis of base flow of streams in the Southeastern Coastal Plain. Confined conditions were assumed to exist in the downdip half of all aquifer outcrop areas because of the vertical heterogeneities of the Coastal Plain sediments. Although this treatment of outcrop areas is a simplification of actual conditions, it tended to produce reasonable results for pumping centers in or near outcrop areas despite inherent problems in simulating the shallow flow systems there. In all areas 


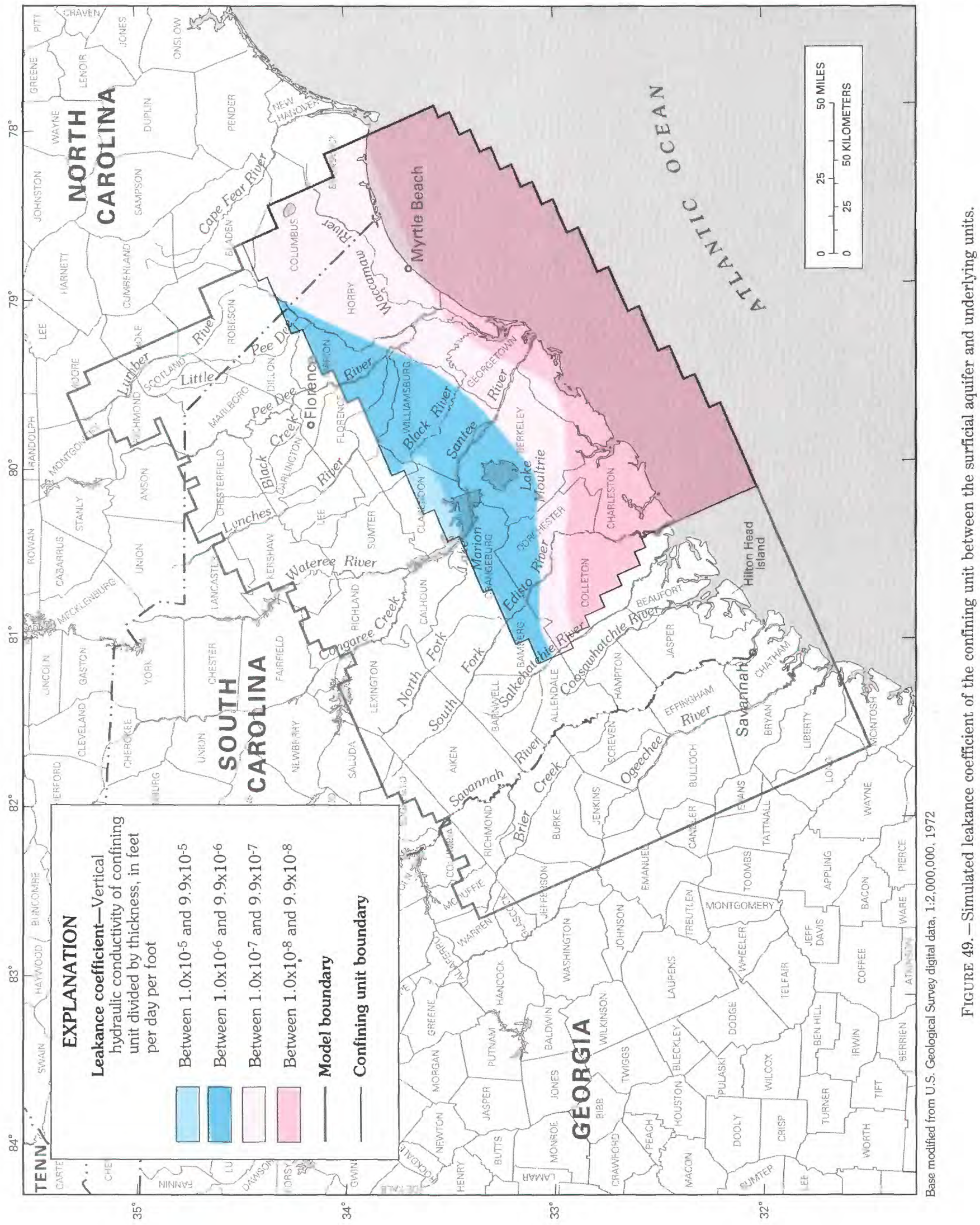




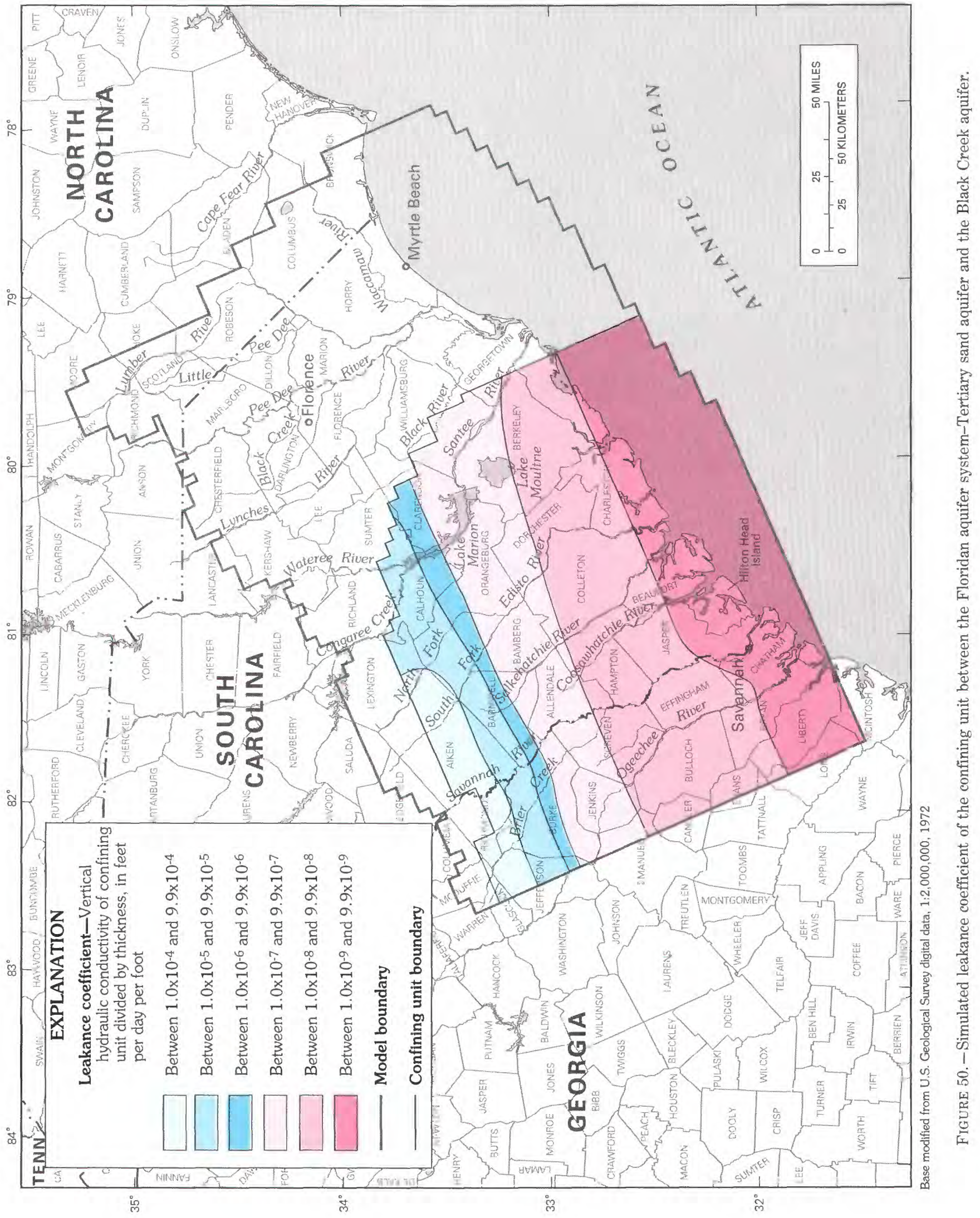




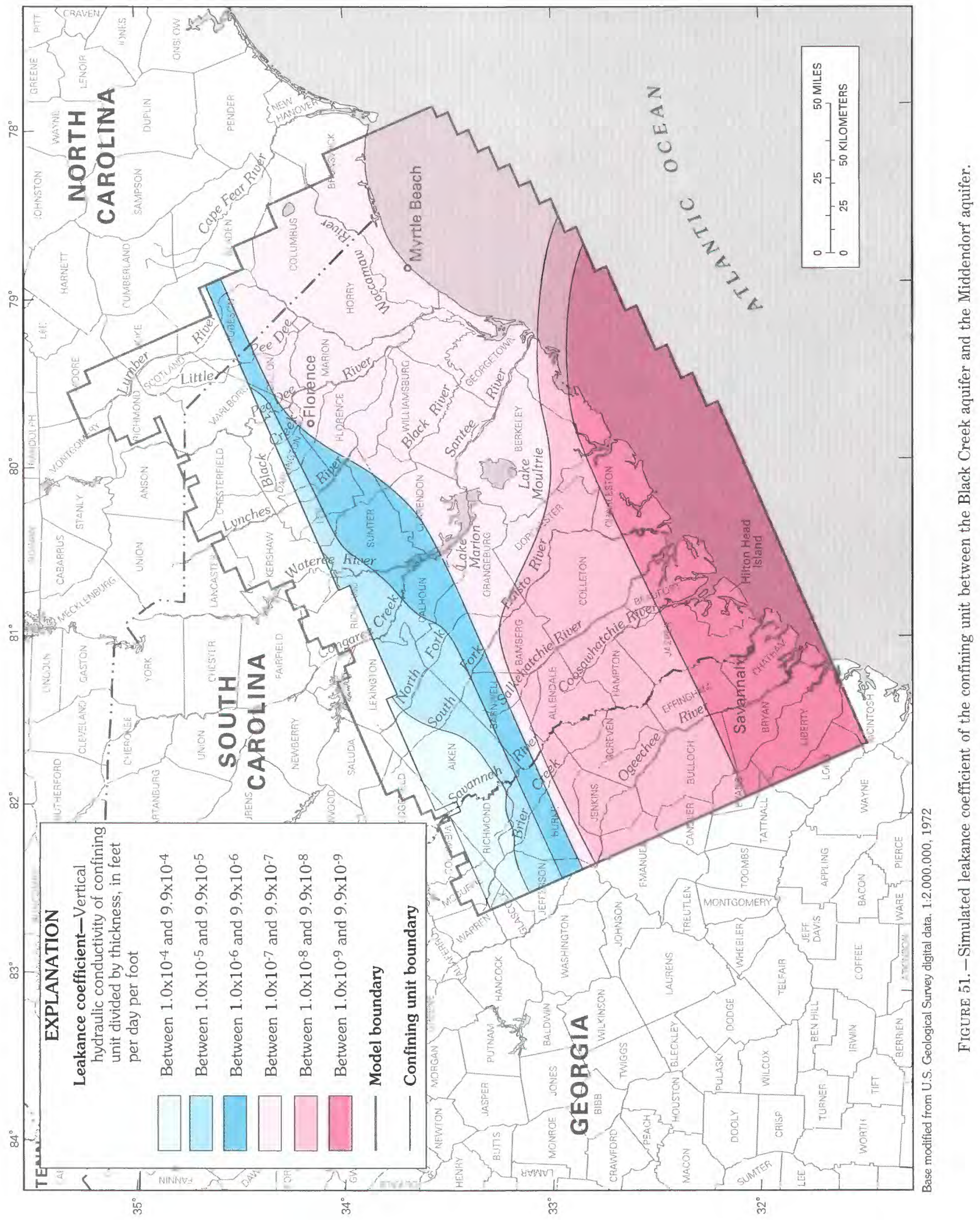




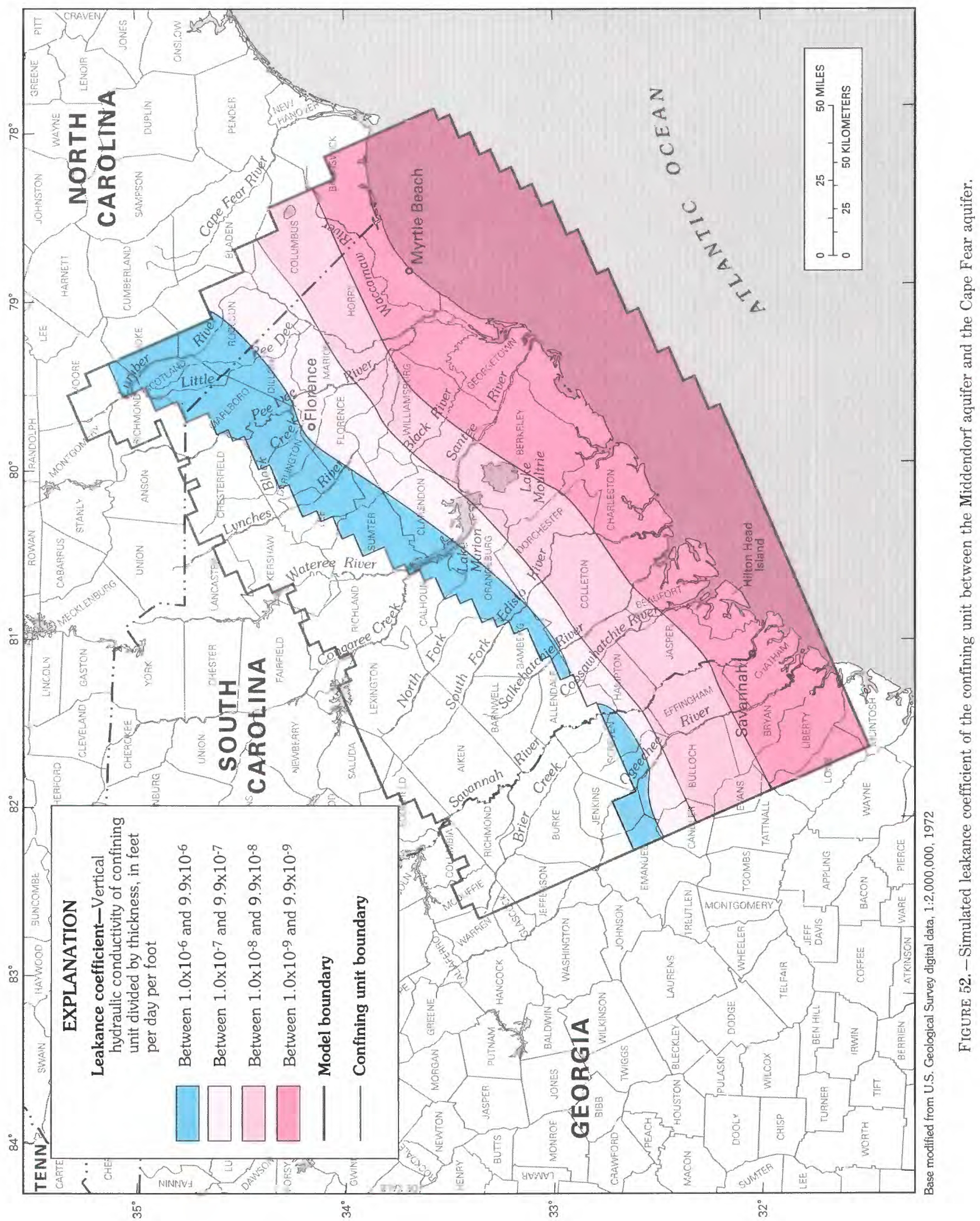




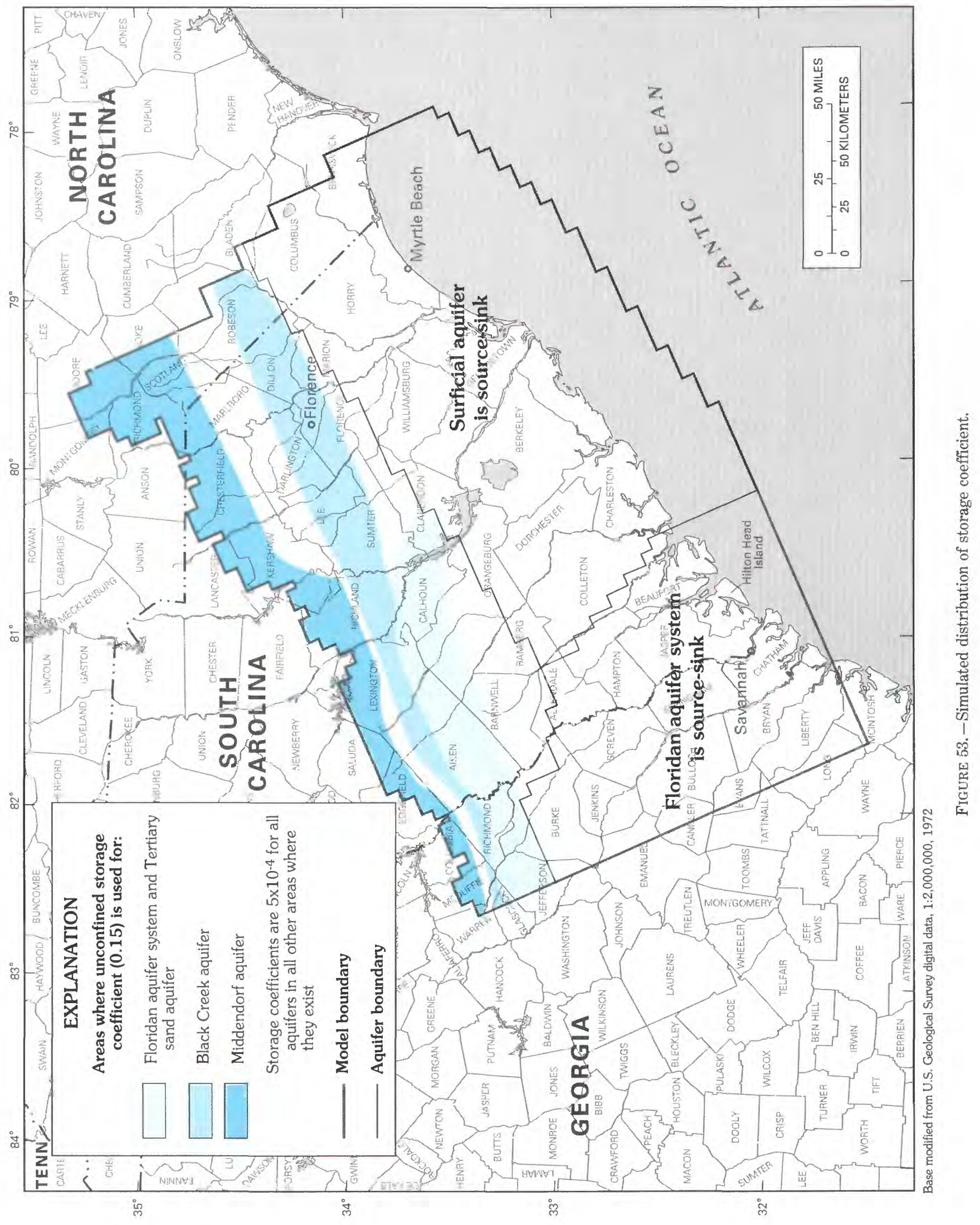


where confined conditions were assumed, a uniform storage coefficient of 0.0005 was used in the final simulation. The initial value of 0.0003 was modified somewhat to achieve a better calibration. The final value of 0.0005 was within the range of reported values.

Streambed conductance, defined by McDonald and Harbaugh (1984) as the streambed hydraulic conductivity multiplied by the streambed area and divided by the streambed thickness, ranged from about 10,000 to $100,000 \mathrm{ft}^{2} / \mathrm{d}$ in the model. The conductances of most streambeds were greater near the Fall Line than downstream. On the basis of an assumed average stream length per grid block of $4 \mathrm{mi}$, an average stream width of $500 \mathrm{ft}$, and an average streambed thickness of $10 \mathrm{ft}$, the resulting range in streambed hydraulic conductivity is about 0.01 to $0.1 \mathrm{ft} / \mathrm{d}$. These values are 2 or 3 orders of magnitude lower than simulated hydraulic conductivities for aquifers in the study area (about 5-100 ft/d). Streambed hydraulic conductivities generally fall at the upper limit of values for hydraulic conductivities of confining units (between $6 \times 10^{-7}$ and $3 \times 10^{-2} \mathrm{ft} / \mathrm{d}$ ) within the study area and are generally representative of literature values for silt (Freeze and Cherry, 1979). The values of streambed hydraulic conductivity seem reasonable considering the relatively low gradient of rivers in the Coastal Plain. These rivers generally have poorly scoured, silty or clayey beds that act as leaky confining beds.

No changes were made in streambed conductance during the calibration of the transient model. Although the overall model calibration is relatively insensitive to increases in streambed conductance, as indicated by sensitivity analysis (fig. 43), the ability of the model to reproduce observed heads in the vicinity of the upper Coastal Plain rivers indicates that key parameters in that area, including streambed conductance, are reasonable.

The simulated average recharge to or discharge from the deep ground-water flow system, prior to development, is shown in figure 54 . The rates of recharge and discharge shown in this figure represent the deep flow system as previously discussed in the section of this report describing the predevelopment flow system, rather than the rates for the total flow system. Efforts to compute total recharge would require inclusion of the shallow flow system into the simulation, a feat that could not be done owing to the coarse mesh of the model and that is beyond the scope of this report. Recharge used to calculate the rates shown in figure 54 was derived from leakage from the overlying surficial aquifer in the eastern part of the lower Coastal Plain, from the source-sink part of the Floridan aquifer system in the western part of the lower Coastal Plain, and from the direct input of recharge to the model in the upper Coastal Plain.
Recharge to the deep flow system occurs primarily in updip interstream areas and varies from 0 to $4 \mathrm{in} / \mathrm{yr}$ in the study area. Simulated recharge rates are greatest in the western part of the upper Coastal Plain. This finding is supported by the generally greater base flows of small streams (Bloxham, 1976; Stricker, 1983) and greater deep system flow to large streams in this area (table 4). Lower rates of recharge occur in the eastern part of the upper Coastal Plain as well as in small isolated parts of the lower Coastal Plain. Recharge to the deep flow system is possible in the lower Coastal Plain only in areas of relatively high land-surface altitude, such as in northern Horry, Columbus, and Berkeley Counties. Lake Moultrie in Berkeley County is bounded by levees and acts as a source of recharge, as does the topographically high area adjacent to the lake.

Recharge in the transient model was held constant at the rates used in the predevelopment simulation. It would be expected that when ground-water withdrawals cause water-level declines, the source of some of that water would be from additional (induced) recharge or flow from the shallow flow system to the deep flow system. Because of the scale and nature of this and other Southeastern Coastal Plain RASA models, this flow could not be simulated. This problem causes the simulation to be a poor representation of the system near the Fall Line but less of a problem away from the Fall Line. Most of the pumpage in this model occurs in confined aquifers away from the Fall Line in areas such as Florence, Sumter, the Savannah River Plant, and Myrtle Beach.

Simulated discharge from the deep flow system varied from 0 to $19 \mathrm{in} / \mathrm{yr}$ (fig. 54) and is primarily to large streams in the upper Coastal Plain. Discharge generally is greatest to streams in the western part of the upper Coastal Plain and also occurs as diffuse upward leakage to the surficial aquifer in most of the lower Coastal Plain and to the Atlantic Ocean. These rates are less than 1 in/yr everywhere. Discharge by upward leakage and to streams decreased nearly everywhere in the study area between predevelopment and 1982 conditions. The largest decreases were to the large upper Coastal Plain rivers, especially near large pumping centers.

No independent verification by field measurement was possible for recharge. Although heads and streamflows were used as calibration criteria, recharge values should be considered one of the least reliable of the calibrated parameters. Discharge rates are somewhat more reliable despite the coarseness of the calculations for discharge from the aquifers to streams (Aucott, Meadows, and Patterson, 1987).

Figures 55 through 58 show the simulated potentiometric surfaces of the Coastal Plain aquifers at the end of transient simulation (November 1982). Although not 


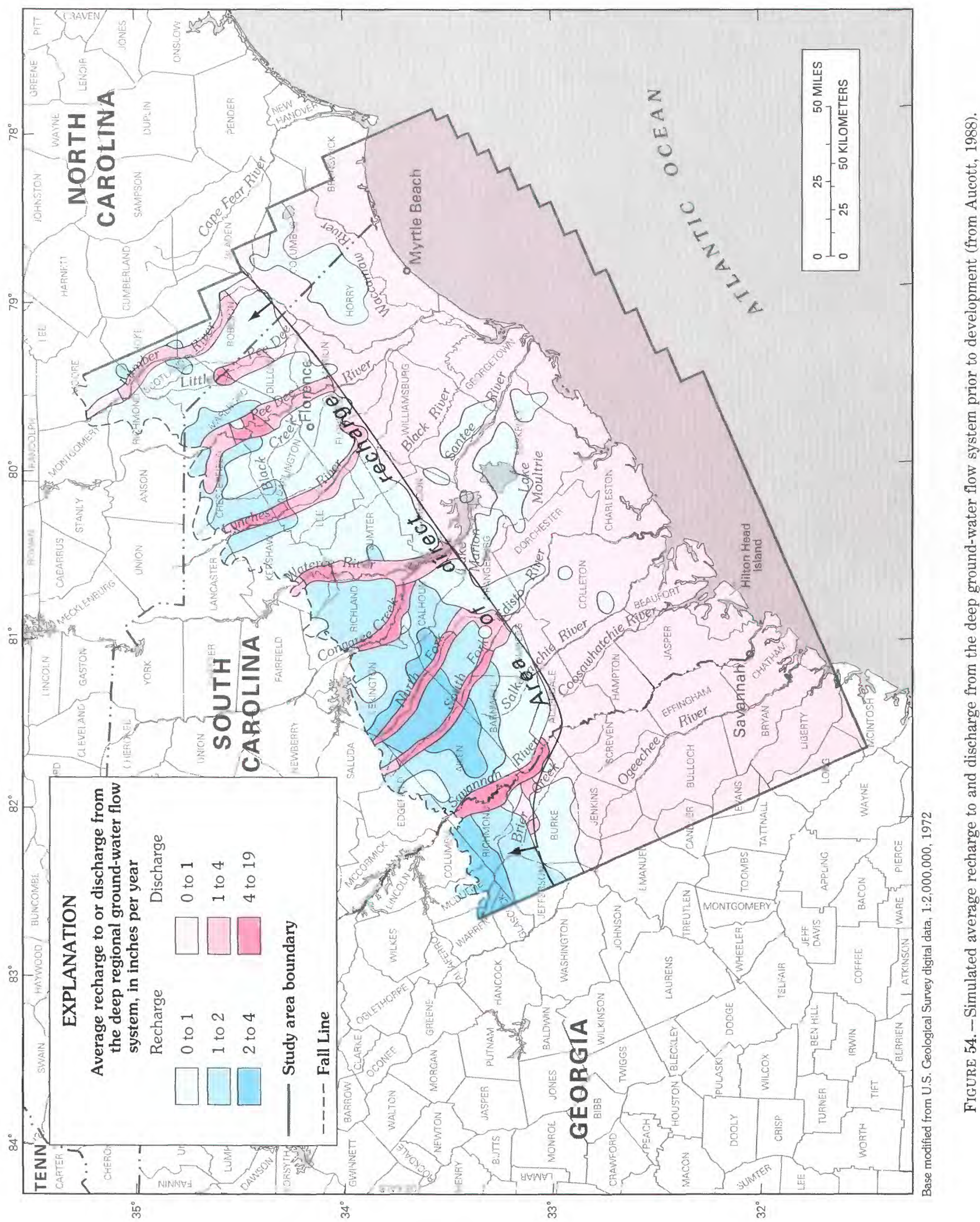


TABLE 4.-Computed flow from the deep aquifer system to rivers

\begin{tabular}{|c|c|c|c|c|}
\hline River $^{1}$ & $\begin{array}{l}\text { Streamflow } \\
\text { stations }^{2}\end{array}$ & $\begin{array}{l}\text { Computed deep system } \\
\text { aquifer-to-river flow }{ }^{3} \\
\text { (cubic feet per second) }\end{array}$ & $\begin{array}{l}\text { Miles } \\
\text { between } \\
\text { streamflow } \\
\text { stations }\end{array}$ & $\begin{array}{l}\text { Computed deep system } \\
\text { aquifer-to-river flow } \\
\text { per river mile } \\
\text { (cubic feet per } \\
\text { second per mile) }\end{array}$ \\
\hline Savannah & 1975 to 1970 & 154 & 58.2 & 2.65 \\
\hline South Fork Edisto & 1730 to 1725 & 45 & 30.7 & 1.47 \\
\hline North Fork Edisto & 1735 to 1731.7 & 100 & 48.2 & 2.07 \\
\hline Pee Dee & 1310 to 1290 & 101 & 78.3 & 1.29 \\
\hline Lumber & 1336.4 to 1329.43 & 29 & 39.7 & .73 \\
\hline
\end{tabular}

\footnotetext{
${ }^{1}$ Upper Coastal Plain reach.

${ }^{2}$ See figure 19 for streamflow station locations.

${ }^{3}$ From Aucott, Meadows, and Patterson (1987).
}

used for calibration because head-change maps are more rigorous criteria for transient calibration than head at a single time, these simulated potentiometric surfaces are a useful output of the transient model. The general flow patterns indicated by the simulated surfaces are similar to flow patterns derived from field data (figs. 21 through 23). The single exception is the flow pattern in the Cape Fear aquifer in the vicinity of Horry County identified previously in the predevelopment model (Aucott, 1988, p. 22).

\section{SIMULATED 1982 WATER BUDGET}

The simulated water budget for the deep flow system at the end of transient simulation (November 1982) is summarized in figure 59. Simulated recharge to the ground-water flow system includes 793 cubic feet per second $\left(\mathrm{ft}^{3} / \mathrm{s}\right)$ of direct recharge in outcrop areas and 24 $\mathrm{ft}^{3} / \mathrm{s}$ of downward leakage from the overlying surficial aquifer. Simulated discharge is $660 \mathrm{ft}^{3} / \mathrm{s}$ to rivers in the upper Coastal Plain and $19 \mathrm{ft}^{3} / \mathrm{s}$ to the overlying surficial aquifer in the lower Coastal Plain. A total of $249 \mathrm{ft}^{3} / \mathrm{s}$ is pumped from the ground-water flow system. Leakage from and to the source-sink part of the Floridan aquifer system is $6 \mathrm{ft}^{3} / \mathrm{s}$ and $9 \mathrm{ft}^{3} / \mathrm{s}$, respectively. Total lateral flow across all boundaries in all active layers is $34 \mathrm{ft}^{3} / \mathrm{s}$ into the modeled area and $30 \mathrm{ft}^{3} / \mathrm{s}$ out of the modeled area. A net amount of $110 \mathrm{ft}^{3} / \mathrm{s}$ is derived from storage. Total outflow from the deep ground-water flow system of the Coastal Plain aquifers was $967 \mathrm{ft}^{3} / \mathrm{s}$ at the end of the transient simulation period (fig. 59).

Flow between aquifers is quantitatively important to the total flow system (fig. 59). The Cape Fear aquifer, through which little water flows, is not a significant part of the flow system. Much of the downward leakage from the source-sink parts of the surficial aquifer and Floridan aquifer system occurs near their respective updip limits in the upper Coastal Plain. Upward leakage to sinks occurs over a large area throughout the lower Coastal Plain.

The total flow across the lateral boundaries of $34 \mathrm{ft}^{3} / \mathrm{s}$ into and $30 \mathrm{ft}^{3} / \mathrm{s}$ out of the active model area is of minor importance in comparison with the $967 \mathrm{ft}^{3} / \mathrm{s}$ discharging from the overall flow system. Thus, the lateral boundaries selected seem to be good choices because they have negligible regional influence on the flow system. Boundary flows, however, can be important in the functioning of parts of the flow system, especially in the vicinity of the boundaries.

The total simulated outflow of $967 \mathrm{ft}^{3} / \mathrm{s}$ represents only flow in the deep flow system. Flow in the shallow system, such as that to small streams in the upper Coastal Plain, was not simulated by this model because of scale. Total flow in the entire ground-water flow system (shallow and deep) is much greater than flow simulated for the deep system alone. A general relation between the total ground-water flow in the system and deep flow, as computed by the model, can be seen by the relation of total base flow to deep flow discharging to major streams in the upper Coastal Plain. Average total base flow of six small streams in the upper Coastal Plain of South Carolina was calculated to be $0.9\left(\mathrm{ft}^{3} / \mathrm{s}\right) / \mathrm{mi}^{2}$ by Stricker (1983). Deep flow discharging to six large streams in the upper Coastal Plain of South Carolina and North Carolina was calculated to be $0.11\left(\mathrm{ft}^{3} / \mathrm{s}\right) / \mathrm{mi}^{2}$ by Aucott, Meadows, and Patterson (1987). These values clearly indicate that the deep flow simulated by the model represents only a small part of the entire flow system.

The changes in ground-water flow between the predevelopment model and the transient model are indicated in figure 60 . The increased discharge due to pumpage of 249 $\mathrm{ft}^{3} / \mathrm{s}$ from wells is balanced by a reduction of $110 \mathrm{ft}^{3} / \mathrm{s}$ in ground-water storage, a decrease of $67 \mathrm{ft}^{3} / \mathrm{s}$ in aquiferto-river discharge, a net increase of $44 \mathrm{ft}^{3} / \mathrm{s}$ inflow from source-sinks, and a net increase of $28 \mathrm{ft}^{3} / \mathrm{s}$ in boundary inflow. Reductions of ground water in storage and reduc- 


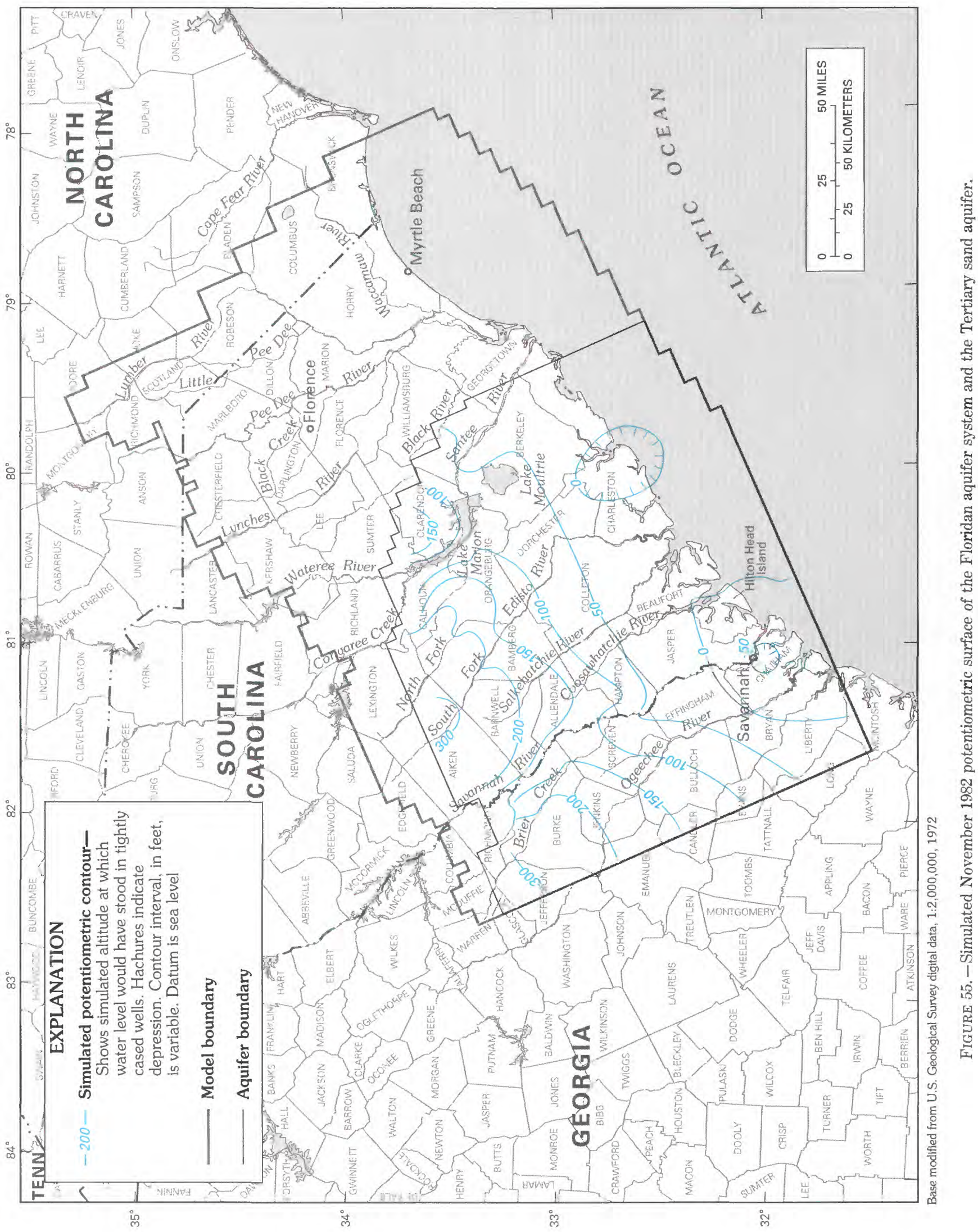




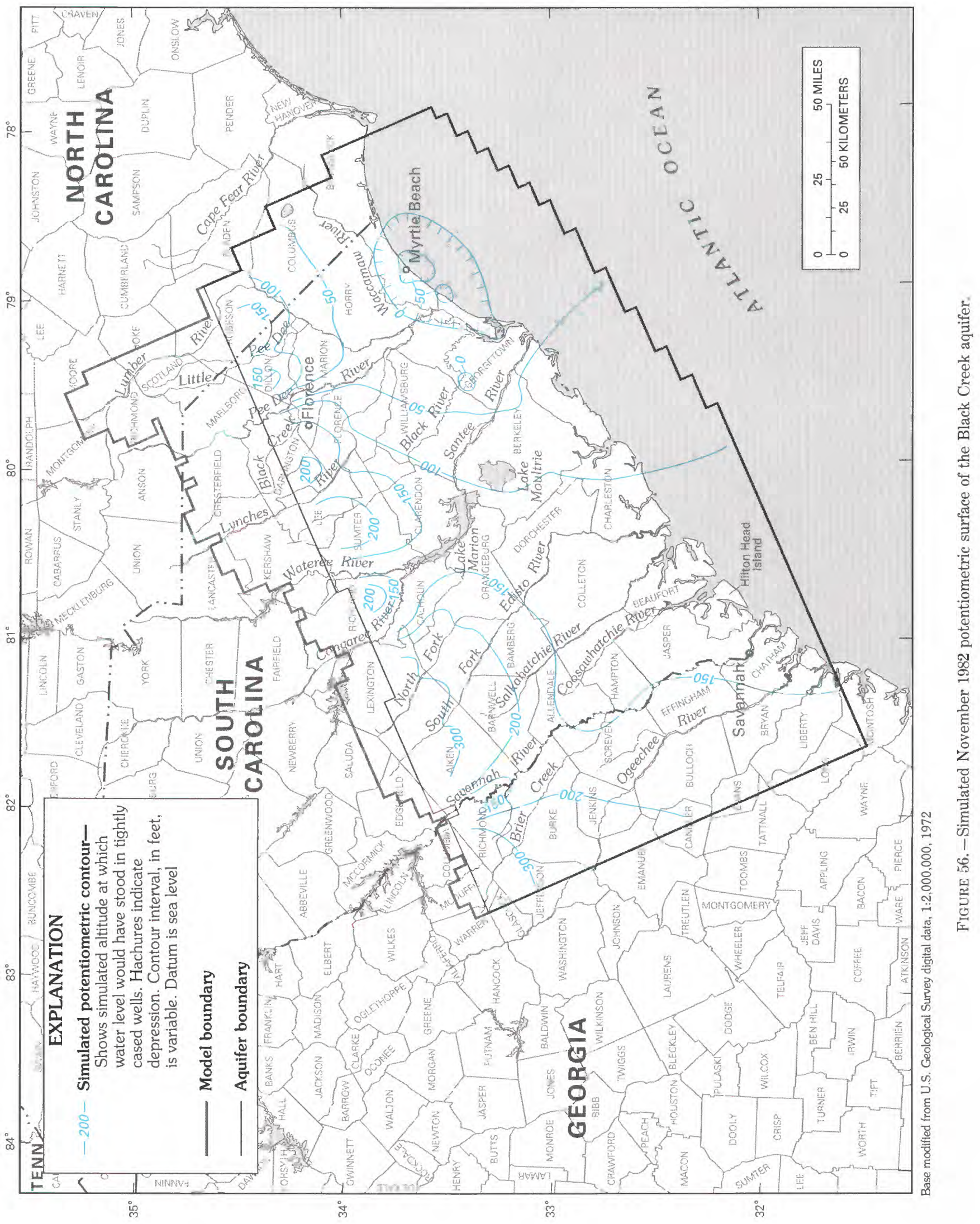




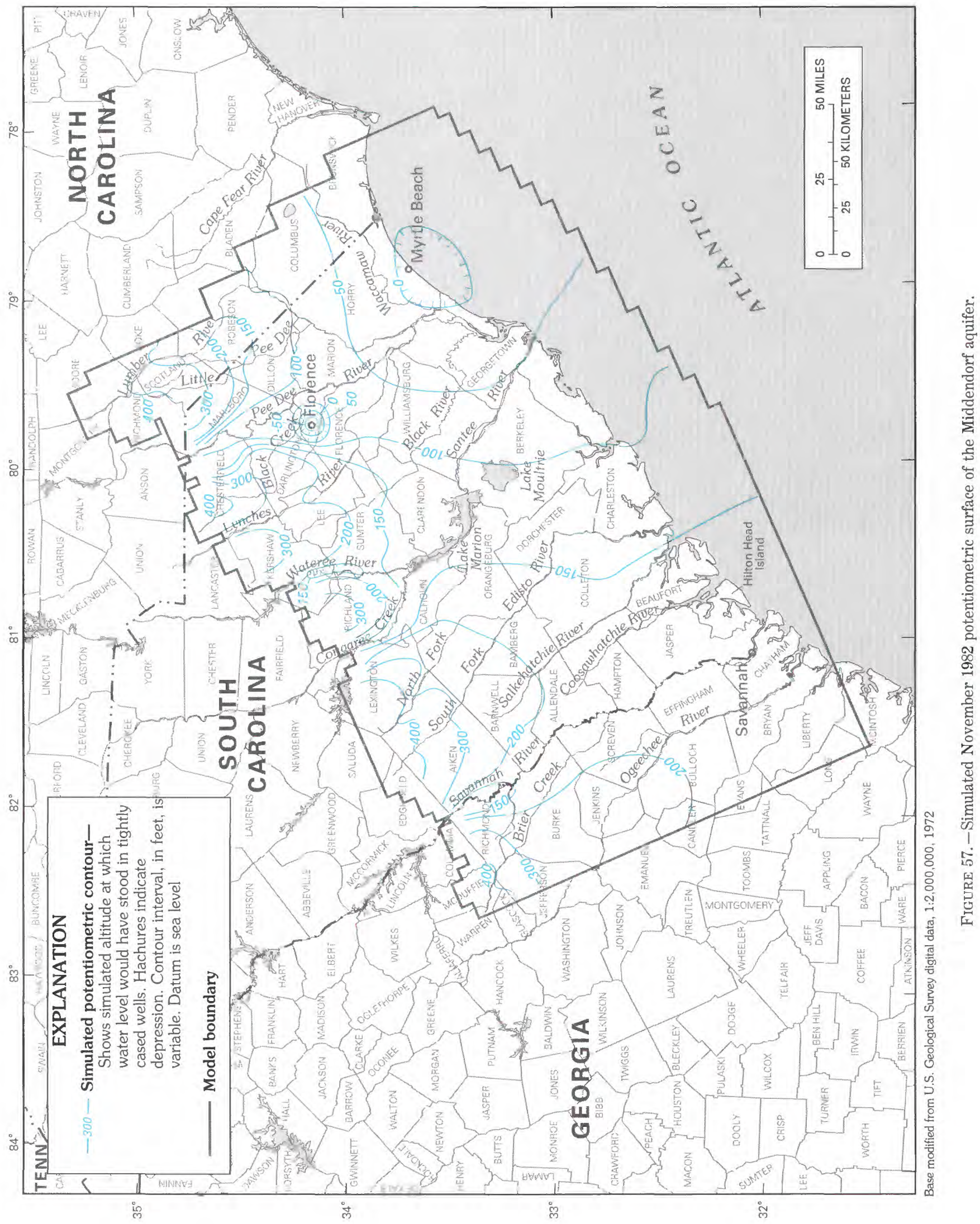




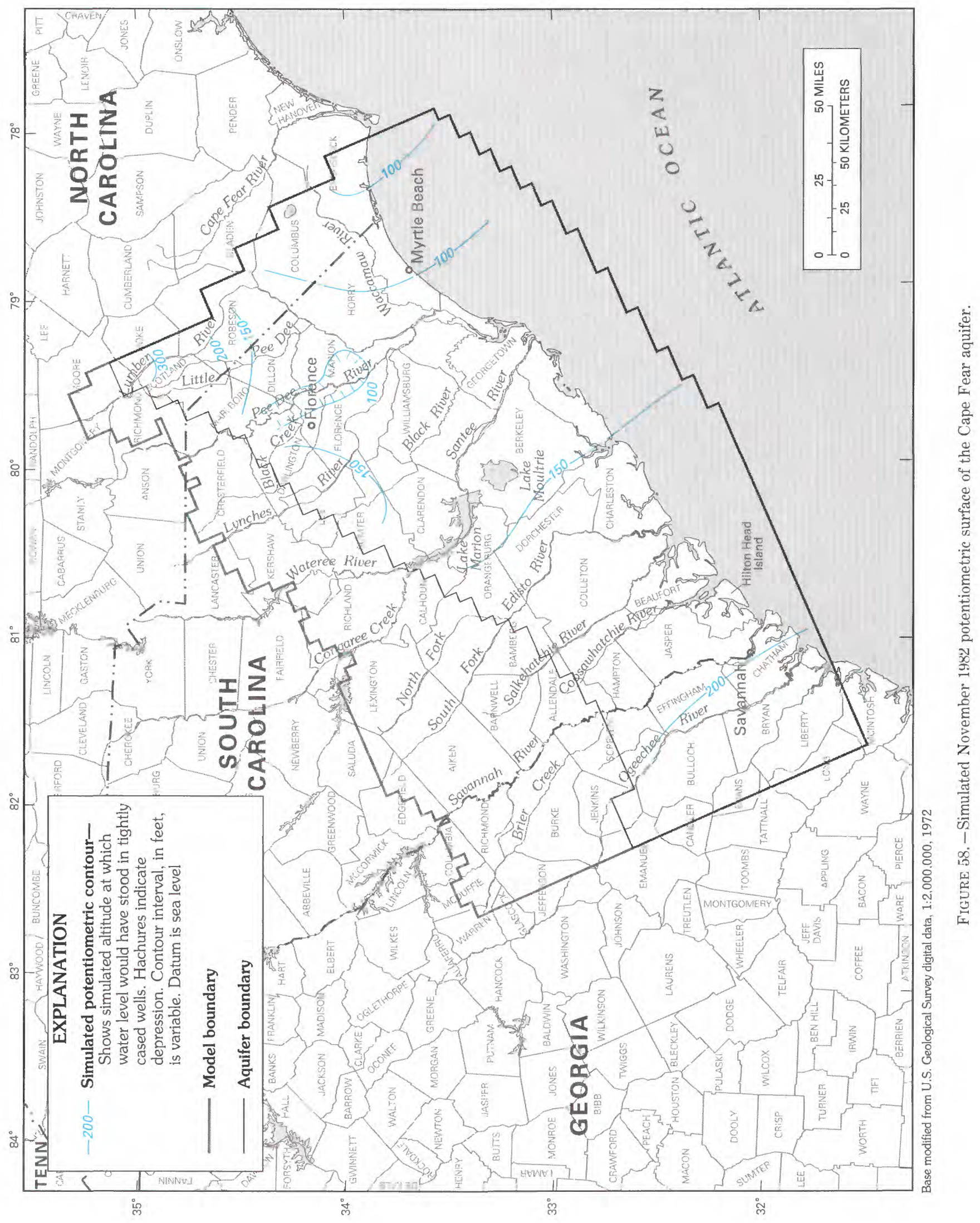




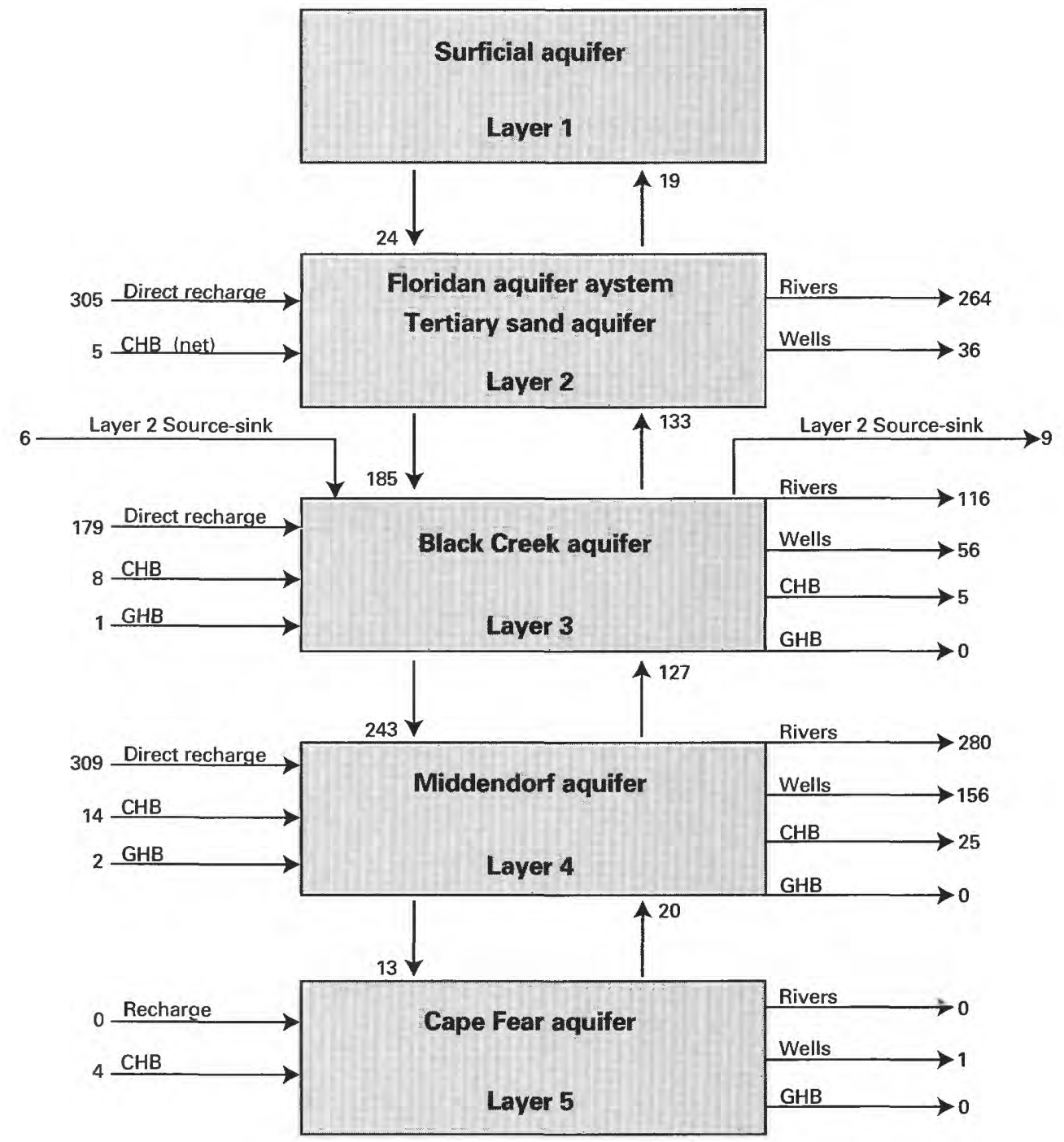

The five model layers are represented by the five boxes in the center of the figure. Items to the left of the boxes, with arrows pointing into each box represent inflow to the model and a particular layer. Items to the right of the boxes with arrows pointing out from each box represent flow out of the model and a particular layer. GHB is flow from or to general-head boundary nodes, and CHB is flow from or to constant-head boundary nodes. Numbers between the boxes represent flow between the aquifers through confining units. All flows are in cubic feet per second. A net amount of $110 \mathrm{ft}^{3} / \mathrm{s}$ is derived from storage.

Figure 59.-Simulated water budget for the deep flow system, November 1982. 


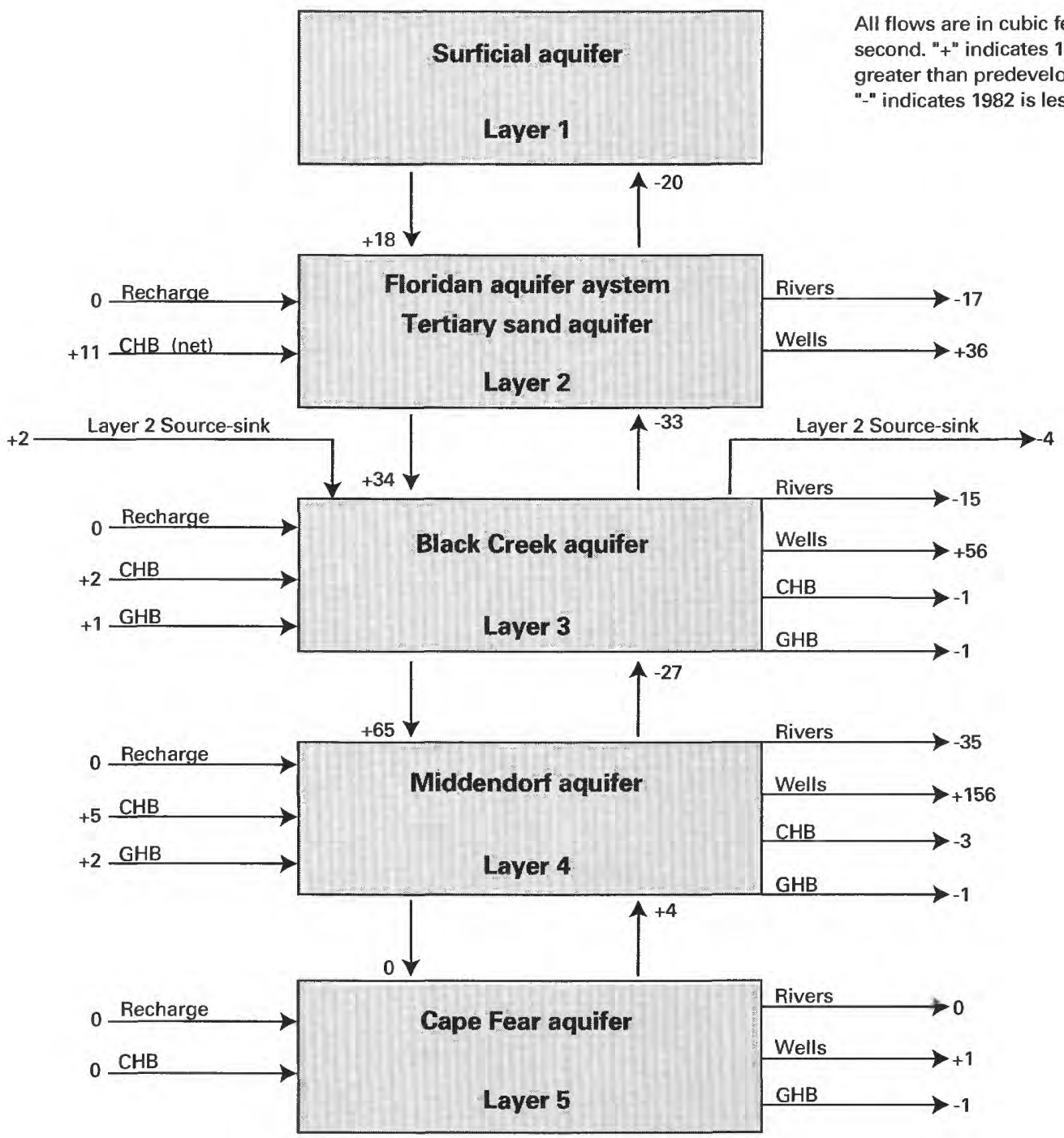

The five model layers are represented by the five boxes in the center of the figure. Items to the left of the boxes, with arrows pointing into each box, represent inflow to the model and a particular layer. Items to the right of the boxes with arrows pointing out from each box represent flow out of the model and a particular layer. GHB is flow from or to general-head boundary nodes, and CHB is flow from or to constant-head boundary nodes. Numbers between the boxes represent flow between the aquifers through confining units. A net amount of $110 \mathrm{ft}^{3} / \mathrm{s}$ is derived from storage.

FIGURE 60. - Change in simulated water budget for the deep flow system between predevelopment and November 1982. 
TABLE 5.-Observed and simulated flow from the deep aquifer system to rivers prior to development and in November 1982 and net change

[Values in cubic feet per second]

\begin{tabular}{lcccr}
\hline \multicolumn{1}{c}{ River $^{1}$} & $\begin{array}{c}\text { Computed deep system } \\
\text { aquifer-to-river flow }\end{array}$ & $\begin{array}{c}\text { Simulated pre- } \\
\text { development flow }\end{array}$ & $\begin{array}{c}\text { Simulated } \\
\text { November 1982 flow }\end{array}$ & $\begin{array}{c}\text { Simulated } \\
\text { change }\end{array}$ \\
\hline Savannah & 154 & 134 & 116 & -18 \\
South Fork Edisto & 45 & 42 & 39 & -3 \\
North Fork Edisto & 100 & 79 & 79 & 0 \\
Pee Dee & 101 & 70 & 61 & -9 \\
Lumber & 29 & 28 & 27 & -1 \\
\hline
\end{tabular}

${ }^{1}$ Upper Coastal Plain reach.

${ }^{2}$ From Aucott, Meadows, and Patterson (1987).

${ }^{3}$ From Aucott (1988)

tions in aquifer-to-river discharge represent most of the water withdrawn from the system due to pumpage.

Simulated aquifer-to-river discharge decreased from predevelopment to November 1982 in the river reaches of the upper Coastal Plain (table 5, fig. 19). Decreases were greatest in the Savannah and Pee Dee Rivers, which are near the large pumping centers of the Savannah River Plant and Florence, respectively.

Water derived from storage, net increases in leakage from overlying source-sinks, and inflow across boundaries are the dominant sources of water for pumping centers in the Myrtle Beach area. Decrease in flow from the aquifers to upper Coastal Plain rivers and water derived from storage are the dominant sources for upper Coastal Plain pumping centers such as the city of Florence. The decrease in net storage indicates that the flow system had not attained a steady state at the end of the 1982 transient simulation.

\section{SUMMARY AND CONCLUSIONS}

A wedge of sand, silt, clay, and limestone is present beneath the Coastal Plain of South Carolina and adjacent parts of Georgia and North Carolina. These sediments have been subdivided into six regional water-bearing units: the surficial aquifer, the Floridan aquifer system, the Tertiary sand aquifer, the Black Creek aquifer, the Middendorf aquifer, and the Cape Fear aquifer. Intervening confining units separate the aquifers, except for the Floridan aquifer system and the Tertiary sand aquifer, which together function as a single hydrologic unit.

Prior to development, the ground-water flow system was approximately at steady state. The sources of recharge to the Coastal Plain aquifers were precipitation in the aquifer outcrop areas and leakage from overlying and underlying aquifers. Discharge from the aquifers was to streams, to overlying and underlying aquifers, and to the ocean. The ground-water flow system in all aquifers prior to development was dominated in the upper Coastal Plain by flow toward rivers and streams. As a result of development of the aquifers, the groundwater flow system is no longer in steady state. Major declines in head, centered in the Florence and Myrtle Beach-Georgetown areas, have occurred in the Middendorf and Black Creek aquifers in eastern South Carolina. Drawdowns have also occurred in the Floridan aquifer system in the Savannah-Hilton Head and CharlestonSummerville areas and in the Black Creek aquifer in Allendale County. Relatively minor head declines in the Middendorf aquifer have occurred near the large pumping centers in the Sumter and the Savannah River Plant areas.

The quality of ground water from the Coastal Plain aquifers of South Carolina generally is acceptable for most uses in most areas. The quality of ground water in most aquifers ranges from low concentrations of dissolved solids and no dominant constituents in the recharge areas, to a calcium- or sodium-bicarbonate-type water throughout most of the Coastal Plain, to sodiumchloride-type water near the coast. Existing or potential water-quality problems that locally inhibit or restrict the use of ground water include high concentrations of chloride resulting from unflushed seawater or saltwater encroachment, high concentrations of fluoride and iron, low $\mathrm{pH}$, and water-quality changes resulting from human activities.

A ground-water flow model, which has an evenly spaced grid mesh of $4 \mathrm{mi}$, was constructed to simulate the predevelopment flow system. Because the intent was to study regional flow systems, and the model grid size precludes simulation of the complexities involved with shallow flow systems, only the deep flow system was simulated. No-flow boundaries were used to represent the updip limit of the units, the base of the Coastal Plain sediments, and the saltwater-freshwater interface. The lateral flow boundaries in Georgia and North Carolina 
were modeled predominantly as constant-head boundaries. The surficial aquifer and parts of the Floridan aquifer system previously modeled in other studies were treated as source-sink layers and were simulated with constant heads.

After the predevelopment (steady-state) model was calibrated, a model was constructed and calibrated to represent transient conditions from predevelopment to November 1982. New input data for the model included historical pumpage data and aquifer storage coefficients. A general-head boundary was used for parts of the lateral and saltwater-freshwater interface boundaries located near large pumping centers. The transient model was calibrated by using observed head declines between predevelopment and 1982 conditions, along with waterlevel data from selected hydrographs for wells near the areas of large head decline. Small adjustments were made in aquifer transmissivity and leakance coefficients of confining units during the calibration of the transient model. These adjustments were tested on the predevelopment model and determined to be reasonable.

The calibrated models were tested to determine the sensitivity of the models to changes in various parameters as measured by head residuals and by total riverflow. Head residuals were most sensitive to changes in aquifer transmissivity (particularly in aquifer outcrop areas), leakance coefficient of confining units, and increases in recharge. Total riverflow was most sensitive to changes in recharge and least sensitive to changes in storage coefficient and leakance coefficient of confining units. The transient model seemed to be equally sensitive or less sensitive to changes in input parameters than the predevelopment model.

The output of the ground-water flow models includes head distributions, water budgets, and refinements of the distributions of recharge, aquifer transmissivity, storage coefficients, leakance coefficients of the confining units, and streambed conductances. The total discharge from the deep ground-water flow system simulated in the transient model for 1982 conditions was $967 \mathrm{ft}^{3} / \mathrm{s}$. Simulated direct recharge in outcrop areas was $793 \mathrm{ft}^{3} / \mathrm{s}$. The remainder of total inflow into the model was from leakage from overlying source-sink beds $\left(30 \mathrm{ft}^{3} / \mathrm{s}\right)$ and inflow across boundaries $\left(34 \mathrm{ft}^{3} / \mathrm{s}\right)$. A net amount of 110 $\mathrm{ft}^{3} / \mathrm{s}$ was derived from storage. Discharge from the aquifer system included $660 \mathrm{ft}^{3} / \mathrm{s}$ to the upper Coastal Plain rivers, $249 \mathrm{ft}^{3} / \mathrm{s}$ to pumped wells, $28 \mathrm{ft}^{3} / \mathrm{s}$ of upward leakage to the overlying source-sink beds, and $30 \mathrm{ft}^{3} / \mathrm{s}$ of outflow across lateral boundaries.

Significant changes in the simulated water budget occurred between predevelopment and 1982. Changes included increases in outflow of $249 \mathrm{ft}^{3} / \mathrm{s}$ to wells, which was balanced by a $110-\mathrm{ft}^{3} / \mathrm{s}$ decrease in storage, $67-\mathrm{ft}^{3} / \mathrm{s}$ decrease in aquifer-to-river discharge, $44-\mathrm{ft}^{3} / \mathrm{s}$ net increase in inflow from source-sinks, and $28-\mathrm{ft}^{3} / \mathrm{s}$ net increase in inflow across boundaries. Water derived from storage, net increases in leakage from overlying sourcesinks, and net increases in boundary flow are the dominant sources of water for pumping centers in the Myrtle Beach area. A decrease in flow to upper Coastal Plain rivers and water derived from storage are the dominant sources of water for upper Coastal Plain pumping centers, such as the city of Florence.

Simulated transmissivity distributions differ little from original estimates because the initial estimates from aquifer-test and specific-capacity data generally were adequate. Transmissivities of all aquifers ranged from less than 1,000 to about $30,000 \mathrm{ft}^{2} / \mathrm{d}$. Leakance coefficients of the confining units were adjusted considerably from initial estimates because there were insufficient data to establish realistic initial estimates and because the model is relatively sensitive to changes in this parameter. On the basis of an assumed average thickness of $100 \mathrm{ft}$ for a confining unit, vertical hydraulic conductivities of the confining units ranged from $6 \times 10^{-7}$ to $3 \times 10^{-2} \mathrm{ft} / \mathrm{d}$. Adjustments in predevelopment values of transmissivity and leakance coefficients to calibrate the transient model were relatively minor. Storage coefficient in confined areas changed somewhat from original estimates of 0.0003 to the final value of 0.0005 and was held constant areally. The updip half of the outcrop area of each aquifer was considered to be unconfined, in response to pumping stress, and assigned a storage coefficient of 0.15 .

\section{SELECTED REFERENCES}

Aucott, W.R., 1988, The predevelopment ground-water flow system and hydrologic characteristics of the Coastal Plain aquifers of South Carolina: U.S. Geological Survey Water-Resources Investigations Report 86-4347, 66 p.

Aucott, W.R.; Davis, M.E.; and Speiran, G.K., 1987, Geohydrologic framework for the Coastal Plain aquifers of South Carolina: U.S. Geological Survey Water-Resources Investigations Report 85-4271, 7 sheets.

Aucott, W.R.; Meadows, R.S.; and Patterson, G.G., 1987, Regional ground-water discharge to large streams in the upper Coastal Plain of South Carolina and parts of North Carolina and Georgia: U.S. Geological Survey Water-Resources Investigations Report $86-4332,28$ p.

Aucott, W.R., and Newcome, Roy, 1986, Selected aquifer test information for the Coastal Plain aquifers of South Carolina: U.S. Geological Survey Water-Resources Investigations Report $86-4159,30 \mathrm{p}$.

Aucott, W.R., and Speiran, G.K., 1985a, Ground-water flow in the Coastal Plain aquifers of South Carolina: Ground Water, v. 23, no. 6 , p. $736-745$.

$1985 \mathrm{~b}$, Potentiometric surfaces of November 1982 and declines in the potentiometric surfaces between the period prior to development and November 1982 for the Coastal Plain aquifers of South Carolina: U.S. Geological Survey Water-Resources Investigations Report 84-4215, 7 sheets. 
1985c, Potentiometric surfaces of the Coastal Plain aquifers of South Carolina prior to development: U.S. Geological Survey Water-Resources Investigations Report $84-4208,5$ sheets.

- 1986, Geohydrology and water quality of the Coastal Plain aquifers of South Carolina, in Proceedings of the Symposium on Ground Water and Environmental Hydrology in South Carolina, South Carolina Department of Health and Environmental Control, Columbia, S.C., 1985: p. 26-50.

Barker, R.A., and Pernik, Maribeth, 1994, Regional hydrology and simulation of deep ground-water flow in the Southeastern Coastal Plain aquifer system in Mississippi, Alabama, Georgia, and South Carolina: U.S. Geological Survey Professional Paper 1410-C, 87 p., 10 pls.

Bloxham, W.M., 1976, Low-flow characteristics of streams in the inner Coastal Plain of South Carolina: South Carolina Water Resources Commission Report 5, 28 p.

1979, Low-flow frequency and flow duration of South Carolina streams: South Carolina Water Resources Commission Report 11, $90 \mathrm{p}$.

1981, Low-flow characteristics of ungaged streams in the Piedmont and lower Coastal Plain of South Carolina: South Carolina Water Resources Commission Report 14, 48 p.

Brown, P.M.; Brown, D.L.; Reid, M.S.; and Lloyd, O.B., Jr., 1979, Evaluation of the geologic and hydrologic factors related to the waste-storage potential of Mesozoic aquifers in the southern part of the Atlantic Coastal Plain, South Carolina, and Georgia: U.S. Geological Survey Professional Paper 1088, 37 p.

Bush, P.W., 1982, Predevelopment flow in the Tertiary limestone aquifer, Southeastern United States-A regional analysis from digital modeling: U.S. Geological Survey Water-Resources Investigations Report 82-905, $41 \mathrm{p}$.

Bush, P.W., and Johnston, R.H., 1988, Ground-water hydraulics, regional flow, and ground-water development of the Floridan aquifer system in Florida and in parts of Georgia, South Carolina, and Alabama: U.S. Geological Survey Professional Paper 1403-C, $80 \mathrm{p}$.

Cahill, J.M., 1982, Hydrology of the low-level radioactive-solid-waste burial site and vicinity near Barnwell, South Carolina: U.S. Geological Survey Open-File Report 82-863, 101 p.

Cederstrom, D.J.; Boswell, E.H.; and Tarver, G.R., 1979, Summary appraisals of the Nation's ground-water resources-South Atlantic-Gulf Region: U.S. Geological Survey Professional Paper 813-0, $35 \mathrm{p}$.

Colquhoun, D.J.; Woollen, I.D.; Van Niewenhuise, D.S.; Padgett, G.G.; Oldham, R.W.; Boylan, D.C.; Bishop, J.W.; and Howell, P.D., 1983, Surface and subsurface stratigraphy, structure and aquifers of the South Carolina Coastal Plain: Columbia, S.C., University of South Carolina, Department of Geology, $78 \mathrm{p}$.

Cooke, C.W., 1936, Geology of the Coastal Plain of South Carolina: U.S. Geological Survey Bulletin 867, 196 p.

Counts, H.B., and Krause, R.E., 1976, Digital model analysis of the principal artesian aquifer, Savannah, Georgia, area: U.S. Geological Survey Water-Resources Investigations Report 76-133, 4 sheets.

Daniels, D.L., and Zietz, Isidore, 1978, Geologic interpretation of aeromagnetic maps of the Coastal Plain region of South Carolina and parts of North Carolina and Georgia: U.S. Geological Survey Open-File Report 78-261, 47 p.

Faye, R.E., and Mayer, G.C., in press, Simulation of ground-water flow in Southeastern Coastal Plain clastic aquifers in Georgia and adjacent parts of Alabama and South Carolina: U.S. Geological Survey Professional Paper 1410-F.

Faye, R.E., and Prowell, D.C., 1982, Effects of Late Cretaceous and Cenozoic faulting on the geology and hydrology of the Coastal
Plain near the Savannah River, Georgia and South Carolina: U.S. Geological Survey Open-File Report 82-156, 73 p.

Freeze, R.A., 1972, Role of subsurface flow in generating surface runoff-1, Base flow contributions to channel flow: Water Resources Research, v. 8, no. 3, p. 609-623.

Freeze, R.A., and Cherry, J.A., 1979, Groundwater: Englewood Cliffs, N.J., Prentice-Hall, 604 p.

Freeze, R.A., and Witherspoon, P.A., 1966, Theoretical analysis of regional groundwater flow-1, Analytical and numerical solutions to the mathematical model: Water Resources Research, v. 2, no. 4, p. $641-656$.

Giese, G.L.; Eimers, J.L.; and Coble, R.W., in press, Simulation of ground-water flow in the Coastal Plain aquifer system of North Carolina: U.S. Geological Survey Professional Paper 1404-M.

Glover, R.E., 1964, The pattern of fresh-water flow in a coastal aquifer, in Sea water in coastal aquifers: U.S. Geological Survey Water-Supply Paper 1613-C, p. 32-35.

Gohn, G.S.; Bybell, L.M.; Smith, C.C.; and Owens, J.P., 1978, Preliminary stratigraphic cross sections of Atlantic Coastal Plain sediments of the Southeastern United States-Cenozoic sediments along the South Carolina coastal margin: U.S. Geological Survey Miscellaneous Field Studies Map MF-1015-B, 2 sheets.

Gohn, G.S.; Christopher, R.A.; Smith, C.C.; and Owens, J.P., 1978, Preliminary stratigraphic cross sections of Atlantic Coastal Plain sediments of the southeastern United States-Cretaceous sediments along the South Carolina coastal margin: U.S. Geological Survey Miscellaneous Field Studies Map MF-1015-A, 2 sheets.

Gohn, G.S.; Higgins, B.B.; Smith, C.C.; and Owens, J.P., 1977, Lithostratigraphy of the deep corehole (Clubhouse Crossroads corehole 1) near Charleston, South Carolina, in Rankin, D.W., ed., Studies related to the Charleston, South Carolina, earthquake of 1886-A preliminary report: U.S. Geological Survey Professional Paper 1028, p. 59-70.

Gohn, G.S.; Smith, C.C.; Christopher, R.A.; and Owens, J.P., 1980, Preliminary stratigraphic cross sections of Atlantic Coastal Plain sediments of the southeastern United States-Cretaceous sediments along the Georgia coastal margin: U.S. Geological Survey Miscellaneous Field Studies Map MF-1015-C, 2 sheets.

Harrigan, J.A., 1985, Water use in South Carolina July-December 1983: South Carolina Water Resources Commission Report 148, $18 \mathrm{p}$.

Hayes, L.R., 1979, The ground-water resources of Beaufort, Colleton, Hampton, and Jasper Counties, South Carolina: South Carolina Water Resources Commission Report 9, $91 \mathrm{p}$.

Hayes, L.R.; Maslia, M.L.; and Meeks, W.C., 1983, Hydrology and model evaluation of the principal artesian aquifer, Dougherty Plain, southwest Georgia: Georgia Geologic Survey Bulletin 97, $93 \mathrm{p}$.

Holzer, T.L., 1984, Ground failure induced by ground-water withdrawal from unconsolidated sediment, in Holzer, T.L., ed., Maninduced land subsidence: Geological Society of America Reviews in Engineering Geology, v. 6, p. 67-105.

Johnston, R.H., and Bush, P.W., 1988, Summary of the hydrology of the Floridan aquifer system in Florida and in parts of Georgia, South Carolina, and Alabama: U.S. Geological Survey Professional Paper 1403-A, 24 p.

Johnston, R.H.; Healy, H.G.; and Hayes, L.R., 1981, Potentiometric surface of the Tertiary limestone aquifer system, Southeastern United States, May 1980: U.S. Geological Survey Open-File Report 81-486, 1 sheet.

Johnston, R.H.; Krause, R.E.; Meyer, F.W.; Ryder, P.D.; Tibbals, C.H.; and Hunn, J.D., 1980, Estimated potentiometric surface for the Tertiary limestone aquifer system, Southeastern United States, prior to development: U.S. Geological Survey Open-File Report 80-406, 1 sheet. 
Krause, R.E., 1982, Digital model evaluation of the predevelopment flow system of the Tertiary limestone aquifer, southeast Georgia, northeast Florida, and southern South Carolina: U.S. Geological Survey Water-Resources Investigations Report 82-173, 27 p.

Krause, R.E., and Randolph, R.B., 1989, Hydrology of the Floridan aquifer system in southeast Georgia and adjacent parts of Florida and South Carolina: U.S. Geological Survey Professional Paper 1403-D, $65 \mathrm{p}$.

Lee, R.W.; DeJarnette, S.L.; and Barker, R.A., 1985, Distribution and altitude of the top of saline ground water in the Southeastern Coastal Plain: U.S. Geological Survey Water-Resources Investigations Report 85-4109, 1 sheet.

LeGrand, H.E., 1955, Brackish water and its structural implications in Great Carolina Ridge, North Carolina: American Association of Petroleum Geologists Bulletin, v. 39, no. 10, p. 2020-2037.

1964, Hydrogeologic framework of the Gulf and Atlantic Coastal Plain: Southeastern Geology, v. 5, no. 4, p. 177-194.

LeGrand, H.E., and Pettyjohn, W.A., 1981, Regional hydrogeologic concepts of homoclinal flanks: Ground Water, v. 19, no. 3, p. 303-310.

Lichtler, W.F., and Aucott, W.R., 1985, South Carolina ground-water resources, in National Water Summary, 1984: U.S. Geological Survey Water-Supply Paper 2275, p. 379-384.

Lofgren, B.E., and Klausing, R.L., 1969, Land subsidence due to ground-water withdrawal, Tulare-Wasco area, California: U.S. Geological Survey Professional Paper 437-B, 103 p.

Lohman, S.W., 1972, Ground-water hydraulies: U.S. Geological Survey Professional Paper 708, $70 \mathrm{p}$.

Lohman, S.W., and others, 1972, Definitions of selected ground-water terms-Revisions and conceptual refinements: U.S. Geological Survey Water-Supply Paper 1988, $21 \mathrm{p}$.

Lonon, G.E.; Burnett, C.B.; and Morris, H.J., 1983, Water use in South Carolina, 1980: South Carolina Water Resources Commission Report 138, $20 \mathrm{p}$.

Maher, J.C., 1971, Geologic framework and petroleum potential of the Atlantic Coastal Plain and Continental Shelf: U.S. Geological Survey Professional Paper 659, 98 p.

Marine, I.W., 1979, Hydrology of buried crystalline rocks at the Savannah River Plant near Aiken, South Carolina: U.S. Geological Survey Open-File Report 79-1544, 160 p.

Marine, I.W., and Siple, G.E., 1974, Buried Triassic basin in the central Savannah River area, South Carolina and Georgia: Geological Society of America Bulletin, v. 85, no. 1, p. 311-320.

Matthews, S.E.; Hester, W.G.; and McFadden, K.W., 1982, Groundwater data for Georgia, 1981: U.S. Geological Survey Open-File Report 82-904, 110 p.

McCartan, Lucy; Lemon, E.M., Jr.; and Weems, R.E., 1984, Geologic map of the area between Charleston and Orangeburg, South Carolina: U.S. Geological Survey Miscellaneous Investigations Map I-1472, 2 sheets.

McDonald, M.G., and Harbaugh, A.W., 1984, A modular threedimensional finite-difference ground-water flow model: U.S. Geological Survey Open-File Report 83-875, $528 \mathrm{p}$.

Miller, J.A., 1986, Hydrogeologic framework of the Floridan aquifer system in Florida and in parts of Georgia, Alabama, and South Carolina: U.S. Geological Survey Professional Paper 1403-B, $91 \mathrm{p}$.

1992, Summary of the hydrology of the Southeastern Coastal Plain aquifer system in Mississippi, Alabama, Georgia, and South Carolina: U.S. Geological Survey Professional Paper 1410-A, 38 p.

Miller, J.A., and Renken, R.A., 1988, Nomenclature of regional hydrogeologic units of the Southeastern Coastal Plain aquifer system: U.S. Geological Survey Water-Resources Investigations Report 87-4202, $21 \mathrm{p}$.
Overstreet, W.C., and Bell, Henry, III, 1965, The crystalline rocks of South Carolina: U.S. Geological Survey Bulletin 1183, 126 p.

Park, A.D., 1980, The ground-water resources of Sumter and Florence Counties, South Carolina: South Carolina Water Resources Commission Report 133, $43 \mathrm{p}$.

1985, The ground-water resources of Charleston, Berkeley, and Dorchester Counties, South Carolina: South Carolina Water Resources Commission Report 139, 146 p.

Peek, H.M., and Register, L.A., 1975, A preliminary report on anomalous pressures in deep artesian aquifers in southeastern North Carolina: North Carolina Department of Natural and Economic Resources Report of Investigation 10, $20 \mathrm{p}$.

Pelletier, A.M., 1985, Ground-water conditions and water-supply alternatives in the Waccamaw capacity use area, South Carolina: South Carolina Water Resources Commission Report 144, $32 \mathrm{p}$.

Poland, J.F., and Davis, G.H., 1969, Land subsidence due to withdrawal of fluids, in Physical hydrogeology: Stroudsburg, Pa., Hutchinson Ross Publishing, p. 384-397.

Prowell, D.C., and O'Connor, B.J., 1978, Belair fault zone-Evidence of Tertiary fault displacement in eastern Georgia: Geology, v. 6, no. 11, p. $681-684$.

Randolph, R.B., and Krause, R.E., 1984, Analysis of the effects of proposed pumping from the principal artesian aquifer, Savannah, Georgia, area: U.S. Geological Survey Water-Resources Investigations Report 84-4064, 26 p.

Rankin, D.W., ed., 1977, Studies related to the Charleston, South Carolina, earthquake of 1886-A preliminary report: U.S. Geological Survey Professional Paper 1028, 204 p.

Renken, R.A., 1984, The hydrogeologic framework for the Southeastern Coastal Plain aquifer system of the United States: U.S. Geological Survey Water-Resources Investigations 84-4243, 26 p.

- in press, Hydrogeology of the Southeastern Coastal Plain aquifer system in Mississippi, Alabama, Georgia, and South Carolina: U.S. Geological Survey Professional Paper 1410-B.

Renken, R.A.; Mahon, G.L.; and Davis, M.E., 1986, Hydrogeology of clastic Tertiary and Cretaceous regional aquifers and confining units in the Southeastern Coastal Plain aquifer system of the United States: U.S. Geological Survey Hydrologic Investigations Atlas 701, 3 sheets.

Sanders, C.L., and Bohman, L.R., 1986, South Carolina surface-water resources, in National water summary 1985: U.S. Geological Survey Water-Supply Paper 2300, p. 413-418.

Selley, R.C., 1980, Ancient sedimentary environments ( 2 d ed.): Ithaca, N.Y., Cornell University Press, $287 \mathrm{p}$.

Siple, G.E., 1946, Progress report on ground-water investigations in South Carolina: South Carolina Research, Planning and Development Board Bulletin 15, $116 \mathrm{p}$.

1957, Ground-water in the South Carolina Coastal Plain: Journal of the American Water Works Association, v. 49, no. 3, p. $283-300$

1959, Guidebook for the South Carolina Coastal Plain field trip of the Carolina Geological Society, Nov. 16-17, 1957: South Carolina State Development Board, Division of Geology Bulletin 24, $27 \mathrm{p}$.

1960, Piezometric levels in the Cretaceous sand aquifer of the Savannah River Basin: Georgia Mineral Newsletter, v. XIII, no. 4 , p. 163-166.

1967, Geology and ground water of the Savannah River Plant and vicinity, South Carolina: U.S. Geological Survey WaterSupply Paper 1841, 113 p.

1975, Ground-water resources of Orangeburg County, South Carolina: South Carolina State Development Board, Division of Geology Bulletin 36, 59 p. 
Sohl, N.E., 1976, Reinstatement of the name Cape Fear Formation in North and South Carolina, in Contributions to stratigraphy: U.S. Geological Survey Bulletin 1422-A, 68 p.

South Carolina Water Resources Commission, 1971, Water use in South Carolina, 1970: South Carolina Water Resources Commission Report 103, 114 p.

1983, South Carolina State water assessment: South Carolina Water Resources Commission Report 140, 367 p.

Speiran, G.K., and Aucott, W.R., 1991, Effects of sediment depositional environment and ground-water flow on the quality and geochemistry of water in aquifers in sediments of Cretaceous age in the Coastal Plain of South Carolina: U.S. Geological Survey Open-File Report 91-202, 80 p.

Stricker, V.A., 1983, Base flow of streams in the outcrop area of southeastern sand aquifer, South Carolina, Georgia, Alabama, and Mississippi: U.S. Geological Survey Water-Resources Investigations Report 83-4106, 17 p.

Stricker, V.A.; Aucott, W.R.; Faye, R.E.; Williams, J.S.; and Mallory, M.J., 1985a, Approximate potentiometric surface for the aquifer unit A2, Southeastern Coastal Plain aquifer system of the United States, prior to development: U.S. Geological Survey WaterResources Investigations Report 85-4019, 1 sheet.

1985b, Approximate potentiometric surface for the aquifer unit A3, Southeastern Coastal Plain aquifer system of the United States, prior to development: U.S. Geological Survey WaterResources Investigations Report 85-4031, 1 sheet.

1985c, Approximate potentiometric surface for the aquifer unit A4, Southeastern Coastal Plain aquifer system of the United States, prior to development: U.S. Geological Survey WaterResources Investigations Report 84-4364, 1 sheet.

Sun, R.J., ed., 1986, Regional Aquifer-System Analysis Program of the U.S. Geological Survey, Summary of projects, 1978-84: U.S. Geological Survey Circular 1002, 263 p.

Toth, J., 1963, A theoretical analysis of groundwater flow in small drainage basins: Journal of Geophysical Research, v. 68, no. 16, p. $\mathbf{4 7 9 5 - 4 8 1 2 .}$
Trescott, P.C., 1975, Documentation of finite-difference model for simulation of three-dimensional ground-water flow: U.S. Geological Survey Open-File Report 75-438, $103 \mathrm{p}$.

Trescott, P.C.; Pinder, G.F.; and Larson, S.P., 1976, Finite-difference model for aquifer simulation in two dimensions with results of numerical experiments: U.S. Geological Survey Techniques of Water-Resources Investigations, book 7, chap. C1, 116 p.

U.S. Environmental Protection Agency, 1986a, Maximum contaminant levels (subpart B of part 141, National revised primary drinkingwater regulations): U.S. Code of Federal Regulations, Title 40, parts 100 to 149, revised July 1, 1986.

_ 1986b, Secondary maximum contaminant levels (section 143.3 of part 143, National secondary drinking-water regulations): U.S. Code of Federal Regulations, Title 40, parts 100 to 149, revised July 1, 1986.

Wait, R.L., and Davis, M.E., 1986, Configuration and hydrology of the pre-Cretaceous rocks underlying the Southeastern Coastal Plain aquifer system: U.S. Geological Survey Water-Resources Investigations Report 86-4010, 1 sheet.

Warren, M.A., 1944, Artesian water in southeastern Georgia: Georgia Geological Survey Bulletin 49A, 83 p.

Weiss, J.S., and Williamson, A.K., 1985, Subdivision of thick sedimentary units into layers for simulation of ground-water flow: Ground Water, v. 23 , no. 6 , p. $767-774$.

Winter, T.C., 1976, Numerical simulation analysis of the interaction of lakes and ground water: U.S. Geological Survey Professional Paper 1001, $45 \mathrm{p}$.

Zack, A.L., 1977, The occurrence, availability, and chemical quality of ground water, Grand Strand area and surrounding parts of Horry and Georgetown Counties, South Carolina: South Carolina Water Resources Commission Report 8, 100 p.

1980, Geochemistry of fluoride in the Black Creek aquifer system of Horry and Georgetown Counties, South Carolina, and its physiological implications: U.S. Geological Survey WaterSupply Paper 2067, $40 \mathrm{p}$.

Zupan, A.W., and Tahirkheli, S.N., 1979, Bibliography and index of South Carolina geology through 1977: South Carolina Geological Survey Bulletin 39, 179 p. 



\section{SELECTED SERIES OF U.S. GEOLOGICAL SURVEY PUBLICATIONS}

\section{Periodical}

Preliminary Determination of Epicenters (issued monthly).

\section{Technical Books and Reports}

Professional Papers are mainly comprehensive scientific reports of wide and lasting interest and importance to professional scientists and engineers. Included are reports on the results of resource studies and of topographic, hydrologic, and geologic investigations. They also include collections of related papers addressing different aspects of a single scientific topic.

Bulletins contain significant data and interpretations that are of lasting scientific interest but are generally more limited in scope or geographic coverage than Professional Papers. They include the results of resource studies and of geologic and topographic investigations, as well as collections of short papers related to a specific topic.

Water-Supply Papers are comprehensive reports that present significant interpretive results of hydrologic investigations of wide interest to professional geologists, hydrologists, and engineers. The series covers investigations in all phases of hydrology, including hydrogeology, availability of water, quality of water, and use of water.

Circulars present administrative information or important scientific information of wide popular interest in a format designed for distribution at no cost to the public. Information is usually of short-term interest.

Water-Resources Investigations Reports are papers of an interpretive nature made available to the public outside the formal USGS publications series. Copies are reproduced on request unlike formal USGS publications, and they are also available for public inspection at depositories indicated in USGS catalogs

Open-File Reports include unpublished manuscript reports, maps, and other material that are made available for public consultation at depositories. They are a nonpermanent form of publication that may be cited in other publications as sources of information.

\section{Maps}

Geologic Quadrangle Maps are multicolor geologic maps on topographic bases in 7.5- or 15-minute quadrangle formats (scales mainly $1: 24,000$ or $1: 62,500$ ) showing bedrock, surficial, or engineering geology. Maps generally include brief texts; some maps include structure and columnar sections only.

Geophysical Investigations Maps are on topographic or planimetric bases at various scales; they show results of surveys using geophysical techniques, such as gravity, magnetic, seismic, or radioactivity, which reflect subsurface structures that are of economic or geologic significance. Many maps include correlations with the geology.

Miscellaneous Investigations Series Maps are on planimetric or topographic bases of regular and irregular areas at various scales; they present a wide variety of format and subject matter. The series also includes 7.5-minute quadrangle photogeologic maps on planimetric bases that show geology as interpreted from aerial photographs. Series also includes maps of Mars and the Moon.
Coal Investigations Maps are geologic maps on topographic or planimetric bases at various scales showing bedrock or surficial geology, stratigraphy, and structural relations in certain coalresource areas.

Oil and Gas Investigations Charts show stratigraphic information for certain oil and gas fields and other areas having petroleum potential.

Miscellaneous Field Studies Maps are multicolor or blackand-white maps on topographic or planimetric bases for quadrangle or irregular areas at various scales. Pre-1971 maps show bedrock geology in relation to specific mining or mineral-deposit problems; post-1971 maps are primarily black-and-white maps on various subjects such as environmental studies or wilderness mineral investigations.

Hydrologic Investigations Atlases are multicolored or blackand-white maps on topographic or planimetric bases presenting a wide range of geohydrologic data of both regular and irregular areas; principal scale is $1: 24,000$, and regional studies are at $1: 250,000$ scale or smaller.

\section{Catalogs}

Permanent catalogs, as well as some others, giving comprehensive listings of U.S. Geological Survey publications are available under the conditions indicated below from the U.S. Geological Survey, Information Services, Box 25286, Federal Center, Denver, CO 80225. (See latest Price and Availability List.)

"Publications of the Geological Survey, 1879-1961" may be purchased by mail and over the counter in paperback book form and as a set of microfiche.

"Publications of the Geological Survey, 1962-1970" may be purchased by mail and over the counter in paperback book form and as a set of microfiche.

"Publications of the U.S. Geological Survey, 1971-1981" may be purchased by mail and over the counter in paperback book form (two volumes, publications listing and index) and as a set of microfiche.

Supplements for $1982,1983,1984,1985,1986$, and for subsequent years since the last permanent catalog may be purchased by mail and over the counter in paperback book form.

State catalogs, "List of U.S. Geological Survey Geologic and Water-Supply Reports and Maps For (State)," may be purchased by mail and over the counter in paperback booklet form only.

"Price and Availability List of U.S. Geological Survey Publications," issued annually, is available free of charge in paperback booklet form only.

Selected copies of a monthly catalog "New Publications of the U.S. Geological Survey" are available free of charge by mail or may be obtained over the counter in paperback booklet form only. Those wishing a free subscription to the monthly catalog "New Publications of the U.S. Geological Survey" should write to the U.S. Geological Survey, 582 National Center, Reston, VA 20192.

Note-Prices of Government publications listed in older catalogs, announcements, and publications may be incorrect. Therefore, the prices charged may differ from the prices in catalogs, announcements, and publications. 